
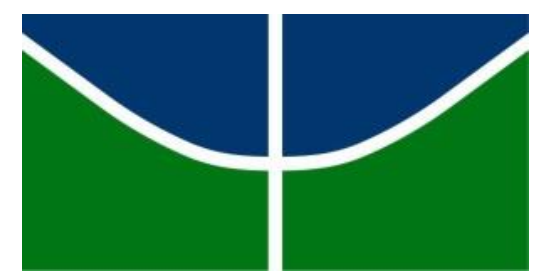

UNIVERSIDADE DE BRASÍLIA INSTITUTO DE FÍSICA

PROGRAMA DE PÓS-GRADUAÇÃO DE MESTRADO PROFISSIONAL EM ENSINO DE FÍSICA

MESTRADO NACIONAL PROFISSIONAL EM ENSINO DE FÍSICA

PROPOSTA DE UMA METODOLOGIA PARA ABORDAGEM DA CONSERVAÇÃO DO MOMENTO ANGULAR NO ENSINO MÉDIO

Jefferson Maia da Costa 

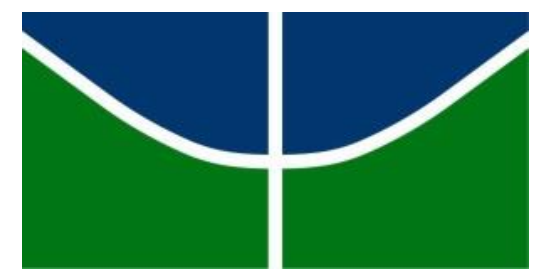

UNIVERSIDADE DE BRASÍLIA

INSTITUTO DE FÍSICA

PROGRAMA DE PÓS-GRADUAÇÃO DE MESTRADO PROFISSIONAL EM ENSINO DE FÍSICA

MESTRADO NACIONAL PROFISSIONAL EM ENSINO DE FÍSICA

\section{PROPOSTA DE UMA METODOLOGIA PARA ABORDAGEM DA CONSERVAÇÃO DO MOMENTO ANGULAR NO ENSINO MÉDIO}

Jefferson Maia da Costa

Dissertação realizada sob a orientação da Professora Doutora Maria de Fátima da Silva Verdeaux e apresentada à banca examinadora do Programa de Mestrado Nacional em Pesquisa e Ensino de Física (MNPEF), polo Universidade de Brasília, como requisito parcial para a obtenção do título de mestre em Ensino de Física, na área de concentração "Física na Educação Básica".

BRASÍLIA - DF

2015 
C387p Costa, Jefferson Maia da

Proposta de uma metodologia para abordagem da conservação do momento angular no ensino médio / Jefferson Maia da Costa; orientadora Maria de Fátima da Silva Verdeaux - Brasília: UnB, 2015.

$112 \mathrm{p}$.

Dissertação (Mestrado - Mestrado Profissionalizante em Ensino de Física) - Universidade de Brasília, 2015.

1. Ensino de física. 2. Momento angular. 3. Livro didático. 4. Ensino médio. I. Verdeaux, Maria de Fátima da Silva, orient. II. Proposta de uma metodologia para abordagem da conservação do momento angular no ensino médio. 


\section{FOLHA DE APROVAÇÃO}

JEFFERSON MAIA DA COSTA

\section{PROPOSTA DE UMA METODOLOGIA PARA ABORDAGEM DA CONSERVAÇÃO DO MOMENTO ANGULAR NO ENSINO MÉDIO}

Dissertação apresentada à banca examinadora como requisito parcial à obtenção do Título de Mestre em Ensino de Física - Área de Concentração "Física na Educação Básica" pelo Programa de Pós-Graduação de Mestrado Profissional em Ensino de Física

Aprovada em 15/12/2015

BANCA EXAMINADORA

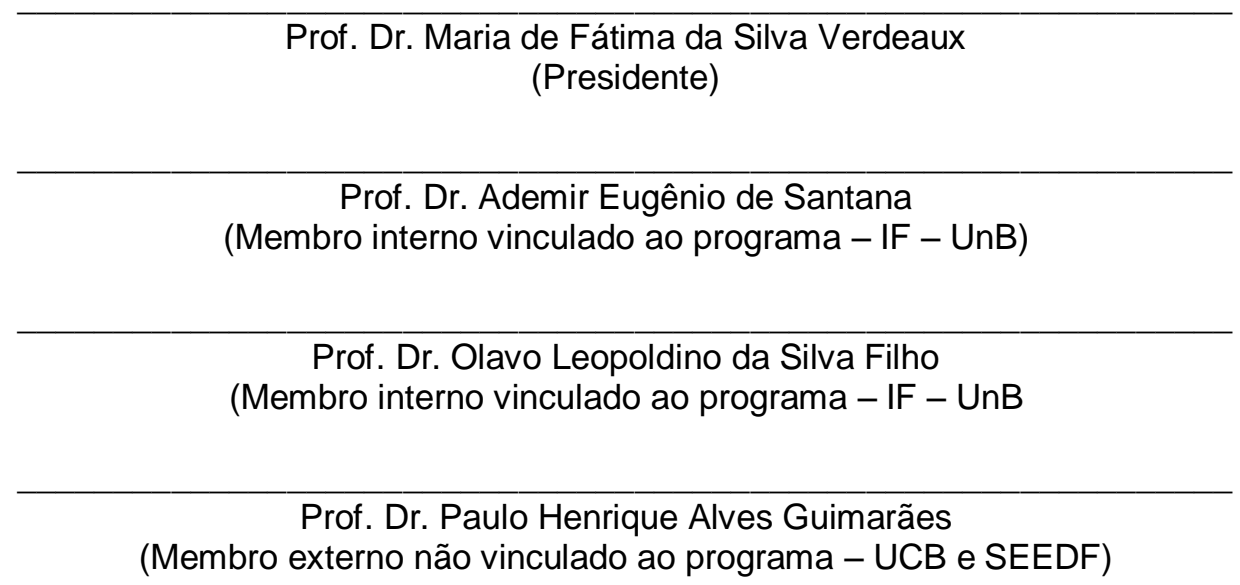


Dedico esse trabalho ao querido Professor Pierluigi Piazzi, falecido em março deste ano. Seu desejo de colaborar para o aperfeiçoamento da educação no Brasil deixaram-me marcas inextinguíveis. Sua passagem fez grande diferença! Boa viagem, Professor Pier!

"O que precisamos é parar de procurar novas maneiras de ensinar e resgatar as velhas formas de aprender."

Professor Pier 


\section{Agradecimentos}

À CAPES, pelo apoio financeiro por meio da bolsa concedida.

À Sociedade Brasileira de Física (SBF) pela idealização do MNPEF.

Ao Instituto de Física da UnB.

À SEEDF pela concessão da licença de afastamento para estudos.

Aos meus pais, Antônio Costa e Francisca Vilany, pela educação que me propiciaram, da qual me orgulho e de todas as maneiras e modos como conduziram a minha formação como filho, como ser humano. Nossas idas às livrarias no Gonzaga, em Santos, amados pai e mãe, sempre foram os melhores passeios!

Ao meu irmão Jonatas, ainda que mais novo do que eu, um grande exemplo! Seus conselhos e olhares críticos sempre construtivos me encorajam a seguir em frente. Sabes que sem você eu não teria chegado até aqui.

À minha irmã Veruska, que me alegra, me diverte! Como você me faz rir! Tenho enormes saudades de quando éramos mais novos e de quantas vezes eu ouvi seus conselhos. Ajudou-me, mais que todos, a conhecer a mim mesmo!

Aos meus dois cunhados, Jonas e Renata. Também meus irmãos e conselheiros, sempre solidários e atenciosos comigo. Também ganhei com o casamento de vocês com meus dois irmãos. Sejam sempre muito bem vindos!

Ao meu querido tio Luís! Também obrigado pela paciência e pelo carinho de sempre. Ícone de admiração, alegria e perseverança para mim. Afortunado sou eu por poder contar com você!

A todos os meus amados e valorosos amigos, aqui representados por Juliana Ferreira, Rafael Oliveira, Érica Nóbrega, Ananda Borges, Edmilson Perousa, Cézar Teixeira que suportam a todo o momento as minhas constantes ausências, mas que nunca deixaram de estar ao meu lado. Apesar de solitário, saibam que os levo sempre comigo, meus queridos!

A você, Felippe Maciel, amado amigo! Mesmo de longe, continua sempre presente em minha vida. Para além de toda a nossa salutar e profícua convivência em todos esses anos, muito obrigado pelos comentários e sugestões desta diligência. Sua análise, como sempre, precisa, incisiva e plena! 
A todos da equipe Reciclagem Matemática! Obrigado pela paciência e apoio nestes últimos meses em que estivemos separados. Agradeço a compreensão diante de minha necessária dedicação à conclusão desta tarefa rumo à almejada outorga de qualificação. Não se preocupe, humanidade! Ano que vem estaremos juntos de novo!

Aos amigos do mestrado! Queridos, perdoem-me as notas de Termodinâmica... Mas foi divertido! A minha lembrança e meus sentimentos àqueles mais próximos: André Periquito, Bruno Gomides, Leandro Vaz, José Maria, Marcos Antônio Pequi, Rendisley Aristóteles. A todos os demais, irradio a mesma emoção, o mesmo sentimento!

Aos sujeitos de minha pesquisa. Que participaram da investigação, opinando, criticando e apontando incorreções ou imperfeições em minha proposta. Agradeço por doarem parte de seu tempo e enriquecerem este projeto.

À minha querida professora e orientadora de mestrado Maria de Fátima Verdeaux! Como você foi paciente! Obrigado pelas inúmeras palavras de incentivo e as reprimendas. Agradeço o carinho, a confiança e o reconhecimento de minhas qualidades e potenciais. Em memória à música de Leandro e Leonardo: separando e voltando, a gente sempre seguiu andando entre tapas e beijos! Mas foi ótimo!

A Deus! A Ele, a honra, a glória e o louvor. 
Epígrafe

"Se você pensa que pode ou se pensa que não pode, de qualquer forma você está certo."

Henry Ford 


\title{
RESUMO
}

PROPOSTA DE UMA METODOLOGIA PARA ABORDAGEM DA CONSERVAÇÃO DO MOMENTO ANGULAR NO ENSINO MÉDIO

\author{
Jefferson Maia da Costa
}

Orientadora:

\section{Professora Doutora Maria de Fátima da Silva Verdeaux}

Dissertação de Mestrado submetida ao Programa de Pós-Graduação da Universidade de Brasília no Curso de Mestrado Profissional de Ensino de Física (MNPEF), como parte dos requisitos necessários à obtenção do título de Mestre em Ensino de Física, na área de concentração "Física na Educação Básica".

Neste trabalho, apresento uma investigação acerca das abordagens didático-pedagógicas do conteúdo da Conservação do Momento Angular contido nos livros didáticos circunscritos ao Plano Nacional do Livro Didático (PNLD) de 2015, bem como discuto os artigos de periódicos científicos da área de educação e do ensino da física relacionados ao tema. Consciente de que tal conteúdo é pouco ou nada abordado na maioria dos livros didáticos do ensino médio, encaminho uma proposta de ensino que tem como objetivo minimizar o hiato existente entre o tema em discussão e outros tantos costumeiramente integrados ao currículo do ensino médio. A partir dos resultados de entrevistas realizadas com professores da escola pública, que analisaram e avaliaram a proposta didática, encerro destacando as contribuições do produto gerado e refletindo sobre as adequações a serem realizadas junto à proposta, em face aos aspectos estruturantes do contexto do componente curricular de física na educação básica pública e demais perspectivas.

Palavras-chave: Ensino de física, Momento angular, Livro didático, Ensino médio.

\author{
BRASÍLIA - DF
}

2015 


\begin{abstract}
A PROPOSAL FOR A METHODOLOGY OF THE CONSERVATION OF ANGULAR MOMENTUM APPROACH IN HIGH SCHOOL

Jefferson Maia da Costa

Supervisor:

Maria de Fátima da Silva Verdeaux, Professor Doctor

Abstract of master's thesis submitted to Programa de Pós-Graduação da Universidade de Brasília no Curso de Mestrado Profissional de Ensino de Física (MNPEF), in partial fulfillment of the requirements for the degree Mestre em Ensino de Física, "Física na Educação Básica" concentration area.
\end{abstract}

In this paper, we present an investigation about the didactic and pedagogical approaches of the Angular Momentum Conservation contained in textbooks circumscribed to the Plano Nacional do Livro Didático (PNLD 2015) and discuss the scientific journal articles in the field of education and physics education related to the topic. Aware that such content is little or nothing addressed in most teaching high school books, I forward a proposal for a school that aims to minimize the gap between the topic under consideration and many others routinely integrated into the high school curriculum. Based on the results of interviews with teachers of public schools, which analyzed and evaluated the didactic proposal, I close highlighting the contributions of the generated product and reflecting on the adjustments to be carried out by the proposal, given the structural aspects of the curricular component of context of physics at basic public education and other prospects.

Keywords: Physics education, Angular momentum, Textbook, High school.

BRASÍLIA - DF

2015 


\section{Lista de ilustrações}

Figura 1.1. Capa de livro - Física: Ciência e Tecnologia ............................................. 21

Figura 1.2. Capa de livro - QUANTA FÍSICA..................................................... 26

Figura 1.3. Tabela de correspondências entre rotação e translação.............................. 30

Figura 3.1. Harlem Globetrotter ajuda garota a equilibrar a bola de basquete............... 47

Figura 3.2. Segways da polícia militar de Pernambuco. .......................................... 48

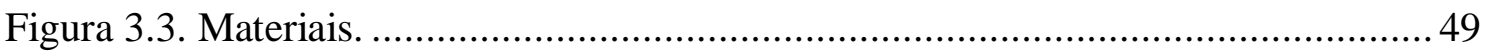

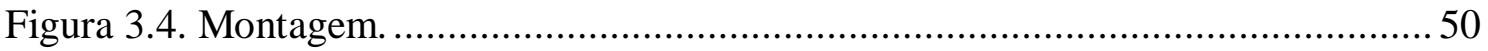

Figura 3.5. Borracha girando em movimento circular em plano paralelo ao chão......... 50

Figura 3.6. Borracha girando em movimento circular em plano perpendicular ao chão.51

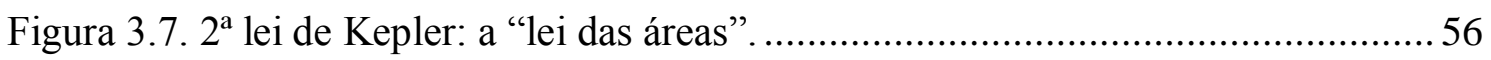

Figura 3.8. Patinadora em rodopio em torno de si mesma. .......................................... 62

Figura 3.9. Tipo de acrobacia realizada por um praticante. ...................................... 63

Figura 3.10. Experiência da cadeira giratória com os alteres..................................... 64

Figura 3.11. Momentos de inércia de alguns sólidos homogêneos. ............................. 67

Figura 3.12. Objeto rígido em rotação em torno de um eixo que passa pelo ponto $O \ldots . .70$

Figura 3.13. "Gire uma bola manipulando a gravidade e a velocidade." .73

Figura 4.1. Objeto suspenso por outro ao percorrer trajetória circular sobre uma mesa. 90 


\section{Sumário}

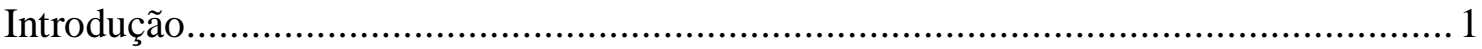

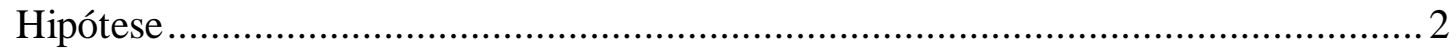

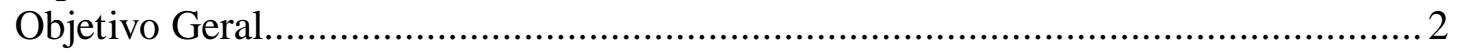

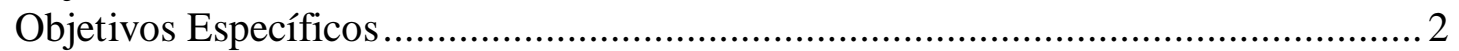

Capítulo $1 \mathrm{O}$ Ensino da Conservação do Momento Angular ........................................ 3

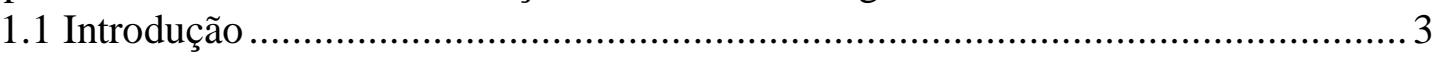

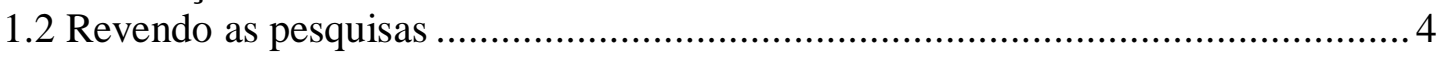

1.3 Conservação do Momento Angular: o que dizem os livros didáticos .................. 13

1.3.1 O não-lugar do conteúdo de conservação do momento angular em livros

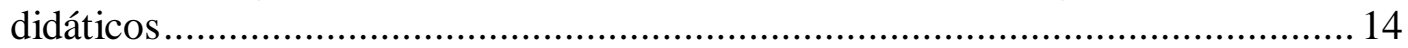

1.3.2 O lugar do conteúdo de conservação do momento angular em livros didáticos

Capítulo $2 \mathrm{O}$ professor-pesquisador em física e a (real) necessidade de fundamentos teórico-pedagógicos em sua formação .............................................................. 32

Capítulo 3 Considerações teórico-metodológicas e os intervenientes da pesquisa ........ 37

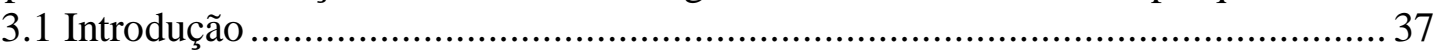

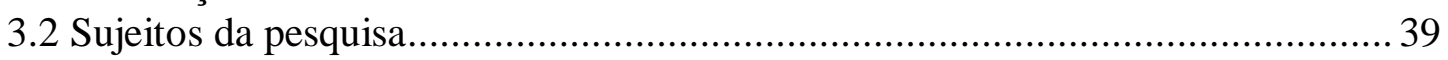

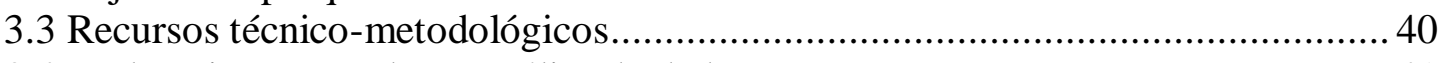

3.4 Esclarecimentos sobre a análise de dados .................................................... 41

3.5 Proposta pedagógica em conservação do momento angular: desenvolvimento e

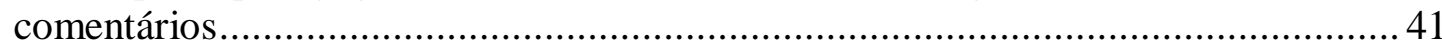

3.6 Proposta pedagógica em conservação do momento angular: texto didático ........ 47 Capítulo 4 Refletindo sobre o ensino de Conservação do Momento Angular: críticas e

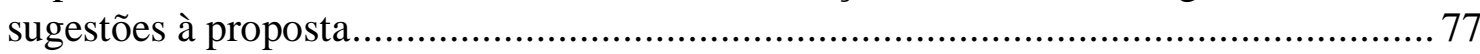

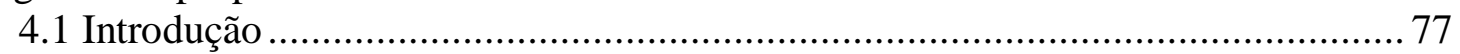

4.2 Sobre o potencial pedagógico do produto educacional analisado e avaliado ....... 77

4.3 Sobre o rigor técnico matemático e conceitual e as possibilidades de inovação pedagógica a partir da proposta ...................................................................... 81

4.4 Sobre a natureza de a proposta ter características de roteiro fechado e com pouco espaço de intervenção do professor. ................................................................... 88 4.5 Sobre as motivações do professor com relação ao uso da proposta educacional em face às possíveis dificuldades em aplicá-lo em sala de aula ou equivalente............. 92

Considerações finais e perspectivas futuras .......................................................... 96

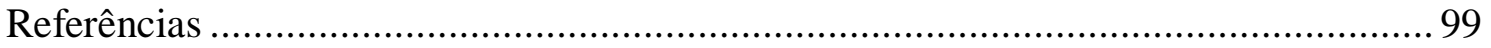




\section{Introdução}

O presente estudo teve duplo objetivo. Primeiro, investigar as abordagens didático-pedagógicas de ensino a respeito do conteúdo de Conservação do Momento Angular (CMA) expressos em livros didáticos de física do ensino médio da educação básica brasileira. Segundo, enriquecido dos resultados obtidos por essa análise, elaborar uma proposta didática de ensino em CMA.

Para isso, procurei do ponto de vista metodológico, realizar um recorte em torno de análise bibliográfica específica de livros didáticos de física circunscritos ao Plano Nacional do Livro Didático (PNLD) de 2015. Outros livros foram incorporados à análise crítica para a discussão em torno dos conteúdos supracitados. Ademais, artigos de periódicos científicos da área de educação e do ensino de física foram incluídos como fundamentos teóricos que auxiliaram minhas análises e reflexões. A proposta pedagógica elaborada tornou-se, ao longo da pesquisa, objeto de estudo e foi analisada e avaliada por um grupo de professores de física com ampla experiência no magistério da educação básica. $\mathrm{O}$ crivo desses professores diante da proposta subsidiou os resultados da pesquisa.

A propósito de justificação do estudo, apresentam-se três motivos que, traduzindo-se em hipóteses e que, articulados entre si, oferecem subsídios importantes para sustentar uma argumentação em torno da relevância e da perspectiva educacional da presente pesquisa. O primeiro é o de apontar como uma lei da mecânica clássica - o CMA - é sumariamente secundarizada do ensino em relação a outras leis sem razão aparente. O segundo motivo é o da percepção de potencial desse conteúdo em muitos contextos de realidade e que justificariam inclusive a sua própria importância. Por fim, o terceiro motivo se apresenta como aquele que, em face à marginalização desse conteúdo, pode ascender este estudo a uma perspectiva educacional de proposição pedagógica alternativa às abordagens de ensino desse assunto em livros didáticos ou mesmo nas salas de aula, acaso o professor que a estuda pretenda aplicá-la.

Este trabalho, organizado em formato de dissertação, dispõe inicialmente de um capítulo de revisão de literatura. Nele são apresentados alguns estudos acadêmicos que tematizaram e objetivaram investigar o ensino de CMA. Parte importante da pesquisa, qual seja aquela que procura proceder à análise de livros didáticos do PNLD também fazem parte deste capítulo. Na sequência, o capítulo 2 aborda de forma crítica a identificação do referencial teórico e marco pedagógico do estudo. Nesse momento são 
discutidas questões pertinentes à formação do professor pesquisador em ensino de ciências por meio de um mestrado profissional e é onde se declara a aprendizagem significativa de David Ausubel como o referencial teórico do produto educacional elaborado. A dissertação segue com o seu terceiro capítulo circunscrevendo os aspectos metodológicos do estudo. Esse capítulo, além dos elementos de natureza procedimental e instrumental da pesquisa, torna evidente a proposta pedagógica e os comentários do seu processo de desenvolvimento e elaboração. O capítulo 4 oferece os resultados e discussão. Nele são analisados os conteúdos extraídos de entrevistas com os professores de física que analisaram e avaliaram a proposta didática. O texto se encerra refletindo sobre as dificuldades de se promover adequações à proposta em face aos aspectos estruturantes do contexto do componente curricular de física na educação básica pública e outras perspectivas de qualificação da proposta.

\section{Hipótese}

Pensar que uma lei da mecânica clássica é sumariamente secundarizada em relação a outras leis sem razão aparente. Visa-se, portanto, perceber o potencial desse conteúdo em muitos contextos de realidade e que justificariam inclusive a sua própria importância e aplicabilidade.

\section{Objetivo Geral}

Investigar as abordagens didático-pedagógicas de ensino a respeito do conteúdo de Conservação do Momento Angular expressos em livros didáticos de Física do Ensino Médio da educação básica brasileira e assim subsidiar uma proposta pedagógica que potencialize o seu uso didático junto aos estudantes.

\section{Objetivos Específicos}

- Identificar e analisar as abordagens didático-pedagógicas do ensino do conteúdo Conservação do Momento Angular em livros didáticos de física da educação básica;

- Concorrer para a produção de novas abordagens didático-pedagógicas de ensino de física, especificamente na temática da Conservação do Momento Angular. 


\section{Capítulo 1 \\ O Ensino da Conservação do Momento Angular}

\subsection{Introdução}

O mote do presente estudo toma como objeto o ensino do conteúdo da conservação do momento angular (CMA) no ensino médio da escola básica. Parto da hipótese de que este campo de conhecimento da Física, embora seja normalmente abordado no ensino superior, não se apresenta com a mesma ênfase na educação básica. A escassa literatura cientifica específica sobre o ensino da conservação do momento angular no âmbito da escola, parece dar indícios de que minha hipótese pode ser confirmada. Tal objeto de pesquisa é pouco explorado e tal exiguidade do interesse acadêmico talvez reflita sua ausência como um conteúdo importante a ser abordado no ensino médio por meio de propostas pedagógicas explícitas em livros didáticos.

Observando estes aspectos é que o capítulo de revisão de literatura deste trabalho foi elaborado. Dividido em dois subcapítulos, inicialmente são apresentados os estudos e pesquisas que tematizam o ensino de conservação do momento angular em propostas pedagógicas e, na sequência, são analisados os livros didáticos, em especial aqueles que integram o Plano Nacional do Livro Didático de 2015 (PNLD), disponibilizados pelo governo federal aos alunos das redes públicas escolares, indicando aqueles que oferecem o conteúdo de conservação do momento angular como possibilidade de ensino na escola brasileira,

O conteúdo da seção que aborda as pesquisas sobre o ensino da conservação do momento angular foi organizado a partir do conjunto de estudos disponíveis no banco de dados da CAPES e tomando como descritores os termos "ensino de física", "ensino de ciências" e "conservação do momento angular". A busca agregou artigos, dissertações e teses. Somaram-se à pesquisa bibliográfica, trabalhos apresentados e publicados em anais de congressos científicos de ensino de ciências e ensino de física. Embora amplos os meios de procura de estudos científicos relacionados ao tema de minha pesquisa, os resultados trouxeram poucas referências: quatro artigos e uma dissertação. Se por um lado, a ausência de estudos específicos dificulta a produção de um arcabouço de ideias e percepções sobre o estado da arte do objeto, por outro, torna evidente o quão é necessário avançar as investigações sobre esse mesmo objeto. Foi o que procurei fazer nesta revisão. 
A segunda seção desta revisão de literatura foi produzida a partir da análise dos livros didáticos que constam no PNLD, totalizando 14 obras. Destes, apenas dois livros abordam de forma contundente o conteúdo de conservação do momento angular, sendo estes, objetos de minha discussão à luz das ideias propositivas que, mais adiante na realização da pesquisa de campo, tentei evidenciar. Outrossim, com o auxílio do documento orientador do PNLD de 2015, apresento sinteticamente aspectos descritivos e a visão geral das propostas didático-pedagógicas de todos os livros aprovados pelo programa.

\subsection{Revendo as pesquisas}

Como já mencionado, o quantitativo de estudos e pesquisas que evidenciam de forma específica o ensino de CMA na educação básica não é tão expressivo na literatura científica. De todo modo, o conjunto de referências analisadas demonstram preocupações com as formas alternativas de ensino da CMA. Aspectos didáticos revelam questões interessantes e que podem conduzir a algumas transformações metodológicas nos aportes do assunto em livros didáticos. A questão da ludicidade e a experimentação prática envolvendo a conservação do momento angular parece ser uma tendência dos estudos em torno de propostas pedagógicas.

A preocupação de compreender processos de aprendizagem significativa em ensino de Física conduziram Carvalho e Villani (1996) a produzirem estudo que objetivou evidenciar a evolução das ideias de estudantes secundarista com relação à apropriação do conteúdo de conservação em mecânica. Do ponto de vista metodológico, foram reunidos seis estudantes, que tinham entre quinze e vinte e dois anos, a fim de realizar entrevistas com base em orientações didáticas, “(...) visavam simultaneamente levantar as ideias dos estudantes e modificá-las na direção do conhecimento científico" (CARVALHO; VILLANI, 1996, p.77). As entrevistas didáticas produziram os dados da pesquisa e, segundo os autores, a realização delas implicavam que os estudantes tomassem contato com o conteúdo ora de forma autônoma, ora orientados pela própria entrevistadora motivados pela realização de experiências com colisões. Porém, sempre a partir de algum trabalho didático, seja na forma oral e por tarefas ou na produção e vivência de experiências pedagógicas. A análise dos dados partiu de duas categorias que os autores identificaram para pensar a evolução das representações mentais dos estudantes. Estas, eles chamaram de representações fenomenológicas e representações formais. A primeira correspondia aos conhecimentos espontâneos dos estudantes e 
baseados em senso comum; o segundo se relacionava aos conhecimentos teóricos demonstrados pelos estudantes a partir da introdução de conhecimentos dos princípios de conservação no diálogo com a entrevistadora. Segundo os autores, a existência de preconcepções na mente do estudante para compreender e interpretar fenômenos do cotidiano é identificada como uma das principais causas da resistência e dificuldade na aquisição do conhecimento científico (VIENNOT apud ARRUDA; VILLANI, 1994). Tais concepções prévias eram utilizadas pelos entrevistados na tentativa de explicar certas regularidades nos eventos observados. Sem ignorar tais aspectos, torna-se possível detectar as mudanças conceituais por parte dos estudantes e se tais modificações aproximam-se ou se afastam do caminho pretendido na apresentação e elaboração da visão científica.

Na pesquisa, Carvalho e Villani (1996) evidenciaram que as representações mentais dos estudantes no processo de ensino-aprendizagem em conteúdos da conservação mecânica, não dependiam de forma contundente da natureza do experimento. A ênfase interpretativa dos autores no que tange a evolução dos estudantes foi determinada, em parte, pela ação da entrevistadora e suas intervenções didáticas. Dessa forma, a conclusão da pesquisa incide diretamente sobre a importância de ações didáticas ressignificadas e transformadas no que se refere ao ensino dos princípios de conservação. Nesse sentido, advogam os autores que

[...] pelo menos no Brasil, o ensino das leis de conservação no segundo grau, quando acontece, consegue atingir, no máximo, a fase de coleção de conhecimentos, considerada pelos docentes como conclusão satisfatória do processo de aprendizagem sobre o tema colisões e princípios de conservação. Consequentemente torna-se urgente pesquisar, de um lado, formas de atualização dos professores para que tomem consciência da fragilidade dos sucessos alcançados pelos estudantes nesta fase e, de outro lado, estratégias didáticas concretas para favorecer $\mathrm{o}$ processo de reorganização das representações formais dos estudantes. (CARVALHO; VILLANI, 1996, p.87 - grifo dos autores).

Tal coleção de conhecimentos considerada como satisfatória, de acordo com Carvalho e Villani (1996), serve de alerta para a presente pesquisa, cujo objetivo final é a elaboração de um material de suporte para o ensino da CMA que visa o entendimento de uma terceira lei mecânica de conservação que dialogue com as duas anteriores.

Em trabalhos recentes, novas estratégias didáticas para o ensino de CMA demonstram tender para propostas que enfatizam as demonstrações experimentais e 
projetos lúdicos como formas de ensino contextualizados e mais significativas aos estudantes. O estudo de Würs (2012), por exemplo, procede nesta perspectiva.

A partir de uma vivência de prática pedagógica no ensino superior, especificamente em disciplina orientada para a formação inicial de professores de Física, Würz (2012) relata a experiência de um projeto pedagógico com o objetivo de ensinar o tema Momento Angular por meio de experimentos lúdicos. Defende que a ludicidade fomentada em objetos de ensino pode despertar o interesse dos alunos para a aprendizagem da Física. Dessa forma, criar-se-ia um ambiente propício ao desenvolvimento de competências requeridas pelos Parâmetros Curriculares Nacionais $(\mathrm{PCN}+)$.

Würz (2012), professor da disciplina Projeto Integrador, componente curricular do curso de Licenciatura em Ciências da Natureza com Habilitação em Física, do Instituto Federal de Santa Catarina do Instituto Federal de Santa Catarina, conduziu um grupo de acadêmicos a pensar e elaborar experimentos pedagógicos para avaliar o método de ensino acerca do assunto Momento Angular. Os acadêmicos posteriormente realizaram um exercício pedagógico de ensino em uma turma de ensino médio de uma escola estadual da cidade de Jaraguá do Sul (SC) utilizando como instrumento didático os experimentos anteriormente elaborados, os quais utilizam uma plataforma giratória, o pião e o ioiô. Na sequência e com o objetivo de investigar a prática pedagógica baseada em experimentos lúdicos, aplicou-se um questionário à guisa de avaliar o método de ensino com base nas aprendizagens e na satisfação dos alunos. Somaram-se aos dados aspectos observados durante as aulas e perguntas direcionadas aos acadêmicos.

Segundo Würz (2012), os resultados apontaram para aspectos que indicam um potencial promissor do uso de experimentos pedagógicos lúdicos como ferramentas de ensino para o tema de momento angular. A apropriação de como identificar o momento angular chegou a 93\% dos alunos da turma e, mesmo questões relacionadas ao tema de trigonometria, obteve $90 \%$ dos alunos com êxito de aprendizagem do conteúdo. O nível de satisfação no que se refere à aceitação dos alunos ao método de uso de experimentos lúdicos também se mostrou excelente, uma vez que $90 \%$ dos alunos avaliaram como ótima as apresentações dos acadêmicos. Würz (2012) conclui que um trabalho diferenciado, por meio do uso de experimentos lúdicos, certamente pode colaborar para a melhoria do processo de ensino e aprendizagem da Física na escola.

A despeito dos resultados positivos enaltecidos pelo autor, é importante relativizar a superficialidade da exposição no artigo em questão. As informações de 
natureza metodológica são pouco expostas, fato que prejudica a compressão do contexto no qual a investigação ocorreu. Algumas informações do questionário aplicado demonstram um nível muito simplista no que corresponde a suposta aprendizagem dos alunos que se relacionavam com os experimentos. Por exemplo, no caso do ioiô, o aluno deveria julgar certo ou errado a seguinte afirmativa: "As energias envolvidas no funcionamento do ioiô, são as energias CINÉTICA e POTENCIAL" (WÜRZ, 2012, p.76). Informações teóricas eram apresentadas aos alunos durante as aulas com relação à brincadeira do ioiô. Observando a questão, é procedente a crítica de que se trata de uma questão de cunho meramente conteudista. Dessa forma, parece questionável a indicação de que a brincadeira (ou o lúdico) determinou a aprendizagem em função da resposta correta. No caso, bastaria ao aluno se recordar da informação trazida durante o momento da aula na qual se brincou com o ioiô. Acrescente-se também a ênfase por parte do autor na maior satisfação prazerosa por parte dos alunos por conta das brincadeiras envolvendo o ioiô e a plataforma giratória, o que acaba por enfatizar em demasia aspectos recreativos da experimentação em detrimento da apropriação do conhecimento científico pretendido. Por fim, convém ressaltar que podem ser encontrados alguns erros conceituais físicos e matemáticos ao longo da exposição textual.

Entretanto, urge destacar a pesquisa no que se refere à investigação de propostas pedagógicas em ensino superior que procuram discutir e experimentar metodologias didáticas renovadas. Nesse aspecto, o trabalho de Würz (2012) contribui no sentido de pensar o ensino de física na escola, especificamente, no âmbito do conteúdo de conservação do momento angular, assunto raro de ser estudado e, frequentemente, sequer comentado no ensino básico.

Ainda que o alvo para a confecção e implementação de minha pesquisa, bem como o produto educacional por ela gerado seja o público brasileiro, considerei conveniente e de ganho conceitual e vivencial comentar e analisar dois trabalhos publicados na Revista Latino-Americana de Física Educação (LAJPE). Na mesma direção de Würz (2012) segue o trabalho de Morales (2009a), embora configurado em contexto diferente e de forma distinta do ponto de vista metodológico. Para Morales (2009a) o currículo atual orienta o ensino a não permanecer apenas focado em aspectos do conteúdo. Ao contrário, deve integrar o desenvolvimento de habilidades aos quais os estudantes possam analisar as características interdisciplinares do conhecimento e suas possibilidades contextualizadas à realidade. Para o autor, uma excelente estratégia 
didática a fim de situar o ensino a partir de uma aprendizagem significativa é fomentar o uso de experimentos por meio de pesquisas, projetos ou trabalhos práticos. Segundo Morales (2012), os processos físicos podem ser mais bem compreendidos quando observados por meio de experimentos.

Orientando por estas ideias, Morales (2009a) conduziu uma pesquisa que objetivava investigar a experiência pedagógica desenvolvida com uma turma de ensino superior a partir de uma proposta de ensino baseada na construção de projeto. O projeto, por sua vez, orientava a produção de um experimento na temática da conservação do momento angular e foi desenvolvido por etapas ao longo de um semestre de ensino. $\mathrm{O}$ autor defende a perspectiva de ensino baseada em projeto se fundamentando na corrente construtivista de ensino segundo alguns autores da educação e psicologia da aprendizagem, quais sejam Jean Piaget, Lev Vigostsky e John Dewey. Ademais, menciona as ideias de Ausebel no sentido de justificar suas intenções no que tange a possibilidade de uma prática pedagógica que crie um ambiente de aprendizagem significativa aos estudantes. Morales (2009a) argumenta a favor do ensino por projetos e identifica seis aspectos positivos que envolvem a aprendizagem nesta perspectiva: a) contribui para preparar melhor os estudantes para a vida profissional; b) induz uma maior motivação de professores e estudantes; c) estabelece uma conexão entre a aprendizagem, a universidade e a realidade; d) aumenta as habilidades sociais e comunicativas; e) desenvolve habilidades para a solução de problemas; f) permite aos estudantes demonstrarem seus potenciais individuais e coletivos a partir o trabalho colaborativo.

O artigo descreve os processos metodológicos de ensino a partir da elaboração de projetos de estudantes pertencentes ao segundo semestre de treinamento em ciências básicas da Faculdade de Engenharia da Universidade Manuela Beltrán (Bogotá Colômbia). Demonstra, por meio de tabelas, a organização em cronogramas de etapas de elaboração e acompanhamento desse processo por parte do professor. Os projetos foram produzidos em grupos de 3 a 4 estudantes. Os resultados do artigo foram construídos observando a análise das avaliações de cada etapa do processo. As etapas se dividiam da seguinte forma: a) apresentação oral das ideias iniciais da proposta de projeto; b) entrega escrita de um pré-projeto; c) apresentação oral do projeto; d) entrega escrita do projeto; e) apresentação oral do experimento; f) produção de relatório final (artigo). Observando estas etapas, Morales (2009a) indica que os estudantes percorreram um processo de desenvolvimento que evidenciou a necessidade de se 
incorporar aprendizagens que iam além do próprio experimento, como por exemplo, as habilidades relacionadas aos momentos de apresentação oral e de normas técnicas de relatórios escritos. Com relação aos conhecimentos teóricos da física necessários a elaboração do experimento, uma parte significativa dos estudantes foi capaz de reconhecerem variáveis e constantes dentro dos modelos físicos envolvidos nos experimentos; puderam se envolver de forma protagonista com os experimentos desenvolvidos; usaram estatísticas e teorias de cálculo a fim de tornar compreensíveis aspectos do experimento.

Na mesma vertente do trabalho anterior, Morales (2009b) descreve a construção de um protótipo de baixo custo que permitia verificar a lei de conservação do momento angular. Segundo o autor, a dinâmica rotacional - assunto dificilmente abordado no ensino médio - suscita muitas dúvidas no aprendizado para os estudantes e dificuldades no ensino para os professores. A intenção na construção e funcionamento do protótipo, bem como sua relação com a cinemática e dinâmica rotacional, é a de superar tais obstáculos. Outros conceitos correlacionados também podem ser explorados com o mesmo aparato experimental, tais como o momento de inércia de um sistema físico, o torque de uma força, relações entre variáveis cinemáticas lineares e angulares e aplicação do princípio fundamental da dinâmica para translações e rotações. $\mathrm{O}$ aparato construído consiste de uma peça em forma de ' $T$ ' cujo eixo gira mediante um fio conectado a um peso suspenso, montado sobre uma polia. Há dois tubos cilíndricos, inicialmente colocados próximos ao eixo da peça em cada um dos braços. Com o giro da peça em ' $\mathrm{T}$ ' provocado pelo torque do fio conectado ao peso que cai pela roldana, os tubos cilíndricos, por inércia - ou pela força centrífuga - afastam-se para as extremidades de cada braço. Concêntrica ao eixo da peça em ' $\mathrm{T}$ ' é colocada uma roda dentada que permite medir a velocidade angular do conjunto que gira ${ }^{1}$. Sem os tubos cilíndricos ou se os mesmos estivessem fixos em uma única posição nos braços da peça em formato de ' $\mathrm{T}$ ', a sua velocidade angular cresceria linearmente com a queda do peso. Isso de fato acontece até o momento que, vencendo o atrito inicial, os tubos deslizam para as extremidades dos braços da peça em ' $T$ ', modificando, portanto o momento de inércia da peça, quando então novas medições da velocidade angular são realizadas. $\mathrm{O}$

\footnotetext{
${ }^{1} \mathrm{O}$ artigo original possui figuras ilustrativas do protótipo. Além disso, a referência [8] deste artigo conduz o leitor a um site que auxilia na visualização da montagem do experimento. Sugiro também que para melhor compreender o experimento de Morales (2009b), vale checar o vídeo "Richard Garriott Space Video Blog: Angular Momentum" no YouTube, onde o autor do vídeo realiza experiência similar. Disponível em: <https://www.youtube.com/watch?v=C8kCKPo5lf0 >. Acesso em: $1^{\circ}$ de outubro de 2015.
} 
conjunto gira aproximadamente num movimento circular uniformemente variado em ambas as situações. Entretanto, com a mudança de posição dos tubos cilindros nos braços da peça em ' $T$ ', modifica-se o seu momento de inércia e, consequentemente, a velocidade angular do conjunto. Por meio das medições aferidas, confecciona-se um gráfico da velocidade angular com relação ao tempo, o que permite determinar a aceleração angular do conjunto, antes e depois dos tubos atingirem as extremidades da peça em ' $T$ '. Ao comparar os produtos entre o momento de inércia e a velocidade angular, antes e depois, verifica-se uma diferença de 5,3\%, considerada como aceitável pelo autor do artigo, concluindo-se, portanto, que o momento angular do conjunto não é alterado. Morales (2009b) finaliza o artigo citando que o mesmo aparato experimental tem sido utilizado com sucesso para ajudar na compreensão e verificação dos conceitos relacionados à conservação do momento angular em cursos de mecânica na Universidad de Manuela Beltrán e na Escuela Colombiana de Ingeniería em Bogotá, Colômbia.

Embora o trabalho de Morales (2009b) tenha uma importância demonstrativa prática da conservação do momento angular, a própria construção do protótipo não é explorada. Seria perfeitamente possível fazer uso de um protótipo já pronto. O experimento pode ser aplicado inclusive no ensino médio, embora a sua construção pareça ser irrelevante no que diz respeito aos objetivos pedagógicos. Não há muita clareza na exposição da montagem e funcionamento do aparato que é descrito de forma superficial. Na confecção dos gráficos das velocidades angulares em função do tempo, convém ressaltar que o intervalo de tempo em que os tubos cilindros deslocam-se do centro para a periferia seria desprezado. Confesso ter ficado confuso ao tentar identificar quais seriam a aceleração angulares iniciais e finais indicadas na tabela e utilizadas no cálculo do momento de inércia. Todos esses detalhes, ainda que importantes, podem não ter sido levados a cabo no artigo original em função do espaço disponível da publicação. Curiosamente, os aspectos físicos explorados no aparato experimental e relacionados à conservação do momento angular, assemelham-se bastante com a experiência didática que serve de motivação introdutória em minha proposta pedagógica.

Com relação à temática do presente estudo apresenta-se a investigação de Silva (2012). Fruto de pesquisa de mestrado, Silva (2012) mostra-se preocupada com as mais recentes diretrizes curriculares para o ensino de Física no Brasil expressas no PCN+ mas, segundo a autora, não presente no trabalho cotidiano dos docentes na escola: 
Embora esses documentos tenham sido elaborados para facilitar a implantação de um trabalho interdisciplinar, existe uma distância muito grande entre o "dizer" e o "fazer", ou seja, na prática escolar ainda se vive o ensino vertical, em que cada professor trata de sua área de forma individual e sem conexões entre as disciplinas. (SILVA, 2012, p.2).

Seguindo a linha crítica em sua análise da conjuntura atual do ensino de Física, Silva (2012) lembra alguns conteúdos que possuem potencial de contextualização na realidade, mas são completamente negligenciados quando se opera o currículo escolar, como é o caso do ensino do Momento Angular e Torque. Segundo ela, sua importância é destacada visto que são conhecimentos representativos de diversos fenômenos físicos, principalmente na Astronomia e na Mecânica Quântica. A autora menciona, mesmo de forma breve, a ausência destes conteúdos em livros didáticos, aspecto corroborado por mim e discutido na próxima seção deste capítulo.

Baseando-se nesta justificativa, Silva (2012) objetivou seu estudo procurando compreender como ocorrem as práticas pedagógicas de professores de Física quando ensinam o conteúdo de Momento Angular e Torque nas escolas. Para isso, fez uso de amplo questionário sobre os procedimentos metodológicos de ensino e a intencionalidade dos professores de escolas públicas estaduais do município de Maringá - PR. O questionário, que provia 11 questões, foi respondido por 19 professores. As informações do perfil dos professores foram apresentadas de forma objetiva no questionário. As informações sobre a natureza da prática pedagógica dos professores, com ênfase nos desafios/dificuldades do ensino, foram obtidas a partir de questões abertas no questionário.

Quanto ao perfil dos professores, os dados demonstraram que um terço deles não possuía licenciatura em Física, fato que ratifica a lacuna de professores para o ensino deste componente curricular na escola, ou, a ausência de políticas públicas de educação que incentive a contratação de profissionais por meio de concurso. Além disso, os resultados da pesquisa apontaram que as dificuldades dos professores quando tematizam Momento Angular e Torque nas aulas se devem a motivos externos e "alheios" a eles. De forma geral, três grandes motivos depõem contra a eficácia do ensino deste conteúdo para os respondentes: a) a escassez de tempo pedagógico no componente curricular de Física em relação a grande quantidade de conteúdos previstos no programa de ensino; b) a falta de infraestrutura da escola e condições de trabalho para explorar 
contextualizações na realidade específicas a este conteúdo; c) crescente desinteresse por parte dos estudantes para aprender conteúdos de Física na escola.

Em face aos resultados, a reflexão de Silva (2012, p.67) sobre tais aspectos evidenciados é que “[...] o problema na realidade é a estrutura de organização escolar, uma vez que é necessário que o planejamento dos professores esteja de acordo com o calendário escolar e ainda que o docente saiba dosar com coerência os conteúdos que ele pretende lecionar". Ademais, “[...] a dificuldade em selecionar os temas pode estar ligada à dificuldade que os próprios professores têm ou tiveram para compreender os conteúdos". Tal reflexão corrobora a hipótese de Morales (2009b) ao propor à construção do protótipo para verificação da lei de conservação do momento angular.

A despeito das instigantes informações produzidas na pesquisa, em minha opinião, mostram-se rasas as discussões levantadas pela autora no estudo em questão. Aglutinar as dificuldades do ensino do Momento Angular e Torque nos termos das condições objetivas do trabalho docente na escola escamoteiam os processos criativos possíveis de serem empreendidos por professores e estudantes. Tratando-se de conhecimentos reconhecidamente presentes no cotidiano, os recursos materiais não determinam a possibilidade de vários exemplos que podem ser apresentados ou mesmo vivenciados por meio de práticas experimentais, como fizeram Würz (2012) e Morales (2009a, 2009b), aqui lembrados. A organização pedagógica a fim de atender o "programa curricular" disposto no calendário escolar lembra-me da permanente prática pedagógica de professores orientados a uma tecnocracia do trabalho não condizente com as novas diretrizes ( $\mathrm{PCN}+)$. Obviamente que a "culpa" não se dirige ao professor, senão a todo o sistema educacional levado a cabo pela instituição escolar. A propósito disso, uma hipótese não fomentada por Silva (2012), mas que me parece relevante observando os dados da pesquisa, é a premente necessidade de formação continuada dos professores investigados. Nesse sentido, há de se concordar com a autora no que se refere às dificuldades dos professores com relação ao domínio de conteúdo especifico ao Momento Angular e Torque bem como os processos educativos possíveis de tratamento de tal temática na escola.

O que pese estas críticas, o trabalho de Silva (2012) se tornou fundamental na composição da presente pesquisa, em função do interesse comum em investigar aspectos da prática pedagógica do ensino do conteúdo da Conservação do Momento Angular na escola. Enquanto a autora procurou dar voz aos professores no sentido de entender as dificuldades do ensino, minha proposta procurou basear-se na expressão 
deste conhecimento nas orientações didáticas de apoio em livros didáticos para na sequência, experimentar uma proposta pedagógica alternativa. Os resultados da observação realizada em livros didáticos é o tema da próxima seção desta revisão.

\subsection{Conservação do Momento Angular: o que dizem os livros didáticos}

O Programa Nacional do Livro Didático (PNLD) destaca-se como o programa mais antigo do Ministério da Educação no que diz respeito à política de distribuição de livros didáticos aos estudantes de escolas públicas. Desde 1929, o Estado brasileiro possui um órgão específico para organizar e gerir a produção de livros didáticos. Ao longo dos anos o programa foi várias vezes reformado e acompanhou as tendências do pensamento pedagógico brasileiro (FREITAG et. al., 1993). A partir de 1985, o projeto é institucionalizado com a denominação de PNLD e, desde então, vem se aperfeiçoando em compasso às novas diretrizes da educação brasileira. Em 2001, um incremento de recursos vindos do Fundo Nacional de Desenvolvimento da Educação (FNDE) fez avançar consideravelmente o programa. Reestrutura-se a distribuição de livros no ensino fundamental, médio e na educação de jovens e adultos bem como se aperfeiçoa a avaliação dos livros selecionados com o apoio das universidades federais brasileiras. Mais recentemente, o PNLD introduziu a possibilidade das editoras produzirem, de forma complementar aos livros, DVDs com tecnologias educacionais como jogos eletrônicos, vídeos, animações, imagens e outras inovações pedagógicas.

Tendo em vista a importância política do PNLD para a educação pública brasileira, tomei o guia do PNLD/2015 para o ensino de Física como documento norteador das referências analisadas desta pesquisa e que, a seguir, são discutidas nesta revisão, observando a presença ou não do conteúdo de Conservação do Momento Angular (CMA). Apenas dois livros que compões o PNLD apresentaram uma proposta de desenvolvimento do conteúdo-objeto desta investigação. Tratam-se dos livros Física - Ciência e Tecnologia, de Carlos Magno A. Torres, Nicolau Gilberto Ferraro, Paulo Antonio de Toledo Soares e Paulo Cesar Martins Penteado e Quanta Física, de Carlos Aparecido Kantor, Lilio Alonso Paoliello Júnior, Luís Carlos de Menezes, Marcelo de Carvalho Bonetti, Osvaldo Canato Júnior e Viviane Moraes Alves, os quais foram mais bem explorados nesta revisão. Tais livros compõem parte importante de meu objetivo, pois alguns de seus elementos ou, a opção didático-pedagógica de abordagem de seus autores, constituem influência relevante no que correspondeu a minha elaboração de 
proposição didática investigada na pesquisa de campo. Os demais livros que também foram revistos, embora não contemplem de forma contundente o conteúdo de conservação do momento angular, são apresentados de maneira sintética logo à partida.

A partir do próximo parágrafo, a narrativa segue características lineares com relação à descrição sumária dos livros. Embora haja perda de um caráter articulado na leitura, entendo que desta forma preserva-se a intenção de realçar a ausência ou a presença do conteúdo-objeto da pesquisa. Os títulos de cada obra são destacados em negrito e sua descrição e análise se configuram em parágrafo único. Isso contribui para rápida localização de cada livro analisado.

\subsubsection{O não-lugar do conteúdo de conservação do momento angular em livros didáticos}

A coleção Compreendendo a Física, de Alberto Gaspar, 2ª edição, 2013, da editora Ática, composta por livro impresso e digital, possui três volumes que se destacam pelo desenvolvimento de um grande conjunto de conteúdos priorizando, no seu desenvolvimento, o formalismo matemático. Embora estejam presentes, a contextualização e a abordagem interdisciplinar não são elementos principais de organização didático-pedagógica da obra, que prefere uma distribuição mais tradicional dos conteúdos. Apesar do conteúdo do primeiro volume caracterizar-se por uma abordagem bastante abrangente, o autor preferiu tratar exclusivamente das leis de conservação da energia mecânica e da quantidade de movimento. Em unidade específica do primeiro volume, intitulada Leis de Conservação, os conceitos e tratamento formal das duas leis de conservação são desenvolvidos ao longo de quatro capítulos. Oportunidade que poderia ser igualmente aproveitada no tocante à lei da conservação do momento angular, com a inserção de um ou dois capítulos que tratassem do tema. $\mathrm{O}$ conceito de torque (momento de uma força) é abordado em capítulo de outra unidade, no tratamento exclusivo do equilíbrio do corpo rígido, em conformidade à organização tradicional dos conteúdos de boa parte dos livros do ensino médio.

A obra Física, de Alysson Ramos Artuso e Marlon Wrublewski, editora Positivo, $1^{\text {a }}$ edição de 2013, é composta por três volumes. Cada volume é dividido em quatro unidades, sugerindo a distribuição de abordagem dos conteúdos em quatro bimestres ou períodos do ano letivo. A busca pela contextualização é uma característica marcante da obra; a diversidade de linguagem e o uso de objetos de ensino/aprendizagem estimulam a reflexão sobre situações cotidianas e como os 
conteúdos da Física foram desenvolvidos, aprimorados ou transformados ao longo da história. A obra, assim, aponta para um aprendizado progressivo dos conteúdos. Cada capítulo inicia-se por uma discussão do tema que será tratado usando situações do cotidiano e/ou de aplicações tecnológicas, procurando também avaliar os conhecimentos prévios dos alunos. A Unidade 3 do volume 1, intitulada Leis da conservação, desenvolve os conceitos de energia e trabalho; impulso e quantidade de movimento, cada qual em um capítulo onde são tratadas as leis de conservação da energia mecânica e da quantidade de movimento (momento linear). A mesma Unidade 3 poderia contemplar a existência de um terceiro capítulo e, de forma equivalente, desenvolver os conceitos de torque e quantidade de movimento angular (momento angular) da mesma forma que o fazem os dois capítulos já existentes. O conceito de torque ou momento de uma força é tratado na unidade seguinte que analisa apenas situações de equilíbrio em Estática.

A coleção Física - Conceitos e Contextos: Pessoal, Social, Histórico, de Maurício Pietrocola, Alexander Pogibin, Renata de Andrade e Talita Raquel Romero, da editora FTD, $1^{\text {a }}$ edição, 2013, é composta de três volumes, divididos em unidades e capítulos. A proposta da coleção é a de estimular os alunos a partir de situaçõesproblema. A fim de criar e estabelecer um diálogo com as situações-problema apresentadas, a obra traz atividades compostas de experimentos práticos e materiais multimídia que busquem facilitar o entendimento e a compreensão da física envolvida. Tais situações buscam potencializar a formação de um indivíduo autônomo, capaz de tomar decisões num nível de conhecimento que lhe permita relacionar o mundo teórico lido nos livros com o mundo prático e vivencial do seu cotidiano. Diferente da organização normalmente adotada em textos de física do ensino médio, os conteúdos de energia mecânica e quantidade de movimento são abordados no volume 2 da coleção. Conquanto ambos os assuntos sejam desenvolvidos ao longo de quatro capítulos em sequência, todos eles fazem parte de uma mesma unidade sob o título de Energia. Ou seja, como um capítulo subordinado a uma unidade maior, a lei de conservação da quantidade de movimento parece receber igual conotação, dando-se a impressão de uma particularização ou uma subseção do tema mais geral Energia. Sabemos que isso não é verdade. A obra não aborda a conservação do momento angular e o conceito de momento de uma força é analisado no capítulo 8, Equilíbrio de Forças, Unidade 3, pertencente ainda ao primeiro volume da coleção. 
A obra Física, de José Roberto Castilho Piqueira, Wilson Carron e José Osvaldo de Souza Guimarães, da editora Ática, $1^{\text {a }}$ edição de 2013, constituída de livros impressos e digitais, é composta de três volumes, cada um deles divididos em quatro unidades subdividas em capítulos e tópicos. São exploradas questões numa perspectiva problematizadora no início de cada unidade e que conduzem à necessidade de se estudar a física relacionada a elas. Situações que se relacionam com o papel do cidadão no que diz respeito ao trabalho, bem como outras dimensões na vida de cada um, contribuem para o aprofundamento das discussões dos conceitos físicos envolvidos. Presença marcante da história, tecnologia e sociedade, a abordagem interdisciplinar e contextualizada, além da diversidade encontrada nas atividades propostas, favorecem a autonomia do estudante ao promover seu contato com situações que envolvem interpretações de informações e tomada de decisões para além daquelas propostas nos textos didáticos. Nesse caráter interdisciplinar, os temas relacionados à energia e ao meio ambiente recebem especial destaque na obra como um todo. A coleção ainda disponibiliza vinte e oito Objetos Educacionais Digitais que compõem o livro digital. A Unidade 3 do volume 1, chamada Energia e as Leis de Conservação, é composta de dois capítulos específicos que versam sobre a lei de conservação da energia mecânica e lei da conservação da quantidade de movimento, além de um terceiro capítulo intitulado $\mathrm{O}$ Sistema Solar e a Terra, que não trata especificamente de leis de conservação. Os autores não fazem referência ao conceito de momento angular. $\mathrm{O}$ torque ou momento de uma força é abordado na unidade seguinte, em capítulo sobre a Estática do corpo rígido, como é de praxe.

A coleção Física Aula por Aula de Claudio Xavier e Benigno Barreto, editora FTD, $2^{a}$ edição, 2013, é composta por três volumes organizada em unidades e subdividida em capítulos. Partindo dos conhecimentos prévios dos alunos, o texto resgata as experiências vivenciadas por eles no sentido de reconhecer a física como instrumento útil no exercício da cidadania. A contextualização é um ponto forte da obra, explorada por meio de textos objetivos, exercícios, esquemas e materiais digitais que buscam expandir os significados dos conhecimentos físicos e suas conexões com outras áreas do saber. A multiplicidade de atividades e suas relações atuam no sentido da formação de um pensamento crítico, aprimoramento da capacidade de argumentação e tomada de decisões mediante situações-problema. Outro ponto de destaque na obra são as referências às construções de conhecimentos da física introduzidas em cada um dos volumes da coleção. A Unidade 5 do volume 1 é composta de dois capítulos com os 
títulos Energia e Trabalho e Conservação da Quantidade de Movimento. A unidade sob o título de Energia e Leis de Conservação da Dinâmica dá especial destaque ao conceito de energia e, embora o título faça referência geral às leis de conservação, não é mencionada a lei da conservação do momento angular, sugerindo que aquelas seriam as duas únicas leis de conservação da dinâmica. Os autores dedicam um capítulo da Unidade 7 para o tratamento do momento de uma força, sob o título de Equilíbrio de um Corpo Extenso.

A coleção Física Contexto \& Aplicações de Antônio Máximo e Beatriz Alvarenga, $1^{\text {a }}$ edição, 2013, da Editora Scipione é composta de três volumes divididos em unidades que, por sua vez, são subdivididos em capítulos. Um destaque da obra é clareza e simplicidade na exposição dos conteúdos que são discutidos sem erros conceituais, mas sem exageros no formalismo matemático. Os autores acreditam que o nível de profundidade dos assuntos abordados deve ser compatível com o que se espera da formação do estudante secundarista. Dessa forma também possibilita ao docente a escolha dos assuntos a serem abordados e discutidos, bem como diferentes níveis de aprofundamento na exposição de cada um deles. A apresentação dos conteúdos é feita de forma tradicional dando-se destaque às contextualizações e aplicações tecnológicas. Experiências lúdicas e que podem ser confeccionadas com materiais caseiros e baratos ilustram e demonstram conceitos debatidos em cada unidade. O enfoque Ciência, Tecnologia e Sociedade não aparenta ser muito explorado na obra. Objetos educacionais digitais também fazem parte do livro digital e são distribuídos de maneira uniforme ao longo dos três volumes da coleção. Apesar da Unidade 4 ter como parte do título as leis de conservação (Leis de conservação - Fluidos), os autores preferiram não abordar também a lei de conservação do momento angular, tratando exclusivamente da energia mecânica e da quantidade de movimento (momento linear). O conceito de momento de uma força por sua vez é tratado em apêndice em outra unidade e ao final do capítulo onde são abordadas a primeira e terceira leis de Newton.

A coleção Física de José Roberto Bonjorno, Regina Azenha Bonjorno, Valter Bonjorno, Clinton Marcico Ramos Eduardo Prado e Renato Casemiro, 2a edição, 2013, da editora FTD é composta de três volumes estruturados em unidades divididas em capítulos. A contextualização do conteúdo apresentada a partir das leituras de introdução dos capítulos e em textos complementares é um dos pontos a ser assinalado na obra. Tanto os conteúdos quanto a forma de apresentação dos mesmos segue a estrutura tradicional dos livros mais antigos do ensino médio. Procurando muitas vezes 
aproximar-se da linguagem do aluno, os textos da coleção introduzem os assuntos a partir de situações vivenciais dos estudantes. Exemplos de aplicações tecnológicas da Física aparecem com frequência oferecendo ao professor oportunidades para discussões com enfoque ciência, tecnologia e sociedade. A história da ciência é explorada nos finais de muitos capítulos da coleção. As duas leis de conservação tradicionalmente apresentadas nos livros de ensino médio são tratadas na mesma Unidade IV, intitulada Dinâmica. Entretanto, apenas seções de dois capítulos; a saber, Capítulo 9: Força e Movimento e Capítulo 10: Energia, são dedicadas às discussões da conservação da energia mecânica e da quantidade de movimento. De fato, o texto não destaca as leis de conservação mecânicas como tópicos especiais. Cada seção trata-as apenas como aspectos relacionados às leis de Newton e ao conceito de energia. A obra não faz referência ao conceito de momento angular e o momento de uma força é assunto do Capítulo 12 sob o título de Equilíbrio de um Corpo, pertinente à Unidade V.

A coleção Física Interação e Tecnologia de Aurélio Gonçalves Filho e Carlos Toscano, $1^{\text {a }}$ edição, 2013, da editora Leya é composta de três volumes divididos apenas em capítulos. Ao final de cada capítulo são apresentadas sugestões de projetos interdisciplinares entre a Física e outras áreas do conhecimento. Os capítulos são independentes, o que permite ao professor, a escolha de uma sequência que melhor se adapte ao seu planejamento pedagógico considerando características peculiares de cada turma. Não obstante, os conteúdos são organizados de forma recursiva, possibilitando que as ideias possam ser retomadas mais adiante com diferentes níveis de profundidade. O tratamento contextualizado dos temas permite a visão da física como construção humana e social e sua relação com o cotidiano. Distinções sobre conceitos científicos e o senso comum também são exploradas. Fugindo bastante do modelo tradicional, os autores optam por apresentar o conceito de força logo no capítulo inicial da obra para em sequência tratar os conceitos de impulso e quantidade de movimento que culminarão nas leis fundamentais de mecânica, tratadas no capítulo seguinte. As cinemáticas escalar e vetorial foram separadas em dois capítulos complementares ao final do primeiro volume. Os autores não relacionam os conceitos de quantidade de movimento e energia mecânica à duas leis de conservação de forma explícita. Também não há referências ao momento angular, tampouco à sua conservação. O torque ou momento de uma força é tratado em capítulo à parte sobre estática, como de costume.

A coleção Física para o Ensino Médio de Luiz Felipe Fuke e Kazuhito Yamamoto da Editora Saraiva, $3^{\text {a }}$ edição, 2013, é composta por três volumes 
constituídos por unidades separadas em capítulos. No início de cada Unidade são apresentados textos problematizadores que contextualizam os temas a serem tratados ao longo de cada capítulo. Os assuntos são desenvolvidos procurando oferecer um painel histórico do desenvolvimento da Física na abordagem Ciência, Tecnologia e Sociedade. A obra privilegia um currículo focado nos conceitos fundamentais, permitindo liberdade de trabalho em diferentes sequências didáticas bem como diferentes níveis de aprofundamento dos conteúdos. A seleção de exercícios e problemas propostos ao final de cada capítulo, segundo os autores, visa à sedimentação e ampliação dos conhecimentos objetivados no lugar de exercícios com excessiva carga matemática. São também propostas atividades práticas de fácil execução e que fornecem possibilidades de exploração. Não há destaque para as leis de conservação do momento linear e da energia mecânica. Os conceitos de quantidade de movimento e energia são abordados em dois capítulos pertinentes à Unidade 3: Dinâmica. O conceito de torque ou momento de uma força é explorado em situações de equilíbrio estático na unidade seguinte em capítulo que trata da estática dos corpos rígidos. A conservação do momento angular não é alvo de discussão da coleção, o que parece contraditório ao fato dos autores reconhecerem a necessidade de conhecimento e formação do aluno do ensino médio no nível de exigência das provas oficiais que também contemplam o conteúdo-objeto desta pesquisa.

A coleção Física de Ricardo Helou Doca, Newton Villas Bôas e Gualter José Biscuola da editora Saraiva, $2^{a}$ edição de 2013, composta por três volumes, encontra-se dividida em unidades que são subdivididas em capítulos que especificam e detalham os assuntos setorizados em cada unidade. Em toda a obra, a física é tratada com profundidade e rigor matemático, às vezes, além daquele geralmente observado no nível de ensino médio. Entretanto, isso de forma alguma prejudica na compreensão e clareza dos conceitos na exposição dos autores. A multiplicidade de discursos desenvolvidos ao longo do texto é bem articulada, favorecendo a retomada dos conteúdos de forma recursiva entre os três volumes da coleção. Nesse aspecto, algo que chama a atenção é o tempo necessário para o desenvolvimento da diversidade de conteúdos que são tratados com profundidade. Cabe ao professor dosar e escolher aqueles assuntos de maior relevância caso não se disponha de carga horária suficiente para o bom desenvolvimento de cada assunto. A história da ciência não é um ponto de grande destaque da obra, e embora não haja um direcionamento tácito do enfoque Ciência, Tecnologia e Sociedade, muitos textos podem ser utilizados com esse propósito, ao longo da coleção. As leis de 
conservação da energia mecânica e da quantidade de movimento são tratadas como assuntos específicos pertinentes à Unidade 2, intitulada Dinâmica. O conceito de torque é desenvolvido no capítulo de título Estática dos Sólidos, na Unidade 3. Apesar de boa parte do conteúdo da física ser tratado pelos autores com densidade e abrangência, não são feitas referências à conservação do momento angular no primeiro volume.

A coleção Ser Protagonista - Física de Ana Fukui, Madson de Melo Molina e Venerando Santiago de Oliveira da editora SM, $2^{\text {a }}$ edição de 2013, é composta de três volumes estruturados em unidades. A obra segue a tendência tradicional tanto na organização de capítulos como no desenvolvimento dos assuntos dentro deles, valorizando os conceitos e definições formais. Cada unidade inicia-se com a apresentação de imagens acompanhadas de um texto motivacional que problematiza e contextualiza o assunto que será tratado. A interdisciplinaridade e a relação Ciência, Tecnologia e Sociedade também estão presentes, embora não sejam pontos de destaque da coleção. Apesar das propostas de discussão no uso dos conhecimentos científicos em algumas seções dos capítulos nem sempre apresentarem-se articuladas com as temáticas trabalhadas, há uma grande quantidade de exemplos aplicações e uso da tecnologia no dia-a-dia, bem como a de exercícios propostos que auxiliam na compreensão e fixação dos conceitos abordados. Ao seguir um modelo bastante tradicional, não há destaque especial para as leis de conservação da energia e da quantidade de movimento que aparecem como conteúdos integrados a dois capítulos da unidade 2, de título Dinâmica. O conteúdo da conservação do momento angular não é objeto de estudo da coleção e o conceito de momento de uma força é estudado em situações de equilíbrio em unidade distinta, intitulada Estática, como é feito de forma habitual.

A obra Conexões com a Física de Gloria Martini, Walter Spinelli, Hugo Carneiro Rei e Blaidi Sant'Anna da editora Moderna, 2a edição de 2013, é composta de três volumes, organizadas em unidades e capítulos. Como outras obras já descritas, a discussão e apresentação dos conteúdos e conceitos abordados em cada unidade são motivadas por uma imagem associada a uma questão introdutória de uma situaçãoproblema contextualizada que visa explorar os conhecimentos prévios dos alunos para, a seguir, abordar o tema do ponto de vista da Física. Embora a obra também seja estruturada de forma tradicional, os autores procurem estabelecer articulações entre tópicos que estejam relacionados, valorizando, quando permitido, suas conexões com a Física Moderna. A obra também permite ao professor escolher em que nível o tratamento matemático deva ser abordado ou aprofundado. A contextualização, a 
interdisciplinaridade, o enfoque Ciência, Tecnologia e Sociedade, bem como aspectos relacionados à história da Ciência são explorados em todas as unidades da coleção. Fugindo um pouco do modelo tradicional, atividades de entrevistas, elaboração de relatórios e apresentações orais propiciam o exercício do debate e defesa de ideias e opiniões. As leis de conservação da energia mecânica e da quantidade de movimento estão organizadas em unidades distintas do primeiro volume. O conceito de torque é abordado também em outra unidade em capítulo intitulado Estática do ponto material e do corpo extenso. Embora a obra não faça referências à conservação do momento angular, o texto complementar "Giroscópio - Dinâmica do Movimento Circular" que se encontra ao final do capítulo 18 da unidade 5, sugere aos alunos que façam uma pesquisa pela internet afim de compreenderem o funcionamento e utilidade do dispositivo. É comum a ilustração de um giroscópio nos textos que tratam da CMA, sobretudo nos livros didáticos de físico do ensino superior.

\subsubsection{O lugar do conteúdo de conservação do momento angular em livros didáticos}

Passemos agora a avaliar as duas obras mencionadas no início deste capítulo cujos autores ousaram propor uma abordagem da lei da conservação do momento angular, seus conceitos e aplicações correlatos.

Figura 1.1. Capa de livro - Física: Ciência e Tecnologia

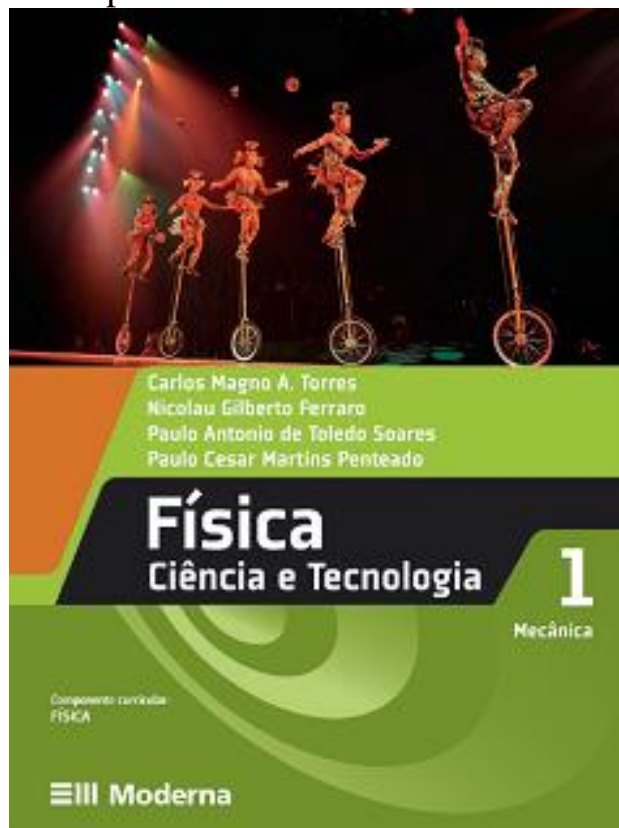

Fonte: BRASIL, 2014 
A obra Física Ciência e Tecnologia, figura 1.1, de Carlos Magno A. Torres, Nicolau Gilberto Ferraro, Paulo Antonio de Toledo Soares e Paulo Cesar Martins Penteado da editora Moderna, $3^{a}$ edição de 2013, é composta de três volumes organizados em unidades e capítulos. É dado especial destaque à abertura de cada capítulo que traz uma imagem relacionada a um texto motivador que permite e provoca a discussão sobre o tema e os conceitos a serem desenvolvidos em cada seção seguinte. A abordagem didático-pedagógica adotada pelos autores procura desenvolver nos educandos um pensamento crítico ao tratar de várias situações cotidianas que permitem explorar relações entre os conceitos físicos e as experiências vivenciais dos alunos. Nota-se uma especial preocupação em aproximar os saberes sistematizados da escola, da cultura juvenil atual, relacionando os temas da física com os jogos, computadores, esportes, séries de TV e cinema. Com efeito, contextualização e interdisciplinaridade, bem como o enfoque Ciência, Tecnologia e Sociedade, são aspectos bastante explorados, justificando a escolha do nome que dá título à coleção. Também são apontadas diferentes estratégias de ensino e avaliação compostas de entrevistas e pesquisas de temas e tecnologias atuais em comparação a outras mais antigas. As leis de conservação da energia mecânica e da quantidade de movimento são tratadas em capítulos separados e integrantes da mesma unidade II de título Força e Energia. Bem diferente de outras propostas de ensino de física para o ensino médio, a obra em questão não dispõe de um capítulo que analisa especificamente problemas que envolvam o equilíbrio do corpo extenso. O uso do conceito de torque - que dessa vez é apresentado relacionando-se com o momento angular - é aplicado diretamente e especificamente no contexto das Máquinas Simples e Alavancas, assunto do capítulo 8, também integrado à unidade II.

A proposta didática para abordagem da conservação do momento angular está localizada no último tópico do capítulo 5, Quantidade de movimento e impulso, que integra a Unidade II, no primeiro volume da coleção.

O capítulo inicia-se com o exemplo clássico de uma patinadora que girando com os seus braços abertos, tem a sua velocidade angular modificada quando os aproxima do corpo. O parágrafo não é explícito a esse ponto - não afirma que a velocidade da patinadora se modifica quando a patinadora fecha os braços - os autores desafiam o leitor a questionar sobre a possibilidade de haver alguma grandeza física que, a exemplo dos movimentos de translação já estudados, permaneça constante nos movimentos de 
rotação. Embora a suposição de existência de tal grandeza careça da informação de que a velocidade angular se modifica, a ação reflexiva na procura dessa resposta, instigoume em saber por que a CMA é tratada no tópico final do capítulo.

As duas seções imediatamente anteriores à última têm os títulos Centro de Gravidade e Equilíbrio de Corpos Apoiados, respectivamente. Ambas as seções exploram os conteúdos exclusivamente do ponto de vista qualitativo. É conhecida - e cobrada em exames vestibulares - a equação que permite calcular as coordenadas ortogonais de um sistema físico composto por figuras geométricas planas e cuja distribuição de massa superficial em cada polígono seja considerada homogênea. Nesta obra, os autores preferem não abordar tal formalismo matemático. É possível inferir, ainda que de forma especulativa, uma hipótese a fim de justificar porque o conteúdo momento angular está contido num capítulo cujo título é Quantidade de Movimento e Impulso. Não deveria ser objeto de estudo deste capítulo exclusivamente o momento linear? Ora, para entender o que é momento de inércia é preciso levar em consideração como a massa de um corpo ou um sistema físico se distribui em torno de um eixo de rotação. Tal distribuição de massa é da mesma forma relevante para se determinar a posição do centro de massa de um objeto ${ }^{2}$. Sabemos que o centro de gravidade representa o ponto de aplicação da força gravitacional sobre um corpo ou sistema físico. O traçado da reta suporte da força gravitacional relativamente à área da superfície que lhe serve de base de apoio determina se o objeto permanecerá ou não em equilíbrio sobre essa base e que tipo de equilíbrio será esse: estável, instável ou indiferente. Notase dessa forma que tais conceitos relacionam a forma e a distribuição de massa de um corpo. A compreensão por parte dos alunos de que é justamente a redistribuição da massa da patinadora em torno de seu eixo de rotação, é o que permitirá o entendimento da mudança da velocidade angular da mesma enquanto ela gira e, por conseguinte, a conservação do momento angular.

Utilizando outros dois exemplos, um atleta realizando um salto mortal e uma pessoa sentada numa cadeira giratória segurando um par de halteres, os autores justificam a introdução da equação que permite definir o momento angular $(\vec{L})$ de um corpo ou sistema físico, grandeza que permanece constante durante a rotação.

$$
\vec{L}=J \cdot \vec{\omega}
$$

\footnotetext{
${ }^{2}$ Os autores tomam o cuidado de diferenciar centro de massa de centro de gravidade, mas optam por considera-los coincidentes no estudo.
} 
Torres et. al. (2013) distinguem velocidade de rotação $(\vec{\omega})$ - grandeza vetorial e velocidade angular $(\omega)$ - grandeza escalar. Tal distinção é pouco vista em outros textos didáticos. Em capítulo anterior, já fora definido velocidade angular como a rapidez no deslocamento angular de um móvel. O momento de inércia $J$ é a grandeza física que leva em conta a distribuição de massa de um corpo em relação a um eixo de rotação. Seguindo a mesma perspectiva qualitativa, não são fornecidos detalhes em relação à definição formal do momento de inércia. O caráter vetorial tanto do momento angular quanto da velocidade de rotação será útil (e necessária) mais adiante nas seções finais do capítulo de títulos "Atividade em grupo", "Aplicação tecnológica" e "Você sabe por quê?".

Bem diferente de outras obras do ensino médio, é na seção seguinte que é apresentado o conceito de torque ou momento de uma força em relação a um eixo de rotação como a grandeza responsável pela variação do momento angular de um corpo ou sistema físico em relação a esse eixo de rotação. É bem sabido que tal grandeza aparece definida nos livros de ensino médio como o produto do módulo da força pela distância entre a reta suporte de aplicação dessa força a um eixo em torno do qual um objeto pode girar. Diversos autores de livros do ensino médio denominam essa grandeza física como momento escalar de uma força. Vê-se dessa forma, que na coleção em análise, em especial localizado no capítulo sobre Momento Angular, os autores procuram estabelecer a relação que existe entre o torque produzido por uma força e a causa direta deste torque na mudança do momento angular. Nos capítulos que tratam exclusivamente de equilíbrio de corpos rígidos ou extensos, tal relação mostra-se desnecessária já que todos os corpos em questão estarão com velocidade angular nula (ou momento angular nulo). Entretanto, os autores preocuparam-se em também destacar o caráter vetorial do torque de uma força definindo pela equação

$$
T=F \cdot d
$$

apenas o módulo do torque da força. Repare que desse ponto de vista o torque não é visto como uma grandeza escalar. Tal abordagem é importante e necessária para se que possa entender a relação entre o torque e a mudança do momento angular ou, reciprocamente, a inexistência de um torque externo e a não alteração do momento angular de um sistema físico. É neste ponto que os autores enunciam o princípio de 
conservação que serve de mote à minha investigação. "Se o torque externo resultante que age num corpo em rotação for nulo, então o momento angular permanece constante" (TORRES et. al., 2013, p. 211).

Infelizmente, os exemplos que ilustram tal conservação têm suas explicações muito sucintas e o caráter vetorial não é explorado com detalhes. Tanto o exemplo da pessoa que segura uma roda de bicicleta girando sentado em uma cadeira, quanto à explicação do movimento de precessão do pião, não são de fácil assimilação sem que haja intervenção do professor. Nesse ponto, questiono a possibilidade remota de aprendizagem autodidata por parte do aluno. Nesse mesmo sentido, as atividades propostas nas últimas três seções do capítulo mostrar-se-ão exigindo habilidades além daquelas adquiridas e desenvolvidas pela exclusiva leitura do texto. Talvez, a intenção dos autores seja de promover atividades de pesquisa em grupo com essas atividades e fomentar o trabalho autônomo dos educandos. É razoável afirmar que o êxito na compreensão das atividades propostas e a relação dos exemplos com o caráter vetorial do torque e momento angular - particularmente a variação do momento angular - serão alcançados caso os alunos já tenham uma boa desenvoltura em operações com vetores.

Por fim, o capítulo apresenta oito exercícios que avaliam de forma básica a compreensão dos conceitos apresentados no capítulo. Todos os exemplos explicados e os oito exercícios propostos apresentam e avaliam uma abordagem exclusivamente qualitativa do torque e do momento angular, apenas com destaque negativo para o enunciado do exercício proposto 26 , no qual pede-se desprezar atritos e torques externos. Entendo a intenção dos autores na elaboração da questão. Entretanto, sem atrito não há como o recipiente girar junto com a plataforma. Não obstante, as equações que definem formalmente o momento angular e o torque foram utilizadas para estabelecer relações de direta e inversa proporção numa abordagem exclusivamente qualitativa dos conceitos explorados, além de explicar e justificar os fenômenos físicos associados a eles. Tal perspectiva está em total acordo com a proposta didáticopedagógica da coleção que valoriza a estruturação, desenvolvimento e construção conceitual dos objetos de estudo da Física. 
Figura 1.2. Capa de livro - QUANTA FÍSICA.

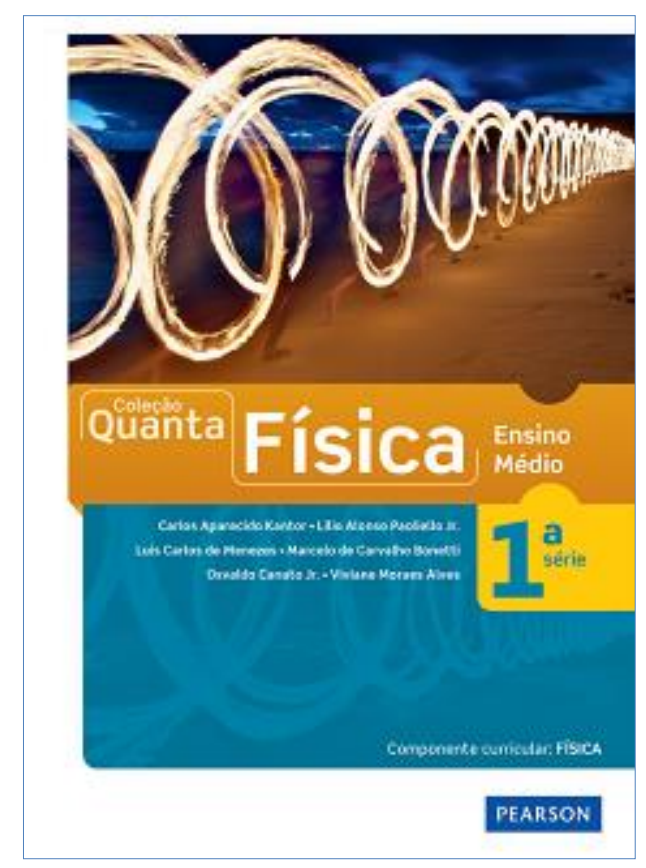

Fonte: BRASIL, 2014

A coleção Quanta Física, figura 1.2, de Carlos Aparecido Kantor, Lilio Alonso Paoliello Júnior, Luís Carlos de Menezes, Marcelo de Carvalho Bonetti, Osvaldo Canato Júnior e Viviane Moraes Alves da editora Pearson, $2^{\text {a }}$ edição de 2013, é composta por três volumes subdivididos em duas unidades temáticas cada um. Os conteúdos são selecionados e organizados de forma bem diferente de outros livros. Assuntos que costumeiramente são abordados numa determinada série do ensino médio foram organizados em volumes distintos que ainda contemplam vários outros temas relacionados à ciência e tecnologia, fugindo bastante das propostas didáticopedagógicas tradicionais que costumam supervalorizar os conteúdos restritos à Física Clássica. Em comparação a esta última, é dada igual importância à Física Moderna e Contemporânea. Os conteúdos relacionados a estas últimas também não são todos abordados num único volume, aparecendo de forma bem diversificada em toda a obra e fomentando a retomada de tais conteúdos e conceitos a eles relacionados ao longo das unidades nos três volumes da coleção. Tais conceitos são abordados via proposta temática contextualizada e interdisciplinar exemplificada a partir de situações cotidianas e aplicações tecnológicas diversas. O aprofundamento no formalismo matemático é colocado em seção à parte, dando ao professor, opção à ênfase do uso de tal abordagem. A obra também possui um conjunto de vinte e quatro objetos educacionais digitais 
(OEDs) que podem ser acessados a partir do sumário no caso do livro digital. Cada um deles é acompanhado de um texto com orientações para utilização, relevância e objetivos. Novamente se distanciando às abordagens mais tradicionais, o conceito de energia e a sua conservação são apresentados antes das leis de Newton, logo na primeira unidade do volume 1. A lei de conservação da energia mecânica é debatida no terceiro capítulo dessa unidade, seguida de capítulo que antecipa as relações termodinâmicas entre calor, trabalho e energia interna de um sistema físico como assunto pertinente à primeira série do ensino médio. É sabido que a tradição dos livros didáticos de Física traz este conteúdo apenas no ano seguinte. Não suficiente, inclua-se ainda um quinto capítulo que discute de forma bem variada muitos conceitos relacionados à eletricidade e ao magnetismo, foco do estudo da física da última série do ensino médio. Na unidade 2, em particular, no segundo capítulo intitulado As Regras do Jogo, são discutidos os conceitos de quantidade de movimento, quantidade de movimento angular e as suas conservações. Como fizera Torres et.al. (2013), comentando há pouco, aqui o conceito de torque é estudado em contexto distinto àquele relacionado ao equilíbrio de um corpo extenso. Conquanto explore questões onde a soma vetorial dos torques envolvidos é nula, a coleção de Kantor et. al. (2013) por sua vez não dispõe de significativa quantidade de exercícios propostos sobre Estática.

Utilizando abordagem equivalente àquela adotada na conservação da quantidade de movimento (momento linear) com relação aos movimentos de translação, os autores iniciam a discussão sobre as rotações no tópico Rotações Também Têm Regras, localizado no capítulo 2, da segunda unidade, primeiro livro da coleção. Por hipótese, é possível apontar a influência do material elaborado pelo Grupo de Reelaboração do Ensino da Física (GREF) nos autores da coleção em análise. Projeto bem conhecido entre os docentes, o GREF, formado por um grupo de professores da rede estadual de ensino em São Paulo e coordenados por docentes do Instituto de Física da USP, elaborou em 1984 - e revista em 2007 - uma proposta para o ensino da Física do ensino médio, diretamente vinculada à experiência cotidiana dos estudantes, e que procura apresentar a Física como um instrumento de compreensão e atuação da realidade. Tal material também tem influência significativa sobre minha proposta pedagógica, principalmente com relação às atividades experimentais. Nesse sentido, a ideia da necessidade de existência de movimentos compensatórios no caso das rotações é inevitável, mas também é simples e convincente para se introduzir uma lei mecânica de conservação da quantidade de movimento angular equivalente à lei de conservação do 
movimento linear já descrita e estudada em tópicos anteriores do mesmo capítulo. Cabe observar que os autores não utilizam a palavra momento (linear ou angular), preferindo sempre utilizar os termos quantidade de movimento linear e quantidade de movimento angular para se referir ao produto da inércia pela rapidez e direção de um movimento. Considero incomum a opção dos autores, dada a familiaridade do termo momentum tanto no âmbito do ensino médio e superior, quanto nos exames vestibulares. Sem perda de generalidade, a partir deste ponto, preferi utilizar a mesma nomenclatura presente na obra.

Em seção à parte intitulada Veja Mais: Arcos, Ângulos e Velocidades de Rotação, os autores descrevem as grandezas cinemáticas angulares posição e velocidade angular (ou velocidade de rotação), além dos conceitos de frequência e período e a aplicação de tais grandezas em sistemas físicos de transmissão de movimentos por polias e engrenagens. Aspecto positivo desta seção, haja vista que a mesma está escrita de tal forma que permite ser trabalhada independentemente dos demais assuntos discutidos no capítulo. Há inclusive, ao final, uma série de exercícios propostos que visam à aprendizagem especificamente dos conteúdos dessa seção. Infelizmente, em que pese a possibilidade de escolha do professor abordar ou não tais conceitos, o conteúdo da seção é incipiente e resumido exageradamente, além de apresentar trechos contendo equívocos matemáticos. Senão, vejamos:

O comprimento de uma circunferência de raio 1, é o número irracional 3,14159 , designado pela letra grega $\pi$ (lê-se pi). Da mesma forma, qualquer circunferência inteira dividida por seu raio resulta no mesmo valor $\pi$. (KANTOR et. al., 2013, p. 192).

O comprimento de uma circunferência de raio 1 é igual a $2 \pi$, sendo que $\pi$, é um número irracional, portanto não pode ser igual a 3,14159. Também não faz sentido ou é redundante falar de uma "circunferência inteira".

Nos dois tópicos a seguir - Quantidade de Movimento Angular e Inércia Rotacional e A Conservação da Quantidade de Movimento Angular - a argumentação segue paralela em consonância à proposta teórico-metodológica abordada na exposição da lei de conservação da quantidade de movimento linear. Exemplos que aparentam exceções ao princípio de conservação são levantados pelos autores e instigam os estudantes a elaborar respostas antecipadamente, além de incentivar a curiosidade. Pontuo também especial destaque para a seção Conexão que discute sobre o efeito da fração numérica que antecede o produto $m \cdot r^{2}$ no valor da inércia rotacional de objetos 
simétricos cuja massa encontra-se distribuída ao longo de uma direção radial ao eixo de rotação. De posse dessa análise, as justificativas físicas e matemáticas se complementam, adicionando mais credibilidade à formulação matemática de que o momento de inércia depende de como a massa do objeto está distribuída em torno do eixo de rotação. Na mesma direção, os autores salientam que objetos que tem distribuição homogênea de massa simétrica ao eixo de rotação acabam tendo, portanto, a mesma inércia rotacional.

Em Kantor et.al. (2013,p.194-197), todas as equações dos tópicos analisados no capítulo são escritas em módulo:

$$
\begin{aligned}
L & =I \cdot \omega \\
T & =F \cdot r \\
\Delta L & =I \cdot \Delta \omega \\
T & =\frac{\Delta L}{\Delta t}
\end{aligned}
$$

Onde:

$L:$ [módulo] do momento angular

$I$ : momento de inércia

$\omega:$ [módulo] da velocidade angular

$T:$ [módulo] do torque

$F:$ [módulo] da força

$r$ : distância perpendicular entre a força e o eixo de rotação

$\Delta L$ : variação [do módulo] do momento angular

$\Delta \omega$ : variação da rapidez angular

Embora eu tenha escrito com rigor a descrição de cada grandeza física presente nas equações acima, todas elas aparecem no texto sem estarem precedidas da palavra módulo. Com exceção das grandezas físicas força, velocidade e quantidade de movimento, todo o assunto é conduzido ao longo do capítulo sem evidenciar o caráter vetorial das grandezas torque, velocidade angular e quantidade de movimento angular. Não apresento aqui uma crítica, mas, diversamente a isso, o assunto é tratado com probidade e retidão, sem a necessidade nem dependência da descrição vetorial "exigida" no estudo da conservação do momento angular. Em verdade, acredito que qualquer assunto da física possa ser tratado com maior ou menor complexidade e com o mesmo rigor. A ênfase em determinados aspectos em detrimentos de outros depende obviamente de qual projeto pedagógico se almeja. A opção dos autores em não 
apresentar, ou nem ao menos de relativizar o caráter vetorial das grandezas físicas associadas aos movimentos de rotação, a meu ver, não foram intencionalmente mascaradas para enganar ou esconder a verdadeira física dos alunos do ensino médio, mas no intuito de garantir um mínimo de acesso a um conhecimento cultural, quase totalmente excluído do currículo do ensino médio sob a argumentação, creio eu, de que o estudo do momento angular e suas aplicações exigem conhecimentos matemáticos muito avançados. Qualquer assunto da física pode utilizar e/ou exigir conceitos matemáticos avançados dependendo da abordagem escolhida. Coerente à opção de abordagem dos autores, tanto os exemplos de aplicações quanto os exercícios propostos podem ser entendidos e resolvidos com o desenvolvimento "escalar" das grandezas rotacionais.

Ao explorar a comparação entre a quantidade de movimento linear e angular, o texto finaliza a apresentação do assunto buscando uma relação entre rotação e translação. A figura 1.3, retirada do original, resume a intenção dos autores.

Figura 1.3. Tabela de correspondências entre rotação e translação.

\begin{tabular}{|c|c|}
\hline \multicolumn{2}{|c|}{ Rotações } \\
\hline Grandezas angulares & Unidades (SI) \\
\hline Inércia rotacional (I) & $\mathrm{kg} \cdot \mathrm{m}^{2}$ \\
\hline Velocidade angular $(\omega)$ & $\mathrm{rad} / \mathrm{s}$ \\
\hline $\begin{array}{l}\text { Quantidade do movimento } \\
\text { angular }(\mathrm{L}=\mid \omega)\end{array}$ & $\mathrm{kg} \cdot \mathrm{m}^{2} \cdot \mathrm{rad} / \mathrm{s}$ \\
\hline Torque $(\mathrm{T})$ & $N \cdot m$ \\
\hline Aceleração angular $(\alpha)$ & $\mathrm{rad} / \mathrm{s}^{2}$ \\
\hline \multicolumn{2}{|c|}{$\begin{array}{l}\text { Lei da conservação da quantidade de } \\
\text { movimento angular. Se } T=0 \Rightarrow \Delta L=0\end{array}$} \\
\hline \multicolumn{2}{|c|}{$\begin{array}{l}\text { Lei da variaçăo da quantidade de movimento } \\
\text { angular: } \\
\Delta \mathrm{L}=\mathrm{I} \Delta \omega=\mathrm{T} \Delta \mathrm{t} \Rightarrow \mathrm{T}=\mid \alpha\end{array}$} \\
\hline \multicolumn{2}{|c|}{ Translações } \\
\hline Grandezas lineares & Unidades (SI) \\
\hline Massa (m) & $\mathrm{kg}$ \\
\hline Velocidade linear (v) & $\mathrm{m} / \mathrm{s}$ \\
\hline $\begin{array}{l}\text { Quantidade de movimento } \\
\text { linear }(p=m \cdot v)\end{array}$ & $\mathrm{kg} \cdot \mathrm{m} / \mathrm{s}$ \\
\hline Força (F) & $\mathrm{N}$ \\
\hline Aceleração linear (a) & $\mathrm{m} / \mathrm{s}^{2}$ \\
\hline \multicolumn{2}{|c|}{$\begin{array}{l}\text { Lei da conservação da quantidade de } \\
\text { movimento linear. Se } F=0 \Rightarrow \Delta p=0\end{array}$} \\
\hline \multicolumn{2}{|c|}{$\begin{array}{l}\text { Lei da variação da quantidade de movimento } \\
\text { angular: } \\
\Delta \mathrm{p}=\mathrm{m} \Delta \mathrm{v}=\mathrm{F} \Delta \mathrm{t} \Rightarrow \mathrm{F}=\mathrm{m} \cdot \mathrm{a}\end{array}$} \\
\hline
\end{tabular}

Fonte: KANTOR et. al., 2013, p.192. 
Com o objetivo de finalizar essa análise dos livros didáticos do PNLD, mais especificamente dos dois últimos, uma vez em que foram eles a abordarem acentuadamente o conteúdo da conservação do momento angular, promovo aqui minhas últimas considerações nesta revisão. Embora não faça parte de meu escopo proceder a uma comparação, o estudo aprofundado e o interesse por este conteúdo causam-me inevitável ímpeto de fazer este exercício final.

Posto isto, em minha opinião, o trabalho de Kantor et. al. (2013) demonstra maior coerência frente aos objetivos declarados em sua proposta pedagógica. A opção de Torres et. al. (2013) pelo quase abandono do ferramental matemático em função de uma suposta perda de contextualização à aplicabilidade dos fenômenos físicos, fizeram com que o livro fragilize aspectos relacionados à avaliação da aprendizagem em torno do conteúdo abordado. O arrefecimento do nível dos exercícios deste conteúdo em Torres et. al. (2013) em relação ao nível dos exercícios dos demais assuntos do livro pode demonstrar certa desvalorização do conteúdo da conservação do momento angular, dada a escassez de aprofundamento operacional - exercícios propostos pelos autores do tema. Isso particularmente não acontece em Kantor et. al. (2013), que embora não forneça o rigor e aprofundamento nas questões e exercícios propostos que são tão propalados em obras "vestibularescas", não deixa ao menos de manter coerência no que diz respeito a colocar o conteúdo da conservação do momento angular lado a lado com os demais temas abordados no livro. 


\section{Capítulo 2 \\ 0 professor-pesquisador em física e a (real) necessidade de fundamentos teórico-pedagógicos em sua formação}

Até aqui foram apresentados os aspectos fundadores da problemática de minha pesquisa, os fundamentos teóricos expressos no recorte bibliográfico dos estudos em torno do ensino da conservação do momento angular (CMA) e as formas de abordagem desse conteúdo em livros didáticos regulados por uma política nacional com este fim, o PNLD. A próxima etapa é delinear o estudo em torno de um referencial teórico de cunho pedagógico. Trata-se, assim, de um momento no qual necessito identificar numa teoria educacional, ou melhor, em uma teoria de aprendizagem um ponto de apoio heurístico que fundamentou minhas ideias expressadas pelo produto educacional elaborado, implementado e avaliado. Por isso, vale recuperar as orientações de Marco Antônio Moreira, importante figura acadêmica na criação do mestrado profissional em ensino de física e atualmente coordenador de pós-graduação do MNPEF. Para ele esta seção que, obrigatoriamente se inscreve nas dissertações, não se trata da "adoção" de uma teoria e muito menos proceder a um capítulo "só para constar". Procurei intitular este capítulo e, de forma provocativa, registro entre parênteses a palavra "real", que no contexto do título, serve como adjetivo à necessidade de tais fundamentos teóricos pedagógicos estarem presentes na formação do professor que produz pesquisa em ensino de física. Discutir isso nesse momento, mais do que "apenas" identificar uma teoria que engendrou meu produto, vai ao encontro das recomendações de Moreira, porque o sentido de estudar teorias pedagógicas está em observar que nosso objeto não é a física isolada da escola. Ao contrário, é a física que só tem sentido em meio ao contexto da escola, instituição que historicamente guarda o papel social de lugar de apropriação do conhecimento sistematizado e acumulado pela humanidade. Dito isto, destaco que tomei como objetivo neste capítulo, além de situar o leitor frente ao referencial teórico que deu base a proposta pedagógica em CMA, o de expressar o que desafia os professores de física a serem antes de físicos, professores.

O marco teórico que edificou o produto educacional que apresento nesta dissertação está, em boa parte, nos pressupostos teóricos da aprendizagem significativa de David Ausubel estudado em Moreira (2009, 2011). Creio ter tido empatia pelas ideias de Ausubel logo nos primeiros contatos com a sua teoria. Recordo-me de uma 
passagem em especial que pode perfeitamente ser lida como uma espécie de aforismo de sua teoria:

Se tivesse que reduzir toda a psicologia educacional a um só princípio, diria o seguinte: o fator isolado mais importante que influencia a aprendizagem é aquilo que o aprendiz já sabe. Averigue isso e ensineo de acordo. (AUSUBEL apud MOREIRA, 2009).

Moreira (2009) compreende esta passagem como uma síntese do pensamento de Ausubel. Particularmente, aprecio a totalidade deste trecho em especial. Ausubel não escreveu que aquilo que o aprendiz já sabe determina aquilo que ele é capaz de aprender. Ou seja, embora importante, aquilo já internalizado não é uma condição sine qua non da aprendizagem. Contudo, ela influencia diretamente a aprendizagem. Minha compreensão, quando dos primeiros contatos com estas ideias, é de que o aluno se motiva quando se torna ciente de que o professor compreende o que ele sabe e toma tal informação como objeto de estratégia de ensino para fazê-lo avançar em torno de um determinado conhecimento.

Segundo Moreira (2011, p.26, grifos do autor) para Ausubel, a "aprendizagem significativa é o processo através do qual uma nova informação (um novo conhecimento) se relaciona de maneira não arbitrária e substantiva (não-literal) à estrutura cognitiva do aprendiz". Aqui duas categorias fundamentais emergem do pensamento de Ausubel e que orientam as ações de ensino que tomam a aprendizagem significativa como esteio pedagógico. O "não arbitrário" trata-se de uma qualidade que um determinado conhecimento deve exercer sobre a estrutura cognitiva do aprendiz. No caso, um conhecimento pode ser potencialmente significativo na medida em que este se relaciona de forma não arbitrária àquilo que o aprendiz já conhece. A estrutura cognitiva que Ausubel menciona não se constitui em qualquer conhecimento, mas sim àqueles que se relacionam de forma relevante ao que se pretende aprender. Esses conhecimentos prévios, presentes na estrutura cognitiva do aprendiz, Ausubel chamou de subsunçores. Em minha proposta, tais subsunçores estão presentes de forma explícita.

"Substantividade significa que o que é incorporado à estrutura cognitiva é a substância do novo conhecimento, das novas ideias, não as palavras precisas usadas para expressá-las" (MOREIRA, 2011, p.26). Aqui Ausubel defende que um determinado conhecimento expressado em conceitos não se fecha às infinitas variantes de sua representação. Por isso, o atendimento a uma aprendizagem significativa não deve se dispor a exclusivas formas ou meios de ensino. O signo, fator representacional dos conhecimentos, não deve ser alheio ao aprendiz. Ao contrário, os signos 
representativos dos conhecimentos devem ter simbolicamente significados na estrutura cognitiva do aprendiz.

Logo, está no entrelaçamento entre algo que chega ao aprendiz de forma não arbitrária e que é substancialmente atraente, porque embora novo, não o é de todo estranho, a razão para a emergência da aprendizagem significativa.

Além de Ausubel e sua aprendizagem significativa, outro importante teórico pode atravessar, de forma bastante contundente, algumas particularidades da minha proposta didática para o ensino da CMA. Trata-se do matemático Yves Chevallard e sua teoria da Transposição Didática ${ }^{3}$. A preocupação de Chevallard está baseada em como se dá o processo que decorre entre a produção do conhecimento científico até as práticas sociais escolares que almejam absorver e apreender tal conhecimento. Ou seja, o objetivo é procurar compreender como o saber produzido pelos cientistas é transformado para atender as idiossincrasias da escola, tornando-se um objeto de ensino (BROCKINGTON; PIETROCOLA, 2005).

Chevallard havia percebido que existem "esferas do saber", de maneira que é possível pensar em três categorias importantes para compreender aquilo que ele chamou de transposição didática. A primeira categoria é "o saber sábio", que seria o conhecimento produzido e se apresenta na comunidade científica. Independentemente das tensões que as teorias científicas encerram em torno de disputas científicas, elas possuem legitimidade enquanto ciência, sendo isso importante no que diz respeito à presença destes conhecimentos na escola. A segunda categoria é "o saber a ensinar", que é a transposição do conhecimento científico para uma nova lógica que esteja adequada ao contexto escolar e que observe os vários intervenientes do sistema educacional em geral. O "saber a ensinar" surge nos livros e materiais didáticos, nos programas e nos currículos que organizam o ensino. A terceira categoria é a do "saber ensinado", que seria o conhecimento que o professor produz quando ensina determinado conhecimento. A questão nesta terceira categoria tem a ver com a ideia de que o conhecimento, mesmo sendo ofertado em livros e programas, não se constitui de forma totalmente coincidente. Ofereceria esta categoria uma segunda transposição didática, o “saber ensinar” em "saber ensinado" (BROCKINGTON; PIETROCOLA, 2005).

\footnotetext{
${ }^{3}$ A inserção de Chevallard e a teoria da transposição didática nesta seção correspondem ao atendimento às sugestões críticas da banca avaliadora da dissertação, que seguiu profícua discussão durante o momento de defesa deste trabalho.
} 
Em Chevallard observei um importante elemento na relação ensinoaprendizagem. Acostumado a pensar tal relação de forma restrita ao professor e ao aluno, percebi que a teoria da transposição didática faz recrudescer o "saber" como um elemento que deve compor uma tríade de aprendizagem na escola (professor-alunosaber) e que abre uma possibilidade epistemológica (para as pesquisas em "ensino de") no que tange novas relações, sobretudo a de professor-saber e aluno-saber. Certamente, algo bastante apropriado em minha diligência neste estudo e que fortalece minha defesa em torno do conhecimento, em meu caso, da CMA. A propósito disso, encontrei em Chevallard os seguintes questionamentos:

[...] o que é então aquilo que, no sistema didático, se coloca sob o estandarte de O Saber? O "saber ensinado" que concretamente encontra o observador, que relação estabelece com o que se proclama dele fora desse âmbito? E que relação estabelece então com o "saber sábio" [...]? Quais distâncias existem entre um e outro? (CHEVALLARD apud BROCKINGTON; PIETROCOLA, 2005, p.392).

Tais questionamentos de Chevallard provocam reflexões que traduzem o hiato entre o "saber sábio" e o "saber ensinado". De fato, tal reflexão conduziu-me a ratificar a necessidade de pensar o ensino de física observando esse processo. Assim, este teórico auxilia em uma justificação teórica para a minha empreitada, reforçando o desejo de elaborar uma proposta de ensino, que nos termos de Chevallard, se encaminharia como um esforço produtivo científico de realizar uma transposição didática observando o conhecimento da CMA. Vale dizer que tal contribuição, embora fundamental para o meu crescimento formativo como professor, não se fez de maneira direta na elaboração da proposta didática e, por conseguinte, não é referenciada na discussão dos resultados da pesquisa.

Não obstante os pressupostos teóricos de Ausubel e Chevallard serem representativos de minha proposta é preciso dizer que eles não foram os determinantes dela. Registrar isso aqui me ajuda a avançar rumo ao meu segundo objetivo nesta seção e que tem a ver com o desafio de viver a docência em física na educação básica, razão maior desta pesquisa. Uma coisa é verificar em quais pontos um determinado produto educacional - estratégia formativa neste mestrado profissional - se relaciona a uma teoria educacional, e outra coisa é produzir um produto a partir de uma determinada teoria educacional. Nesse sentido, talvez fosse necessário discutir se a compreensão de teoria na física é a mesma compreensão na educação. Por hipótese, arrisco dizer que não. Pensando do ponto de vista epistemológico, acabo asseverando ainda mais minhas 
convicções sobre isso. As ciências duras, palco da hegemonia científica da física, certamente em nada se coadunam às pesquisas educacionais. Estas, do ponto de vista epistêmico, têm suas bases fundadas nas ciências humanas e sociais. São inegáveis, em minha opinião, os avanços para uma interdisciplinaridade que a linha de pesquisa de ensino de ciência vem promovendo na pós-graduação. Mesmo assim, o caráter pragmático da pesquisa e a necessidade - quase obrigatoriedade - de se investigar a aplicação de produtos pedagógicos são pontos discutíveis em termos epistemológicos na educação. Se em física é muito claro que teoria se aplica, talvez em educação não. Talvez, em educação, teoria explique determinado fenômeno. E ao conseguir explicar, o professor pesquisador pode assim retroalimentar sua própria formação, sem dicotomias, uma vez em que a teoria está assim integrada ao contexto de prática. Pesquisar seria uma forma de tornar o professor autônomo. O valor pedagógico das produções que elaborei - produto educacional e objeto dessa pesquisa - talvez seja maior para mim do que para os alunos. Se isso se confirmar verdadeiro, melhor para os meus futuros alunos. 


\section{Capítulo 3 \\ Considerações teórico-metodológicas e os intervenientes da pesquisa}

\subsection{Introdução}

A pesquisa se caracteriza como um estudo de abordagem qualitativa. A pesquisa qualitativa, segundo Gil (2002), não pode ser traduzida em números, de forma que a análise de fenômenos da realidade pretendida na investigação necessariamente passa por um processo de interpretação do pesquisador, o qual produz conhecimento com base nos dados coletados e produzidos.

Assim, a presente investigação se organizou a partir de duas etapas relativamente distintas. Na primeira etapa busquei apropriar-me de elementos teóricos da investigação em ensino de física, especificamente aqueles que tinham como fito o ensino da conservação do momento angular na educação básica. Tratava-se de estudos de literatura referenciada academicamente. Cabe ressaltar que as disciplinas presentes na matriz curricular do curso de mestrado profissional (MNPEF) compreenderam este momento da pesquisa, ora contribuindo diretamente na construção de exercícios de pesquisa e estudo, ora indiretamente por meio de debates entre professores e estudantes ao longo curso. Destaque à disciplina "Fundamentos Metodológicos para Pesquisa e Ensino de Física" ministrada pelas professoras Eliana dos Reis Nunes e Maria de Fátima da Silva Verdeaux, a qual possibilitou a elaboração de uma estrutura científica do trabalho. Além disso, alimentou ideias metodológicas com ênfase no escopo formativo da pós-graduação profissional e ao anseio de geração de produtos científicos contextualizados ao ensino de ciências para o ensino básico. Integrou ainda a primeira etapa do trabalho a organização e posterior análise de material didático de ensino de física na educação básica, especificamente aqueles utilizados no Ensino Médio da escola brasileira, quais sejam os livros didáticos de física circunscritos ao Plano Nacional do Livro Didático (PNLD). A análise objetivou inicialmente perceber a ocorrência do conteúdo da Conservação do Momento Angular (CMA). Foram analisados 14 livros didáticos e constatado que em apenas dois se observava a presença minimamente fundamentada do conteúdo de CMA. Esse processo de análise de livros didáticos a partir do PNLD, somado aos estudos de pesquisas em ensino da CMA, resultaram na produção dos capítulos iniciais da dissertação e identificados no corpo do texto como revisão de literatura. 
A segunda etapa da pesquisa tinha como escopo a elaboração de uma proposta didático-pedagógica acerca do conteúdo da CMA para o ensino médio. Tal produto educacional foi produzido para se caracterizar como um suporte pedagógico ao professor que decide tematizar este conteúdo em suas aulas na escola, observando a quase ausência dele em livros didáticos. Ter o professor como foco e o sujeito a quem se destina o produto educacional por mim produzido, gerou algumas determinações importantes no percurso da investigação e, sobretudo, em algumas opções metodológicas da pesquisa.

Reza a "tradição" das pesquisas oriundas do mestrado profissional, a dimensão de aplicabilidade e vivência pedagógica de produtos educacionais em contexto real de ensino especificamente com os alunos. A defesa de pesquisa aplicada em face ao escopo da formação no MNPEF orienta para o desenvolvimento, a implementação e avaliação de um produto educacional ${ }^{4}$ com vistas à melhoria e a atualização do ensino de física na escola. Os aspectos ora levantados por esta orientação foram contemplados em meu trabalho, embora os sujeitos a quem se destinassem meus objetivos científicos, jamais foram os alunos. Nesse sentido, sempre entendi que os alunos estariam sendo considerados em função de meus objetivos pedagógicos implícitos na proposta produzida. Convém incluir este debate uma vez em que parece uma tendência das pesquisas dessa natureza (pesquisa aplicada) a ideia de que o produto educacional possui “eficácia em si mesmo". Que sozinho - bastando ser aplicado - é capaz de gerar ou produzir aprendizagem. Centralizar o ensino no aluno - algo que procurei fazer através das ações de minha proposta fundamentada pela aprendizagem significativa de Ausubel e aqui já esclarecido - não quer dizer que se deve desconsiderar a importância da mediação pedagógica (o professor) para o êxito de qualquer proposta ou produto educacional. Com efeito, observando estas (provisórias) convicções não caberia colocar minha proposta ao crivo dos alunos, sem antes, e isso me parece óbvio, proceder a uma investigação de base qualitativa frente à percepção de professores de física em face ao produto elaborado.

Tais argumentações não se tratam de justificativa, mas sim de opção metodológica em função do meu escopo como pesquisador e as condições objetivas as quais estão submetidas qualquer pesquisa. Mesmo um pesquisador iniciante - como é o meu caso - deve ter claro que o cronograma de pesquisa não determina as ações da

\footnotetext{
${ }^{4}$ Entende-se como "produto educacional"; os softwares, os textos didáticos, vídeos, equipamento e outros materiais que tenham como objetivo dar suporte e auxiliar no ensino.
} 
investigação que se move para a apreensão do objeto, mas senão ao contrário. As contingências do processo de investigação é que determinam o cronograma. As atribuições laborais, as atividades disciplinares do curso de formação em pós-graduação e as demandas de estudos são condicionantes temporais que interferem diretamente no percurso metodológico de uma pesquisa. Nesse sentido, entendo pertinente a aplicação da proposta procurando objetivar respostas das experiências de ensino com os alunos. Entretanto, em respeito à excelência exigida pelo MNPEF, em meu caso, isso resultaria na superficialidade dos resultados do estudo. Portanto, a opção por dar voz aos professores e focalizar neles a minha experiência investigativa não se deu apenas por tornar exequível a pesquisa. A escolha por esse caminho se deve a acreditar que eles, cônscios de sua realidade, podem contribuir contundentemente à qualificação da proposta. Assim, no tempo devido, ela há de ser utilizada em sala de aula ou equivalente, mas como um produto enriquecido das experiências destes professores e dos conhecimentos explorados em meio aos estudos por meio da pós-graduação.

Logo, explorar o olhar de professores de física que trabalham no contexto da educação básica, conduziu minha pesquisa a se apropriar de alguns recursos técnicos metodológicos. Estes aspectos técnicos bem como a descrição dos sujeitos da pesquisa são destacados adiante em seção própria. A seguir também são destacados como foram organizados os dados da pesquisa e sua posterior análise que se configuraram no capítulo de resultados e discussão. Por fim, outras duas seções finalizam este capítulo de metodologia. Preferi trazer os comentários da proposta (produto educacional) e a forma com que ela foi desenvolvida em uma destas seções, para na sequência, discorrer sobre como tal produto foi apresentado aos professores que participaram da pesquisa. Entendo que desta maneira, o leitor terá um panorama completo daquilo que virá no próximo capítulo da dissertação.

\subsection{Sujeitos da pesquisa}

Os sujeitos da pesquisa foram selecionados a partir de um grupo de professores de física que atualmente lecionam na educação básica. Sujeitos com os quais eu já tinha contato em função da proximidade profissional e outros indicados por estes e de mesmo perfil.

A proposta foi apresentada para nove professores. Quatro deles se dispuseram a participar da pesquisa nos termos que estabeleci, quais sejam, os de realizar a leitura do 
material e se dispor a comentá-lo por escrito e/ou participar de uma entrevista. Abaixo, descrevo um perfil geral sobre os participantes, mantendo em sigilo sua identidade.

Sujeito A: professor de física da escola pública da Secretaria de Estado de Educação do Distrito Federal (SEEDF) no segmento Educação de Jovens e Adultos (EJA). Experiência em cursos preparatórios para vestibulares. Graduado em Licenciatura em 2007. Pós-graduação em Docência no Ensino Superior Lato Sensu em 2010. Há 14 anos trabalha no magistério.

Sujeito B: professor de física da escola pública da SEEDF e professor de física de escola privada em Brasília. Graduado em Licenciatura em 2006. Trabalha na área educacional há 10 anos.

Sujeito C: professor de física do ensino superior e do ensino médio do Instituto Federal de Goiás (IFG). Graduado em Licenciatura no ano de 2010. Mestrado em Ensino de Ciências em 2014. Leciona há 10 anos.

Sujeito D: professor de física da escola pública da SEEDF e professor de escola particular em Brasília. Graduado em Licenciatura no ano de 1998. Há 20 anos trabalha no magistério.

\subsection{Recursos técnico-metodológicos}

Duas técnicas de pesquisa foram requeridas para a obtenção dos dados: a bibliográfica e a entrevista semiestruturada. Segundo Gil (2002) as técnicas de pesquisa são os meios pelos quais o pesquisador produz os dados da pesquisa. A pesquisa com ênfase na técnica bibliográfica procura subsidiar os dados a partir das fontes de livros, revistas científicas especializadas entre outros meios de publicação escrita. A entrevista semiestruturada, por sua vez, se constitui como roteiro de grandes questões abertas que deve auxiliar o pesquisador na obtenção de informações do fenômeno que se busca por meio do diálogo. A entrevista semiestruturada não deve ser estanque, ao contrário, deve ser fluida e animar os sujeitos da pesquisa a se tornarem verdadeiros colaboradores (MINAYO, 1994).

Estes dois recursos metodológicos foram aqueles que induziram a coleta e produção de dados frente aos objetivos do estudo. A primeira etapa já constituída na 
revisão de literatura e retomada ao longo da discussão e, a segunda etapa, refletindo sobre as falas e comentários dos professores que analisaram a proposta.

\subsection{Esclarecimentos sobre a análise de dados}

O conteúdo das entrevistas foi gravado, depois degravado e transcrito para posterior análise. As entrevistas tiveram duração de 37 minutos para o sujeito A, 26 minutos para o sujeito $\mathrm{B}, 43$ minutos para o sujeito $\mathrm{C}$ e 32 minutos para sujeito $\mathrm{D}$. Outras observações foram também enviadas por escrito via email a posteriori a fim de responder indagações que me acometeram quando da etapa da transcrição textual das falas dos sujeitos.

$\mathrm{O}$ roteiro de entrevistas se baseou em alguns eixos temáticos de assuntos possíveis de serem abordados pelos sujeitos entrevistados. Foram quatro os apontamentos que abriram e se tornaram mote das entrevistas com os sujeitos, quais sejam: a) sobre o potencial pedagógico do produto educacional analisado e avaliado; b) sobre o rigor técnico matemático e conceitual e as possibilidades de inovação pedagógica a partir da proposta; c) sobre a natureza da proposta ter características de roteiro fechado e com pouco espaço de intervenção do professor; d) sobre as motivações do professor com relação ao seu uso em face às possíveis dificuldades em aplicá-lo em sala de aula ou equivalente.

Organizei as ideias dos professores-sujeitos segundo os eixos temáticos supracitados de modo que fosse possível comparar as respostas dos sujeitos entre si e entre cada um e a proposta original. Quando era pertinente, realizei cotejamento com a literatura referenciada na dissertação, mais especificamente aspectos abordados nos livros didáticos analisados, na literatura acadêmica revisada e eventualmente por meio de outras referências. Ademais, sempre que possível procurei desdobrar novas ideias e sugestões. No capítulo de resultados e discussões, passei a denominar os professoressujeitos desta pesquisa apenas como "sujeitos" para que não houvesse confusão entre a identificação ora do professor entrevistado, ora do professor que se imagina utilizando a proposta didática com seus alunos.

\subsection{Proposta pedagógica em conservação do momento angular: desenvolvimento e comentários}

$\mathrm{O}$ texto que segue nesta seção recupera e esclarece o processo de desenvolvimento da proposta pedagógica em conservação do momento angular (CMA). 
O objetivo aqui foi de justificar algumas opções de forma e conteúdo que são desenvolvidos no interior da proposta.

Destaco que o texto didático e as orientações dispostas na confecção da proposta foram elaborados com auxílio dos seguintes materiais: a) livro 1 de Mecânica do Grupo Reelaboração do Ensino de Física (GREF); b) o livro "Física 1" de Alberto Gaspar; c) o livro "Quanta Física" e "Física: Ciência e Tecnologia", ambos amplamente abordados na revisão de literatura; d) vídeo da série "Universo Mecânico", mais especificamente aquele intitulado "Momento Angular", e) o livro "Fundamentos da Física 1" de David Halliday e Robert Resnick.

O bom entendimento do texto didático tanto por parte do professor como sua utilização frente aos alunos pressupõe conhecimento das leis de Newton, resultante centrípeta, energia e trabalho, equilíbrio do ponto material e do corpo rígido, gravitação universal, entre outros. Vejo dessa forma uma excelente oportunidade de integrar os conteúdos da $1^{\text {a }}$ série do ensino médio, trabalhados ao longo do ano. Além disso, é possível revisá-los, caso haja intenção de aproveitar o ensejo direcionando os alunos para os exames vestibulares. Já estou inferindo, portanto, que o assunto aqui desenvolvido só poderá ser inserido no currículo da $1^{\mathrm{a}}$ série do ensino médio ao final do terceiro período ou início do quarto período do ano letivo, a depender do cronograma da escola e do planejamento de aulas do professor, podendo anteceder os conteúdos de hidrostática e hidrodinâmica. Este último, raramente contido nos livros didáticos de física do ensino básico.

Um dos aspectos a ser destacado - talvez o mais fundamental de todos - diz respeito aos pré-requisitos matemáticos. Recuperando as ideias de David Ausubel, o conhecimento prévio do aluno é a chave para a aprendizagem significativa. Para o psicólogo, aprender significativamente é ampliar e reconfigurar as ideias previamente existentes para com elas ser capaz de relacionar e acessar novos conteúdos. Nesse sentido, novas informações precisam ser ancoradas em conhecimentos anteriores com os quais precisam estar relacionadas. Aqui, em particular, a proposta didática será suprimida de sua essência metodológica caso os alunos não possuam de antemão os prérequisitos matemáticos mínimos para entendimento do vocabulário e compreensão do raciocínio a ser desenvolvido pelo professor durante a exposição. Há de se ter cuidado, a

\footnotetext{
${ }^{5}$ Série de vídeos produzidos em 1985 por California Institute of Technology (Caltech), publicado pela Corporation for Community College Television e Annenberg/CPB Project, sob o título de "The Mechanical Universe".
} 
fim de assegurar que os alunos dominam e possuem desenvoltura com tais assuntos precedentes.

Toda a proposta foi desenvolvida sem adentrar rigorosamente no tratamento vetorial das grandezas angulares. Os conceitos e ferramentas matemáticas adequadas ao estudo dos movimentos de rotação são abstratos e pouco intuitivos. De fato, a atribuição de um vetor para representar uma torção não tem nada de intuitivo. Mesmo um aluno de graduação em física demonstra estranheza ao tomar conhecimento de que as grandezas relacionadas aos movimentos de rotação são vetoriais. De forma instintiva, espera-se que algo se movimente ou aponte na direção de um vetor. No caso das grandezas angulares, algo gira em torno da direção desses vetores. A regra da mão direita, utilizada para definir a direção do torque por meio da posição estendida do polegar, por exemplo, acaba sendo mais útil no movimento que os demais dedos fazem ao curvaremse acompanhando a rotação do vetor posição $\vec{r}$ em relação ao vetor força $\vec{F}$. Com efeito, é esse "sentido rotacional" aquele explorado nos capítulos de estática do corpo rígido pelos livros didáticos de física no intuito de diferenciar um torque positivo de um torque negativo. Pessoalmente, somente a partir do conhecimento da relação vetorial entre o torque resultante e a variação do momento angular $-2^{\mathrm{a}}$ lei de Newton para as rotações é que pude perceber a importância, adequação e necessidade de uma descrição vetorial das grandezas angulares. A justificativa de que a representação da velocidade angular por meio de um vetor perpendicular ao plano de rotação (dada pela regra da mão direita) elimina as ambiguidades quanto aos referenciais é interessante, mas a definição de um sentido de rotação que não aponta no sentido em que ocorre tal rotação continua sendo contra intuitivo. Por essas razões, optei pela elaboração de um material que "foge" da apresentação rigorosa das grandezas angulares, mas privilegia uma apresentação simples, acessível e adequada às necessidades e possibilidades ao nível do ensino médio nas escolas brasileiras.

O leitor ao acompanhar o texto didático perceberá que, embora eu não adentre rigorosamente na matemática com vetores, há bastante rigor e valorização do ferramental matemático básico utilizado que é acessível aos alunos secundaristas. Imagino ser possível tratar o assunto apenas do ponto de vista conceitual e qualitativo, porém, por minha própria formação educativa, não abro mão de forma alguma das oportunidades de se desenvolver e praticar o uso da matemática. Considero a matemática, junto com a disciplina de língua portuguesa - língua nativa, em nosso caso - os componentes curriculares de maior relevância sem os quais nenhum outro poderia 
ser desenvolvido. A física só é física por causa da matemática. Durante minhas aulas, costumo "traduzir" o título da obra mais importante de Isaac Newton, Princípios Matemáticos da Filosofia Natural, como expressão sinonímica de Física. A física sem a parte matemática, a meu ver, seria a antiga filosofia natural, assim chamada e desenvolvida por muitos pensadores durante amplo período histórico. Não se engane o leitor que acaso pretendo depreciar a Filosofia, que entendo como componente curricular de igual relevância a todos os demais, com exceção da matemática e da língua portuguesa como já frisei. Tenho consciência da existência de possibilidades para abordagem do conteúdo da conservação do momento angular sem o tratamento matemático devido. Tive contato com tais propostas no desenrolar desta pesquisa como já descrito e narrado nos capítulos anteriores. Eu mesmo faço um recorte para um viés matemático que segrega o tratamento vetorial das grandezas angulares. Parece óbvio dizer nesse momento: se fosse para fazer algo igual ou parecido com o que já existe, não haveria motivações que, a meu ver, justificassem meu empreendimento.

Quanto ao vocabulário empregado, em especial às denominações físicas dadas ao produto da inércia pela rapidez nos movimentos dos corpos e sistemas físicos, optei por transitar de forma bem diversificada por todas elas: momento linear, quantidade de movimento, quantidade de movimento de translação, momento angular, quantidade de movimento de rotação. Segundo o dicionário eletrônico Dictionary.com o termo Momento é originário do latim momentum e significa 'força física de um objeto ou velocidade para se movimentar'. A palavra foi empregada por Sir Isaac Newton para descrever um corpo em movimento. Hoje, o conceito a ela associado é chamado momento ou momento linear e é representado pela letra $\mathrm{p}$ é calculada pela equação matemática $p=m \cdot v$, onde $m$ é a massa e $v$, a velocidade do objeto cuja massa é $m$.

A ideia de utilizar o mesmo conceito com denominações diversas, a meu ver, contribui tanto no reconhecimento da grandeza física a qual se está se referindo como na construção e apreensão de um novo 'momento', agora relacionado ao movimento angular. $\mathrm{O}$ conceito remete à ideia de um ímpeto que um determinado corpo possui por estar em movimento. Tal ímpeto pode ser interpretado como tendência de permanência natural deste estado - é disso que trata a $1^{\text {a }}$ lei de Newton - ou à potência que um determinado corpo possui de modo a ser capaz de provocar alguma modificação em sua interação com outro corpo ou outro meio físico. Corroborando Ausubel novamente, novos conceitos serão apreendidos com maior significado na medida em que se assemelham ou se relacionam com conceitos e conhecimentos anteriores. 
Cabe ressalva quanto à opção da nomenclatura 'torque' para a grandeza física que mede a torção exercida por uma força ou a tendência dela em provocar a aceleração angular de um corpo em relação a um eixo de rotação. A denominação mais comum encontrada nos livros didáticos é Momento de uma Força. Não acuso nenhum problema ou desgosto particular por essa terminologia, haja vista que ela está em total acordo à capacidade ou potência de uma força em provocar um movimento de giro. Minha opção pelo vocábulo 'torque' ao invés de 'momento de uma força' aparece no sentido de delimitar um significado restrito e específico a cada grandeza física, mitigando possíveis confusões provenientes de baralhadas de conceitos homônimos, porém de acepções físicas diferentes.

Em relação às unidades das grandezas físicas, sobretudo do momento de inércia e momento angular, não cabe nenhum grande refinamento teórico. As grandezas supracitadas não têm unidades próprias: o módulo do momento de inércia é dado pelo produto $\mathrm{kg} \cdot \mathrm{m}^{2}$, e o módulo do momento angular, pelo produto $\mathrm{kg} \cdot \mathrm{m}^{2} \cdot \mathrm{s}^{-1}$, ou $\mathrm{J} \cdot \mathrm{s}$. Diferentemente de outras grandezas físicas, não recebem denominações em especial. Trata-se de grandezas físicas auxiliares, cujos valores são úteis na obtenção de outras de maior interesse ou de maior relevância; além de possuírem interpretações de difícil compreensão. No texto didático, há um único exercício envolvendo cálculo matemático - que pode naturalmente ser resolvido mentalmente - que pudesse exigir uma transcrição algébrica da conservação do momento angular para o papel. Ademais, é sabido que muitos professores de física têm o (mau) costume de não representar as unidades das grandezas físicas nas equações algébricas, preferindo evidenciá-las só após a obtenção do resultado matemático final.

Apesar de serem muito comuns nos livros didáticos que abordam a conservação do momento angular, optei por não apresentar os contumazes exemplos com 'helicópteros' por entender que a explicação generalizada para esses casos só poderia ser obtida levando-se em consideração o caráter vetorial do momento angular. Não seria difícil explorar similaridades entre o caso de um helicóptero com as hélices funcionando parado junto ao chão com os eletrodomésticos, que funcionam sem sofrerem movimento de rotação por causa do atrito com a superfície onde estão apoiados. Estes últimos foram os exemplos escolhidos para ilustrar a $3^{\text {a }}$ lei de Newton para a rotação presentes em minha proposta pedagógica. Mas como não comentar agora acerca da estabilidade desse meio de transporte em situação de voo? Dizer apenas que é graças ao torque gerado pelas hélices traseiras do veículo que ele se mantém em equilíbrio, não é 
suficiente. Explico: seria preciso falar a respeito do caráter vetorial do torque e do momento angular a ser contrabalançado, ou seja, não seria possível adentrar em explicações sobre as justificativas físicas quanto à estabilidade do helicóptero quando ele está voando sem o uso do ferramental vetorial aqui preterido. Conquanto se perca a oportunidade de falar de cenas de filmes de ação nas quais helicópteros giram descontroladamente por perderem a cauda, optei por seguir um roteiro não tão abrangente, nem tão rigoroso, mas que me permitisse abraçar uma quantidade significativa de exemplos nos limites da abordagem "escalar" escolhida, como foi justificado no início dessa seção. Nesse sentido, a proposta pedagógica a ser apresentada adiante, guarda similaridades a abordagem expressada por Kantor et. al. (2013). Consoante a essa escolha, não cabe discutir, de forma singular, o funcionamento dos modelos de helicópteros de dois rotores principais. Infelizmente, há de se pagar de alguma forma pela perda de generalidade ou a invenção de uma "generalidade específica”.

Por fim, concluo o texto didático dispondo uma série de instruções e dicas de como fazer uma bola de basquete girar na ponta dos dedos. Ali não há objetivos de natureza pedagógica, salvo provocar o leitor de forma descontraída, a possibilidade de "se arriscar" em tal habilidade motora. Questões de vestibulares, com seus respectivos gabaritos, foram adicionados ao final oportunizando ao professor ilustrar como o assunto já foi cobrado em exames para o ingresso em instituições de ensino superior, além da possibilidade de averiguar com os alunos, se houve alguma apropriação dos conteúdos debatidos ao longo da proposta pedagógica.

Demais considerações acerca de especificidades do material e sugestões de atividades são feitas ao longo do texto didático, que foi confeccionado de modo a manter um constante diálogo com o professor. Tais considerações são parte constituidora da proposta.

$\mathrm{Na}$ sequência, passo a apresentação da proposta didática. Trata-se da cópia fiel do produto educacional que está disponível de forma independente desta dissertação e tem como alvo o professor do ensino básico. Trata-se de texto orientador narrado em prosa que aborda o conteúdo da conservação do momento angular acessível aos alunos do ensino médio, e que dispõe de instrumental matemático compatível àquele pertinente ao currículo de matemática da educação básica. 


\subsection{Proposta pedagógica em conservação do momento angular: texto didático}

\section{Conservação do momento angular - uma proposta de ensino}

O texto a seguir tem como propósito a apresentação de uma proposta de abordagem do conteúdo da conservação do momento angular direcionada para o professor e acessível aos alunos do ensino médio, dispondo de instrumental matemático compatível àquele pertinente ao currículo de matemática da educação básica. O material aqui descrito pressupõe conhecimento das leis de Newton, resultante centrípeta, energia e trabalho, equilíbrio do ponto material e do corpo rígido, gravitação universal.

Por que é possível equilibrar uma bola de basquete sobre o dedo quando ela está girando? (Figura 3.1)

Figura 3.1. Harlem Globetrotter ajuda garota a equilibrar a bola de basquete.

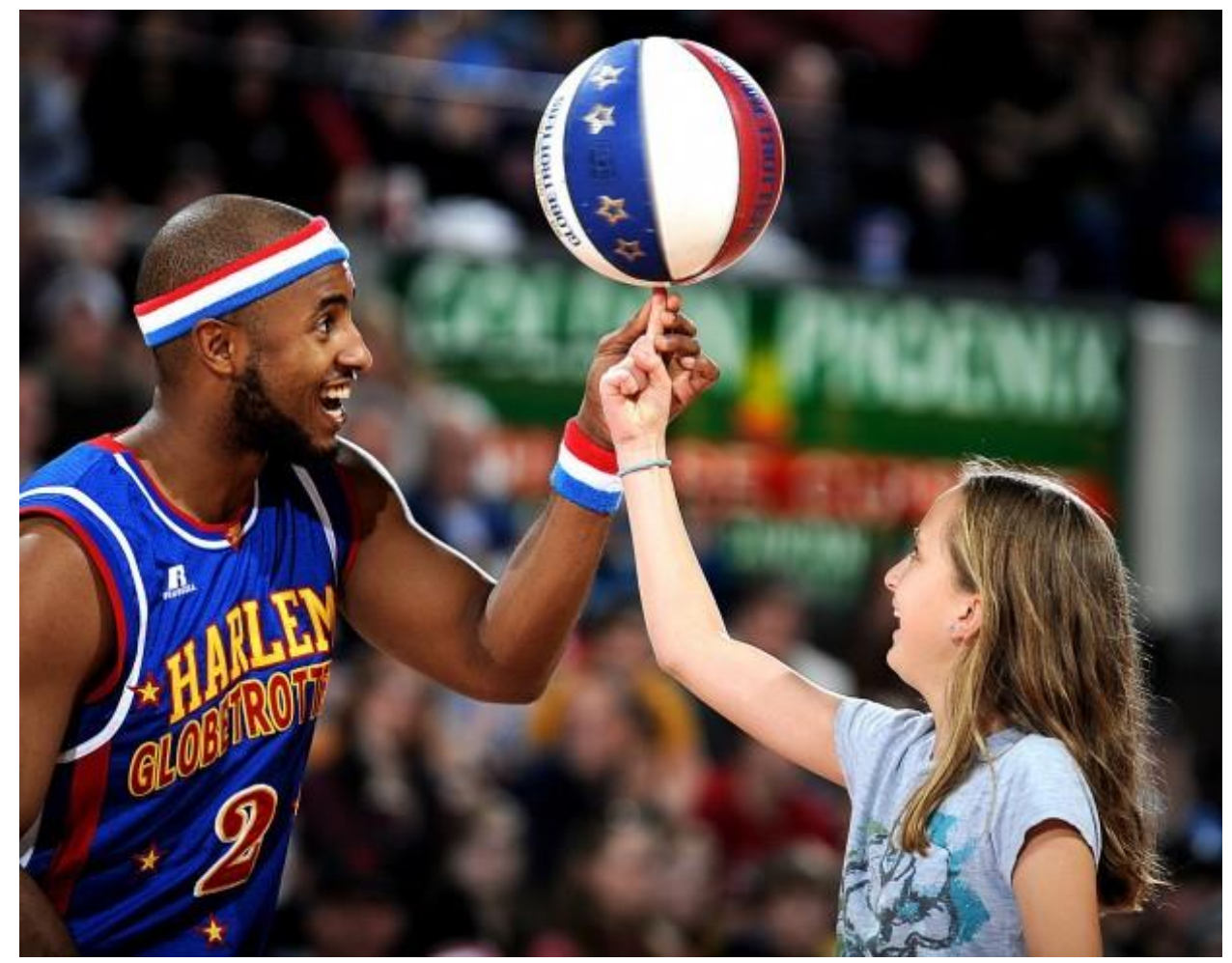

Foto de LARRY MAYER/Gazette Staff. Fonte:

<http://billingsgazette.com/news/local/globetrotters-dazzle-arena-audience-with-their-deftbasketball-skills/article_49cf2193-654c-534e-8b9e-929cbdb72539.html>. Acesso em: $1^{\circ} \mathrm{de}$ outubro de 2015. 


\section{A MOTIVAÇÃO INICIAL}

Caso seja possível - e o professor tenha treinado o suficiente - leve uma bola de basquete para a sala de aula e equilibre-a no dedo enquanto ela gira ${ }^{6}$. Deixe-a perder velocidade para que os alunos percebam como isso afeta o equilíbrio. Faça a bola ganhar velocidade novamente girando-a com a outra mão para que eles percebam que o equilíbrio está relacionado diretamente com a velocidade de rotação da bola. Mesmo que o professor não seja capaz de girar a bola, leve-a! É possível que algum dos seus alunos consiga! Se não tiver a bola de basquete, use um caderno de capa dura. É mais fácil! Pergunte aos alunos por quê?

Aproveite para dar outros exemplos de fenômenos que tem a ver com essa demonstração: um pião girando sobre uma mesa, um prato que pode ser equilibrado por uma vareta, um pneu fino de bicicleta que permanece "em pé" enquanto estiver rolando sobre uma superfície. Até mesmo os Segways (diciclos elétricos) da polícia, figura 3.2, têm a ver com o que estamos falando!

Figura 3.2. Segways da polícia militar de Pernambuco.

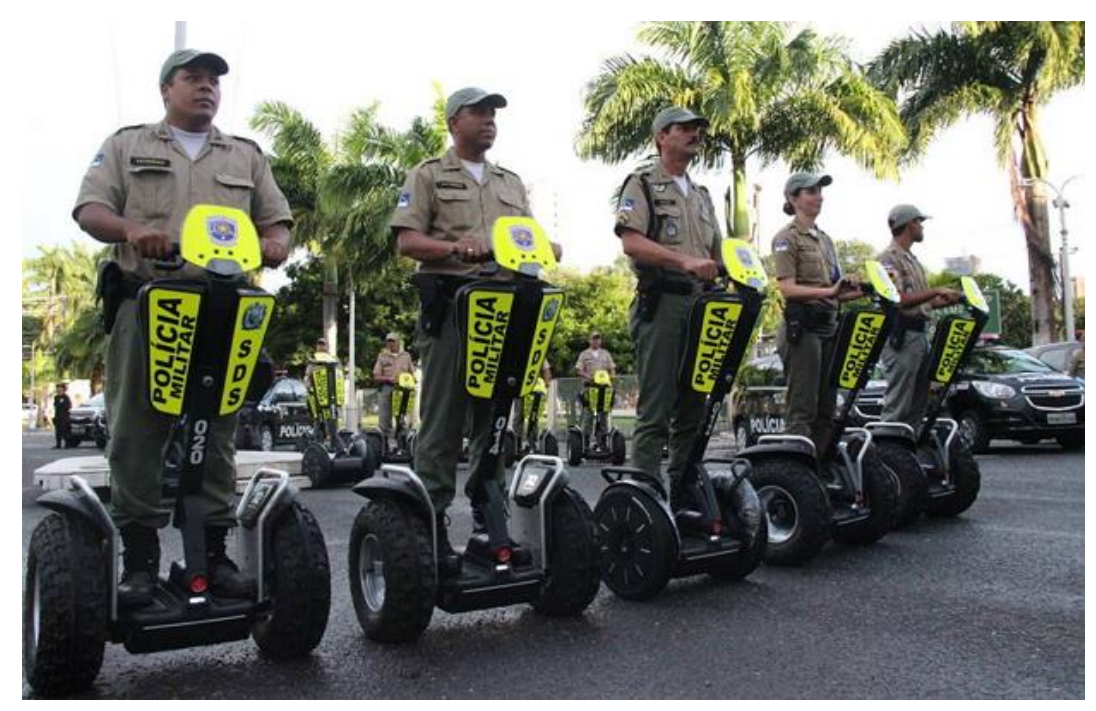

Fonte: <http://www.folhadoararipe.com.br/os-segways-sao-os-novos-equipamentos-da-policiamilitar-de-pernambuco/>. Acesso em: $1^{\circ}$ de outubro de 2015.

\footnotetext{
${ }^{6}$ Se não tiver a bola de basquete e/ou ninguém conseguir equilibrá-la, mostre o vídeo "Professor de física faz truque incrível e é 'convocado' pelo Globetrotters" no YouTube acessível através do link: <https://www.youtube.com/watch?v=RxQuot3pZQ4>. Acesso em: 11 de janeiro de 2016.
} 


\section{A EXPERIÊNCIA INICIAL}

A proposta de experiência didática a seguir pode ser igualmente útil nas aulas dedicadas ao conceito de resultante centrípeta. Iremos explorar a relação entre a resultante centrípeta, velocidade, raio da trajetória circular e massa na equação fundamental da dinâmica ( $2^{\mathrm{a}}$ lei de Newton) aplicada ao movimento circular. Caso ache necessário, recapitule os conceitos e as grandezas contidas na equação abaixo.

$$
F_{c p}=m a_{c p}=m \frac{v^{2}}{r}
$$

Sobretudo, as modificações propostas e os resultados observados na terceira abordagem da experiência descrita abaixo serão de especial interesse para o nosso trabalho, pois estarão relacionados à conservação do momento angular como veremos adiante.

Vamos utilizar o tubo de uma caneta esferográfica do tipo BIC, cerca de um metro e meio de um barbante e uma daquelas borrachas com capinhas de plástico (figura 3.3).

Figura 3.3. Materiais.
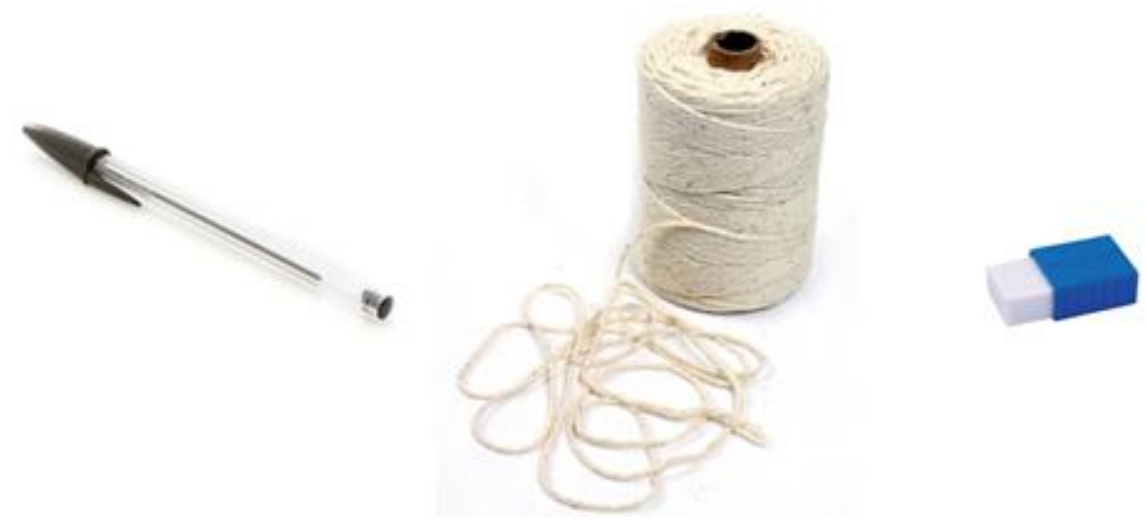

Retire a carga da caneta e passe o barbante que foi amarrado à capinha de plástico da borracha, por dentro do tubo como sugere o desenho abaixo. Ver montagem na figura 3.4 . 
Figura 3.4. Montagem.

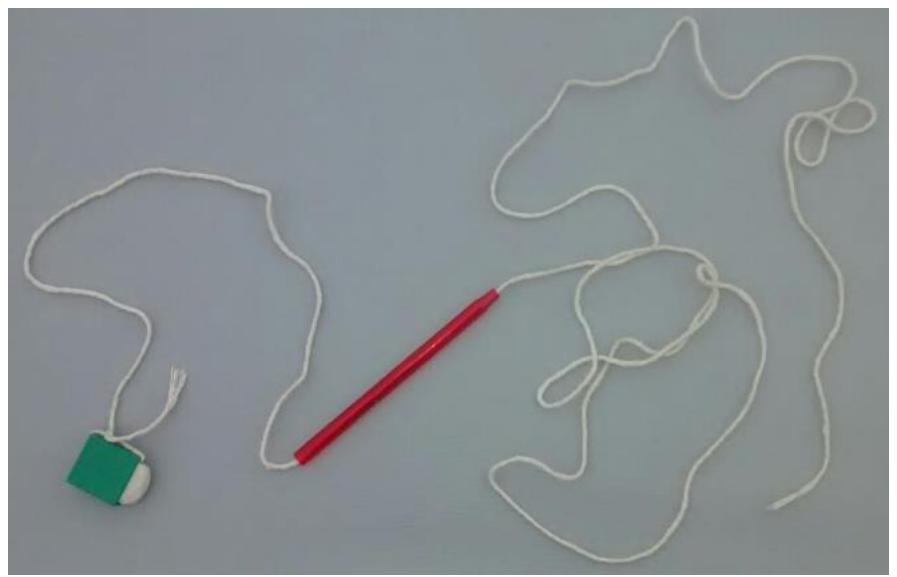

Segurando o tubo da caneta com uma das mãos e a extremidade livre do barbante com a outra, faça a borracha girar em movimento circular em um plano horizontal paralelo ao chão, como sugere a figura 3.5.

Figura 3.5. Borracha girando em movimento circular em plano paralelo ao chão.

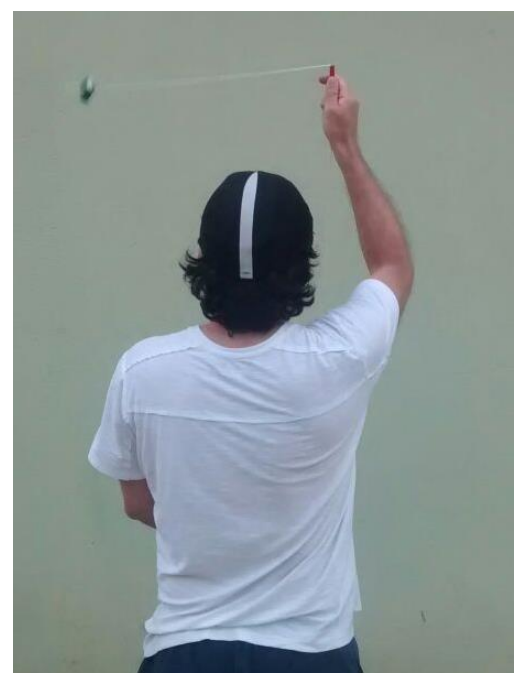

Solicite a participação de um aluno para segurar a extremidade livre do barbante, enquanto você, segurando o tubo, provoca o movimento circular na borracha. Faça a borracha girar num plano acima de sua cabeça. Cuidado! Alerte o seu aluno-ajudante que enrole ou amarre a extremidade por ele segura, a fim de que a borracha não saia "voando" pela sala fora! Se preferir, mude a disposição do aparato para que a borracha gire num plano vertical conforme sugere a figura 3.6. Tome os meus cuidados para a que o barbante nem a borracha se soltem durante a experiência! 
Figura 3.6. Borracha girando em movimento circular em plano perpendicular ao chão.

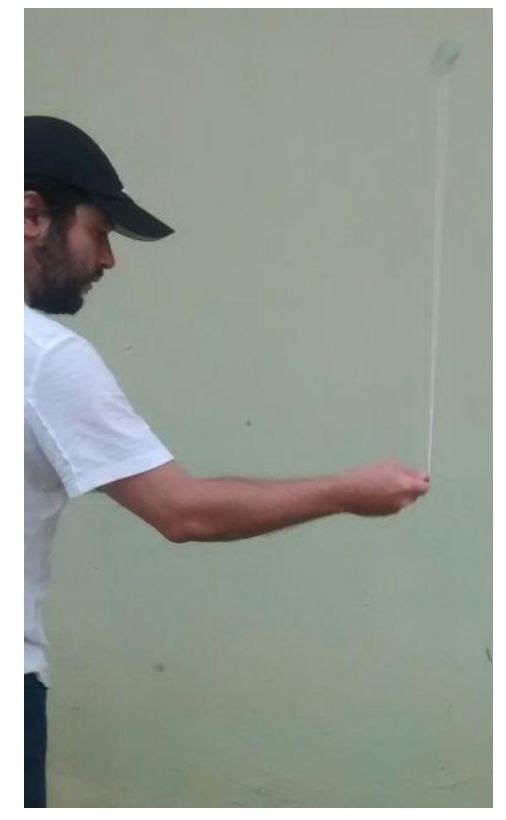

Rigorosamente, em ambas as situações, a força gravitacional está agindo externamente sobre o conjunto. Serão necessárias algumas aproximações para que o sistema seja considerado "isolado": a borracha não gira rigorosamente em plano horizontal paralelo ao chão (figura 3.5) e o módulo de sua velocidade muda constante quando gira em plano perpendicular ao solo (figura 3.6). Ao professor cabe a escolha de chamar a atenção de seus alunos para tais aproximações, a depender do nível de profundidade que deseja dar ao assunto, compatível ao grau de facilidade/dificuldade de acompanhamento da turma.

Enquanto a borracha estiver girando, pergunte ao seu aluno se ele precisa aplicar uma força muito ou pouco intensa para segurar a borracha. A intenção é que ele compartilhe suas sensações com a turma dizendo ao grupo se faz uma força maior ou menor ao segurar o barbante. Mais uma vez: assegure-se de que ele não soltará o barbante!

Faça a borracha girar com maior velocidade, tentando não modificar o comprimento do barbante que representa o raio de giro no movimento circular da borracha. Pergunte a ele sobre o esforço que faz para segurar a borracha. Num segundo momento, retire a borracha deixando o barbante enrolado apenas à capinha plástica. Repita a experiência. Novamente, tente fazer com que a peça de plástico gire num raio e velocidade parecidos com aqueles da situação anterior. Peça a ele que compare a força 
que está fazendo agora com aquela que precisava para segurar a capinha com a borracha dentro. Colocando novamente a borracha dentro da capinha, modifique o raio de giro, afastando ou aproximando o tubo das mãos do aluno enquanto o conjunto gira. $\mathrm{O}$ que ele percebe agora?

O objetivo aqui é obter respostas esperadas concernentes à teoria já desenvolvida quando do estudo das leis dinâmicas do movimento, sobretudo com relação à $2^{\mathrm{a}}$ lei de Newton aplicada ao movimento circular. Vamos analisar cada uma das situações supracitadas, verificando, com o auxílio de nosso aluno-ajudante, como varia o módulo da resultante centrípeta em cada uma delas.

$\left.1^{a}\right)$ Modificando a velocidade: girando o tubo da caneta mais rapidamente.

A força com a qual o aluno segura o barbante é transmitida, em parte, à capinha com a borracha e atua como força centrípeta, garantindo que o conjunto permaneça em trajetória circular. Como o módulo da força centrípeta está relacionado ao quadrado do módulo da velocidade do objeto que sofre a ação desta força, pela equação dinâmica, percebemos que há uma relação de direta proporção entre ambos, desde que a massa e o raio da trajetória não se modifiquem. Daí a importância do professor tentar manter inalterado o comprimento do trecho do barbante que experimenta o movimento circular.

Isolando as grandezas físicas que permanecem constantes:

$$
F_{c p}=m \frac{v^{2}}{r} \Leftrightarrow \frac{m}{r}=\frac{F_{c p}}{v^{2}}=\text { constante }
$$

O módulo da resultante centrípeta é diretamente proporcional ao quadrado do módulo da velocidade, para massa e raio constantes.

$$
F_{c p} \propto v^{2}
$$

Isso justifica matematicamente porque o aluno dirá que sente aplicar uma força mais intensa para uma maior velocidade de giro, e menos intensa para uma menor velocidade de giro.

$2^{\text {a) }}$ Modificando a massa: retirando a borracha de dentro da capinha.

Analisando a mesma equação e, sem se modificar nem a velocidade nem o raio da trajetória circular, vemos que o módulo da força centrípeta depende do valor da massa do objeto que gira.

Isolando as grandezas físicas inalteradas: 


$$
F_{c p}=m \frac{v^{2}}{r} \Leftrightarrow \frac{v^{2}}{r}=\frac{F_{c p}}{m}=\text { constante }
$$

Nesse caso, o módulo da força centrípeta e o valor da massa são diretamente proporcionais, para velocidade e raio constantes.

$$
F_{c p} \propto m
$$

Esta verificação matemática é de fácil convencimento: o objeto de massa menor precisa de menor força para segurá-lo; um objeto de massa maior precisará de maior força para mantê-lo em movimento circular.

$3^{\text {a) }}$ Modificando o raio: deslizando o tubo da caneta ao longo do barbante.

Repare que nas duas situações anteriores, procedemos de forma a modificar a velocidade e a massa do conjunto capinha-borracha, sempre procurando manter inalteradas as outras duas grandezas físicas que estavam presentes do lado direito da equação. Só o que fizemos até o momento foi verificar experimentalmente, analisando a proporcionalidade entre as grandezas físicas envolvidas, a veracidade da $2^{\text {a }}$ lei de Newton aplicada ao movimento circular.

Analisando a maneira pela qual decidimos alterar o raio da trajetória circular, percebemos que não só uma, mas duas grandezas se modificam invariavelmente: raio e velocidade. $\mathrm{O}$ efeito dessas duas variações sobre o módulo da resultante centrípeta pode ser analisado do mesmo modo que fizemos antes. Repare.

Isolando apenas a massa na equação:

$$
F_{c p}=m \frac{v^{2}}{r} \Leftrightarrow m=F_{c p} \cdot \frac{r}{v^{2}}=\text { constante }
$$

Ao se encurtar o raio de giro, concomitantemente o conjunto passa a girar a uma velocidade maior. Com numerador diminuindo e denominador aumentando na fração à direita, a razão entre o raio e o quadrado do módulo da velocidade diminui. O módulo da força centrípeta aumenta. Por outro lado, se aproximarmos o tubo das mãos do aluno, percebemos um aumento do raio de giro acompanhado de uma diminuição da velocidade do conjunto capinha-borracha. Nessa segunda situação, com aumento do numerador e decréscimo do denominador da fração, a razão entre o raio de giro e o quadrado do módulo da velocidade aumenta: a força centrípeta tem módulo menor agora. $\mathrm{O}$ aluno precisa fazer mais força para segurar a borracha no primeiro caso e sente aplicar uma força menor no segundo caso. Posto isso, conclui-se, que há uma relação 
inversa entre o módulo da força centrípeta e a razão entre o raio e quadrado do módulo da velocidade.

$$
F_{c p} \propto \frac{1}{r / v^{2}}
$$

Até este ponto a discussão acima poderia encaixar-se de forma muito adequada em uma aula cujo tema se restringisse ao conceito e aplicações da força centrípeta: considerações sobre a velocidade ao tentar fazer uma curva, diferença na força de atrito exercida sobre carros e caminhões ao fazer uma curva, cuidados quanto ao traçado em curvas mais abertas ou mais fechadas em corridas, por exemplo. Entretanto, o que pretendemos indagar aqui é por que a velocidade da borracha muda ao alterarmos o raio da sua trajetória? O que fizemos nesta terceira situação foi reposicionar o tubo da caneta de modo a modificar o comprimento do barbante que gira preso à borracha. Ao arrastar o tubo da esferográfica sobre o barbante, a única interação que aparece além daquelas já existentes será uma força de atrito entre o barbante e a borda do tubo da caneta onde aquele desliza. Certamente, tal força de atrito não acarretaria um aumento, mas uma diminuição no módulo da velocidade do conjunto. Ainda que o aluno puxasse o barbante para si - diminuindo também dessa forma o raio de giro - a força aplicada seria transmitida ao longo da direção do barbante, atuando sobre a capinha com a borracha numa direção perpendicular ao movimento em cada instante. Alguém poderia argumentar que ao puxar a corda, realiza-se um trabalho sobre a borracha, fazendo com que a sua energia cinética aumente, justificando dessa forma por qual motivo a velocidade aumenta e o raio diminui. Mas esse argumento não pode ser igualmente utilizado quando alterávamos a posição do tubo deslizando-o sobre o barbante. Há uma forma diferente - e ao mesmo tempo correta e interessante - de explicar a dupla alteração das grandezas físicas raio e velocidade!

É neste ponto que começaremos a nossa argumentação no sentido de apresentar e explicar a lei de conservação do momento angular.

\section{UMA APARENTE CONTRADIÇÃO}

A força tensora no barbante - que atua como resultante centrípeta no movimento - não pode causar nenhum torque, pois esta força é paralela ao braço do momento (distância perpendicular do eixo de rotação à reta suporte da força) aqui materializado pelo trecho do barbante que tem direção radial ao movimento circular da borracha. Mas não há torque... Então por que a velocidade se modifica? 
Os resultados obtidos de nossas observações em relação à terceira forma de abordar a experiência da borracha giratória parecem sugerir algum vínculo entre as grandezas físicas velocidade e raio: o aumento de uma está associado à redução da outra, e vice-versa. Mas repare que isso acontece ao longo de um movimento circular: a borracha gira! Faz uma curva! Ora, como há objetos experimentando movimentos giratórios nessa experiência, podemos supor que o momento de uma força - o torque tenha algo a ver com tudo isso! ${ }^{7}$ A força transmitida pelo barbante à borracha de fato poderia alterar a sua velocidade. Se a força de tração do barbante sobre a borracha produzir um torque, ele poderá ajudar na rotação da borracha, ajudando-a a girar mais depressa. Dessa forma o módulo de sua velocidade aumentaria. Mas no caso específico da experiência não há torque algum! O torque provocado pela força tensora no barbante é nulo, pois, como já foi dito anteriormente, não há distância perpendicular entre o eixo de giro e a linha de ação da força de tração que é transmitida à borracha pelo barbante. Então como a velocidade muda? Afinal, há realmente outra maneira de explicar por que a velocidade fica diferente? Curiosamente a resposta que procuramos está "escondida" justamente no fato do torque ser nulo...

\section{HÁ MUITOS OUTROS EXEMPLOS}

Pergunte aos seus alunos: será que já estudamos alguma situação em que isso também acontece? Outras situações em que o torque é nulo. É provável que alguns deles se lembrem das condições para o equilíbrio do corpo extenso. Mas a pergunta aqui se refere à outra coisa. Será que já vimos em algum outro assunto que foi estudado ao longo do ano, algo que aumentava a velocidade ao mesmo tempo em que uma distância (raio) diminuía? Instigue os seus alunos para que façam um esforço de tentarem lembrar-se de alguma outra situação onde um aumento/redução de uma distância era acompanhado de uma redução/aumento de velocidade, respectivamente. Se não for o suficiente, peça que pensem em algum movimento curvilíneo onde isso acontece! A ideia aqui é que eles se recordem da $2^{\mathrm{a}}$ lei de Kepler.

Relembre com os seus alunos, as três leis de Kepler e a lei da Gravitação Universal de Newton. Uma das maneiras mais famosas de enunciar a $2^{\text {a }}$ lei de Kepler é dizer que o vetor posição de um planeta em relação ao Sol varre áreas iguais em tempos iguais. Como as órbitas são elípticas, os planetas não se movem ao redor do Sol com a

\footnotetext{
${ }^{7}$ Caso considere conveniente e/ou necessário, o professor pode aproveitar 'este momento' para relembrar o 'conceito de momento' (de uma força) com seus alunos.
} 
mesma rapidez. Sua velocidade varia constantemente: é maior quando está mais próximo do Sol e menor quando está mais afastado, como é explicado na figura 3.7.

Figura 3.7. $2^{\mathrm{a}}$ lei de Kepler: a "lei das áreas".

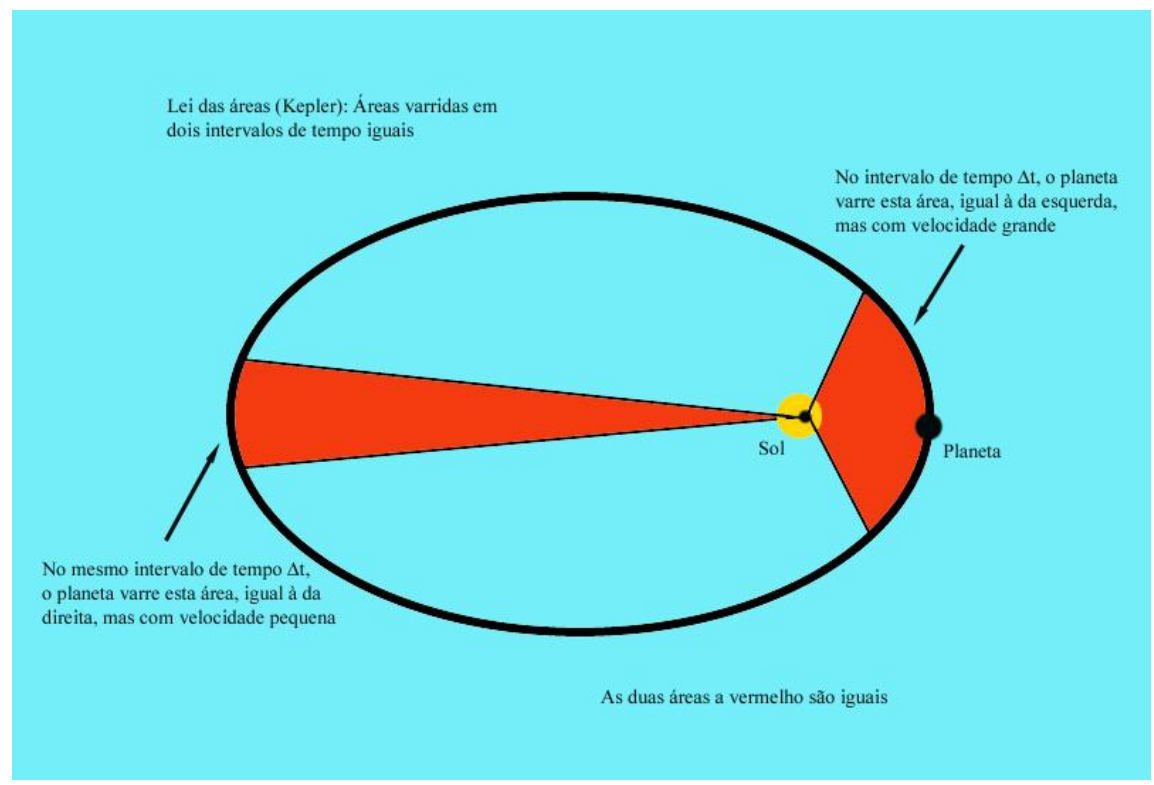

Fonte: <http://cmup.fc.up.pt/cmup/feynman/node3LeiAreas.html $>$. Acesso em $1^{\circ}$ de outubro de 2015.

Lembre seus alunos que, embora Kepler soubesse dessa verdade, ele não sabia por que isso era verdade. Coube a Newton com a ideia de força gravitacional, responder esse por quê. De forma alternativa, aproveite o momento para retomar o conceito de trabalho de uma força e, em especial de uma força conservativa, onde ocorre o intercâmbio entre energia potencial e energia cinética: quando a distância ao Sol é menor, a velocidade é maior; quando a distância é maior, a velocidade é menor. Isso explica a aparente inversa proporção entre velocidade e distância. Mas e o torque da força gravitacional? Peça ajuda aos seus alunos no sentido de identificar a direção da força em cada instante e o braço do momento representado pela distância ao Sol. São paralelos. Não há torque. Da mesma forma ao que acontece na terceira modificação da experiência com a borracha.

Aproveite para mencionar que existem muitos outros casos onde o torque resultante é nulo e, ao mesmo tempo, uma compensação entre velocidade e distância parecem estar presentes. O caso de um redemoinho na água de uma pia ou banheira, causado por um ralo que se abre é especialmente interessante. Se houver algo boiando enquanto a água é drenada pelo ralo, será fácil perceber a mudança de velocidade desse objeto flutuante enquanto ele gira sobre o dreno: quanto mais próximo do buraco 
(menor distância), maior a rapidez. Na realidade, cada gota de água obedece ao mesmo movimento em espiral ao redor do ralo. De forma geral, objetos em rotação em situações onde o torque resultante externo é nulo, obedecem a uma mesma lei básica. Outros exemplos: o caso clássico de uma bailarina ou patinadora que, adquirindo um movimento de rotação inicial, consegue sem nenhuma interação externa, aumentar ou reduzir a sua velocidade de giro. Movimentos em piruetas executados por ginastas também têm a ver com o assunto em debate. Não revele ainda como eles conseguem causar essa mudança de velocidade! Tampouco fale, nesse ponto, de momento angular! Vamos em seguida, desenvolver uma argumentação matemática análoga àquela habitualmente apresentada nos livros de ensino médio para relacionar o Teorema do Impulso/Quantidade de Movimento com a $2^{\text {a }}$ lei de Newton. O que precisamos responder é: qual é exatamente a relação matemática entre a velocidade e o raio?

\section{A EXPLICAÇÃO: RELAÇÃO ENTRE MOVIMENTO LINEAR E ANGULAR}

Pela $2^{a}$ lei de Newton, a velocidade de um corpo é alterada se existir uma força externa não equilibrada aplicada sobre ele. Reciprocamente, se não houver forças - ou se a resultante das forças aplicadas for nula - a velocidade desse corpo não é modificada. Matematicamente, em módulo,

$$
F_{R}=0 \Rightarrow m \cdot a=0 \Rightarrow m \cdot \frac{\Delta v}{\Delta t}=0
$$

Multiplicando por $\Delta t$ ambos os lados da igualdade acima temos:

$$
m \cdot \Delta v=0 \Rightarrow m \cdot\left(v-v_{0}\right)=0 \Rightarrow m \cdot v=m \cdot v_{0}=\text { constante }
$$

Ao produto da massa pela velocidade, demos o nome de Quantidade de Movimento ou Momento Linear:

$$
p=m \cdot v(\text { em módulo })
$$

Nas aulas de conservação da quantidade de movimento - aproveite para relembrar seus alunos - havíamos concluído que se a força externa é nula, o momento linear se conserva. Em outras palavras: a conservação da quantidade de movimento vem da lei de Newton. Para um corpo, essa afirmação é apenas uma forma diferente de enunciar a sua $1^{\text {a }}$ lei: por inércia, um corpo tende a manter o seu estado de movimento. Ou seja, é natural que um corpo já em movimento (em equilíbrio) permaneça em 
movimento (em equilíbrio). Chame a atenção de seus alunos - é provável que nós professores precisemos relembrar isso ainda muitas vezes - que essa lei diz respeito a dois tipos de equilíbrio: estático e dinâmico! Não há conservação do momento linear da borracha ou do planeta. Ambos variam sua velocidade, em módulo e em direção, ao percorrerem a trajetória curvilínea. Isso é razoável, já que existem forças atuando sobre eles. Mas são forças cujo torque é nulo! E daí?

Este é um momento importante da aula. Procuremos o que há de comum em situações de equilíbrio de translação e rotação. O que é necessário para cada um dos tipos de equilíbrio estar presente? Quando estudamos o Equilíbrio (Estático) de um Corpo Extenso - mais uma oportunidade para relembrar conceitos - havia duas condições para que um objeto se mantivesse em equilíbrio: força resultante nula e torque resultante nulo. Se a força resultante era nula, então o corpo não sofreria movimento de translação. Se o torque resultante era nulo, o corpo não experimentava movimento de rotação. Entretanto, se a força resultante é nula, a lei de Newton também prevê que o corpo pode estar em movimento: movimento retilíneo uniforme. Analogamente a isso, talvez, se o torque resultante for nulo, o corpo também pode estar em movimento e em equilíbrio! Um equilíbrio no movimento de rotação: um movimento circular uniforme. A intenção aqui, professor, é que mostremos aos nossos alunos que o torque é uma torção que, da mesma forma que a força, tem o papel de alterar estados de repouso e movimento. Enquanto a força é a grandeza física relacionada à alteração da velocidade de translação, o torque é a grandeza física relacionada à alteração da velocidade de rotação. A esta velocidade de rotação, já sabemos de aulas anteriores, damos o nome de velocidade angular.

Reescrevendo a definição matemática de torque de uma força resultante e usando a $2^{\mathrm{a}}$ lei de Newton.

$$
\tau_{R}=F_{R} \cdot d_{\perp}=m \cdot a \cdot d_{\perp}
$$

Para o caso de uma força resultante perpendicular ao braço do momento num movimento circular uniforme temos

$$
d_{\perp}=r
$$

A relação entre a aceleração linear $a$ e a aceleração angular $\alpha$ é dada por

$$
a=\alpha \cdot r
$$


Substituindo estas duas últimas expressões na definição matemática do torque de uma força temos:

$$
\begin{gathered}
\tau_{R}=m \cdot a \cdot d_{\perp}=m \cdot \alpha \cdot r \cdot r \\
\tau_{R}=m \cdot r^{2} \cdot \alpha
\end{gathered}
$$

Conduza seus alunos a compararem essa equação com a $2^{\mathrm{a}}$ lei de Newton. O que há de semelhante? O que há de diferente? Não responda ainda! Deixe que eles pensem a respeito. Se não conseguirem, reescreva a equação assim:

Equação dinâmica do torque: $\tau_{R}=\left(m \cdot r^{2}\right) \cdot \alpha$

Equação dinâmica da força: $F_{R}=m \cdot a$

Quem sabe agora alguém consiga... O que se espera nesse momento é que algum de seus alunos consiga ver uma estrutura matemática parecida com a famosa $2^{\mathrm{a}}$ lei de Newton com a qual eles trabalharam o ano inteiro! O termo entre parênteses equivale à massa presente na $2^{\mathrm{a}}$ lei de Newton e ainda carrega consigo um fator quadrático de distância, o que poderia sugerir alguma relação com áreas - uma superfície circular, talvez... Mesmo sendo especulações, este exercício inquisitivo é de suma importância na produção científica. Incentive esse hábito em seus alunos! Quanto à semelhança entre as expressões matemáticas, diga para eles que são muitas as equações na física que acabam sendo conceitualmente idênticas: embora relacionem grandezas diferentes, os conceitos envolvidos - rapidez, mudança na rapidez, energia, ímpeto (= força, torque, pressão) são os mesmos. Se achar conveniente, no intuito de ilustrar essa ideia, mostre outras equações da física onde essa equivalência está presente. A equação do trabalho de uma força e o trabalho de um gás; a lei da Gravitação Universal e a lei de Coulomb são exemplos. Ainda que algumas dessas equações não sejam reconhecidas, a ideia é ilustrar a semelhança entre os modelos matemáticos da física. Mais adiante, neste mesmo texto, daremos outros exemplos comparando os momentos (linear e angular) e as energias cinéticas de translação e de rotação. O mais importante nessa etapa de nossa explanação é chamar a atenção de seus alunos com respeito ao produto $m \cdot r^{2}$. Ele tem a ver com a resposta que procuramos. Peça a eles que memorizem esse termo! Vamos precisar que eles se lembrem desse produto mais adiante, pois ele irá reaparecer em outro contexto. 
Se procedermos de forma semelhante àquela desenvolvida anteriormente quando fizemos $F_{R}=0$, veremos que alguma outra coisa também é conservada!

Vejamos. Vamos supor que num sistema físico qualquer - mas agora em equilíbrio dinâmico, portanto em movimento circular uniforme - o torque resultante $\tau_{R}$ seja nulo. Usaremos a "nova expressão" que contém a aceleração angular para o torque. Matematicamente, em módulo,

$$
\tau_{R}=0 \Rightarrow m \cdot r^{2} \cdot \alpha=0 \Rightarrow m \cdot r^{2} \cdot \frac{\Delta \omega}{\Delta t}=0
$$

Multiplicando por $\Delta t$ ambos os lados da igualdade acima temos:

$$
m \cdot r^{2} \cdot \Delta \omega=0 \Rightarrow m \cdot r^{2} \cdot\left(\omega-\omega_{0}\right)=0 \Rightarrow m \cdot r^{2} \cdot \omega=m \cdot r^{2} \cdot \omega_{0}=\text { constante }
$$

Isso é evidente, já que não há mudança da velocidade angular no movimento circular uniforme. Entretanto, em nossos dois exemplos - terceira modificação da experiência com a borracha e na $2^{\mathrm{a}}$ lei de Kepler - há mudança da velocidade ( $v$ ou $\omega$ ) acompanhada da mudança de $r$ (distância). Repare: o termo que acabamos de destacar na expressão do torque resultante em comparação à $2^{a}$ lei de Newton contém o raio $r$. Além disso, em ambas as situações o torque resultante é nulo, o que sugere que o produto $m \cdot r^{2} \cdot \omega$ seja constante. Aqui está a resposta que procurávamos!

Escreva no quadro a equação do momento angular (em módulo): $L=m \cdot r^{2} \cdot \omega$ e peça para que os alunos comparem com a expressão $p=m \cdot v$. É provável que nesse ponto, você não precise mais colocar os parênteses no produto $m \cdot r^{2}$. Pergunte qual o nome da grandeza física que a letra $p$ está representando na segunda equação. Agora peça para que digam o nome da grandeza física que $v$ representa em comparação ao nome da grandeza física representada por $\omega$. Assim é fácil induzi-los a eleger um nome para a grandeza física denotada por $L$ na primeira expressão: Quantidade de Movimento Angular ou Momento Angular.

Aproveite este momento e compare novamente a equação do torque resultante $\tau_{R}=\left(m \cdot r^{2}\right) \cdot \alpha$ com a $2^{\text {a }}$ lei de Newton $F_{R}=m \cdot a$. Estamos tentando uniformizar a percepção conjunta de todos os nossos alunos para as equivalências conceituais das equações da física que debatemos há pouco.

Faça mais! A relação entre velocidade angular e velocidade (ou velocidade linear) é a seguinte: 


$$
\omega=\frac{v}{r}
$$

Substitua a velocidade angular $\omega$ na equação do momento angular $L$ pela relação acima:

$$
L=m \cdot r^{2} \cdot \omega=m \cdot r^{2} \cdot \frac{v}{r}
$$

Simplifique por $r$ e teremos finalmente:

$$
L=m \cdot r \cdot v
$$

Perfeito! Se $L$ é constante e $m$ não varia (para a borracha e para o planeta), então $r$ e $v$ são inversamente proporcionais: se a velocidade aumenta o raio diminui; se a velocidade diminui, o raio aumenta! Aí está a correspondência matemática dos resultados obtidos experimentalmente!

Finalmente, diga que o produto $m \cdot r^{2}$ é chamado Momento de Inércia ou Inércia Rotacional. Representaremos este momento de inércia pela letra $I$. Dessa forma, podemos representar a Quantidade de Movimento Angular de um sistema físico pela equação matemática:

$$
L=I \cdot \omega
$$

Compare-a conceitualmente com a equação da Quantidade de Movimento Linear:

$$
p=m \cdot v
$$

Vamos sintetizar e articular todas as nossas descobertas. Procure explicar todo o conteúdo do parágrafo a seguir com riqueza de detalhes e exemplos.

Equivalente ao momento linear, que permanece constante em situações onde a força resultante é nula, o momento angular é a grandeza física que se conserva quando o torque resultante é nulo. A grandeza física momento de inércia ou inércia rotacional é a grandeza angular correspondente à massa inercial: Inércia Translacional de um corpo. A associação da massa com o quadrado do raio dada pelo produto $m \cdot r^{2}$ considera a distribuição da massa de um corpo qualquer em relação a um eixo imaginário em torno do qual esse corpo poderia girar. Para uma partícula de massa $m$, distante $r$ de um eixo em torno do qual essa partícula gira, é dada exatamente por: 


$$
I_{P A R T I ́ C U L A}=m \cdot r^{2}
$$

Ao girar, o vetor posição da partícula centrado no eixo varre uma área circular. Curiosamente a área de um círculo é proporcional a $r^{2}$, como especulávamos anteriormente!

A expressão geral para o cálculo do momento de inércia de um corpo em relação a um determinado eixo é a soma dos momentos de inércia de cada partícula de massa $m_{i}$ constituinte desse corpo cuja distância $r_{i}$ é o raio descrito por cada partícula em torno desse eixo:

$$
I_{C O R P O}=\sum m_{i} \cdot r_{i}^{2}
$$

Mais adiante, ilustraremos, usando uma tabela, os momentos de inércia de alguns sólidos rígidos homogêneos.

Essa quantidade nos informa como a massa de um corpo girando se distribui em torno de um eixo de rotação. É por esse motivo que uma bailarina ou patinadora consegue modificar sua velocidade de rotação sem a necessidade de uma intervenção externa. Com os braços e/ou pernas afastados do corpo, ela gira com certo momento angular. Ao aproximar os braços e pernas do tronco, seu momento de inércia diminui, pois a distância de cada partícula de massa que compõem os seus membros aproximamse do eixo de rotação imaginado longitudinalmente ao seu tronco (figura 3.8). Como não houve nenhuma ação física externa (torque resultante nulo), simultaneamente a sua velocidade angular aumenta, permitindo que ela consiga girar mais rapidamente.

Figura 3.8. Patinadora em rodopio em torno de si mesma.
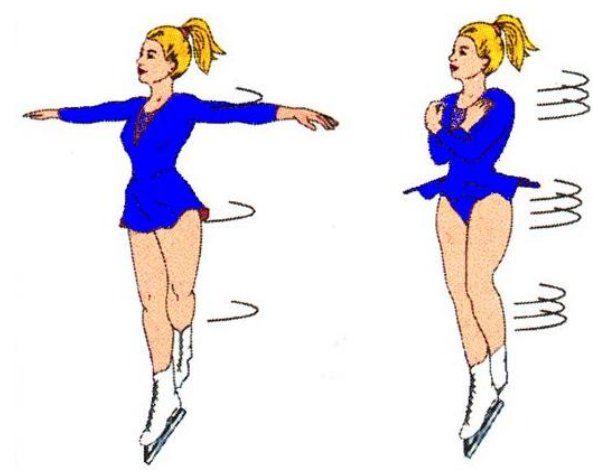

Fonte: 〈http://diadafisicacp2.blogspot.com.br/>. Acesso em: $1^{\circ}$ de outubro de 2015. 
O mesmo acontece quando um ginasta encolhe o corpo para conseguir realizar um salto mortal (figura 3.9).

Figura 3.9. Tipo de acrobacia realizada por um praticante.

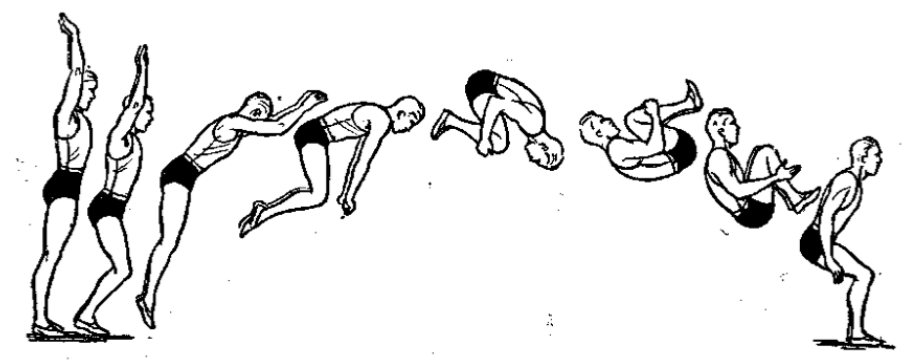

Fonte: <https://aulasdeacrobacias.wordpress.com/numero-de-acrobatas/>. Acesso em: $1^{\circ} \mathrm{de}$ outubro de 2015.

Pode parecer estranho que algo consiga aumentar a sua velocidade sem que haja a necessidade de algum impulso (torque) externo. Mas, da mesma forma que massa e velocidade de translação compensam-se nos problemas que envolvem conservação da quantidade de movimento de translação (momento linear); nas situações onde a quantidade de movimento de rotação se conserva, momento de inércia e velocidade angular também procuram se contrabalançar. Se um corpo qualquer já tiver alguma velocidade angular inicial, ele pode modificá-la bastando alterar a distribuição de massa ao longo dos limites desse corpo. É por esse motivo que ao encurtar o raio de giro, a velocidade da borracha aumentava: para conservar o momento angular do conjunto, o seu momento de inércia diminuía na mesma proporção que sua velocidade angular aumentava, já que não havia torque resultante.

\section{OUTRA EXPERIÊNCIA}

É hora de fazer outra experiência!

Será de grande contribuição se você, professor, puder realizar a experiência da cadeira giratória da figura 3.10. Chame os alunos para participarem! Se não tiver os halteres, utilize garrafas de refrigerante de um litro cheias de água. Certamente a cadeira e as garrafas são de fácil obtenção. 
Figura 3.10. Experiência da cadeira giratória com os alteres.
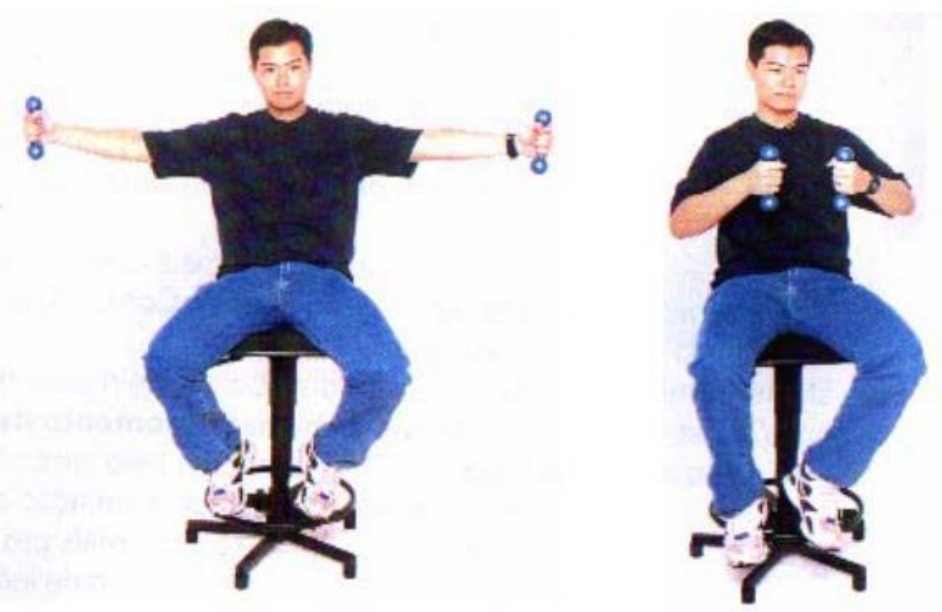

Foto: POMPEU/STUDIO 47. Fonte: TORRES, Física Ciência e Tecnologia, v.1, $3^{\mathrm{a}}$ ed., p. 210.

Peça aos alunos que tentem explicar os resultados obtidos respondendo as seguintes perguntas (fonte: GREF, disponível em <http://www.if.usp.br/gref/mec/mec1.pdf>. Acesso em: $1^{\circ}$ de outubro de 2015):

1. Por que a velocidade aumenta quando se encolhe os braços?

2. O momento de inércia é maior quando se usa halteres (garrafas de refrigerante)? Por quê?

3. Uma pessoa inicia o giro com $1 \mathrm{rad} / \mathrm{s}$ de velocidade e $3 \mathrm{~kg} \cdot \mathrm{m}^{2}$ de momento de inércia. Quando se encolhe, fica com $1,5 \mathrm{~kg} \cdot \mathrm{m}^{2}$ de momento de inércia. Qual será sua velocidade angular?

\section{LEIS DE NEWTON PARA A ROTAÇÃO}

Finalmente enunciamos a Lei da Conservação do Momento Angular:

"Em um sistema isolado, a quantidade de movimento angular total se conserva."

Essa afirmação nada mais é do a $1^{\mathrm{a}}$ lei de Newton para a rotação.

"Se o torque resultante das forças externas exercidas sobre um corpo for nulo, seu momento angular permanece constante: se já estiver parado, permanece parado; se já estiver em movimento de rotação, permanece em rotação.”

Finalmente conseguimos explicar porque a bola de basquete tende a permanecer em equilíbrio sobre o dedo quanto está girando. Ela não cai porque, por inércia, um 
objeto tende a manter também o seu movimento de rotação. Quanto maior for a sua velocidade, maior será o seu momento angular. Logo, com um momento angular maior, maior também será o torque externo necessário para alterar o movimento de rotação da bola. Claro que por causa do atrito com o dedo e com o ar (força e torque externos), a bola irá perdendo velocidade. Por esse motivo, o que precisamos fazer para manter a bola em equilíbrio é também aplicar um torque externo - com nossa outra mão - de modo a tentar "realimentar" o seu momento angular.

A $2^{\mathrm{a}}$ lei de Newton para rotação fica então:

"O torque resultante associado às forças externas que atuam sobre um corpo rígido é igual ao produto do momento de inércia desse corpo pela sua aceleração angular."

Se existem a $1^{\mathrm{a}}$ e a $2^{\mathrm{a}}$ leis de Newton para as rotações, abaixo está $3^{\mathrm{a}}$ lei de Newton para as rotações:

"Se um corpo A exerce um torque sobre um corpo B, o corpo B exerce sobre A um torque de mesmo módulo, mas de sentido contrário."

E há inúmeras situações onde essa última afirmação se revela! Quando um liquidificador, por exemplo, está desligado o momento angular é nulo, pois não há movimento de rotação. Quando ligamos o aparelho, as lâminas do triturador são acionadas pelo motor elétrico. Surge um torque interno que provoca a alteração da quantidade de movimento angular de uma das partes do equipamento. Imediatamente, outro torque interno tende a fazer com que a base e o copo do liquidificador tentem girar no sentido oposto ao da rotação das lâminas. Não percebemos essa rotação porque o copo está bem fixo à base, e esta por sua vez, apoiada sobre uma superfície cujo atrito é suficiente para não deixar o conjunto deslizar. Se a superfície de apoio estivesse livre de atrito, veríamos o liquidificar girar enquanto estivesse ligado! Isso não é diferente para qualquer eletrodoméstico que disponha de um motor que provoque movimentos de rotação. Batedeiras, espremedores de frutas, máquinas de lavar, enceradeiras. Até mesmo ventiladores poderiam girar se não estivessem apoiados a uma superfície ou aparafusados a algum suporte.

Para entender isso melhor, faça com que seus alunos se lembrem de situações já estudadas que envolviam a conservação da quantidade de movimento linear. É possível que o professor tenha trabalhado junto aos alunos, exercícios onde a quantidade de movimento total de um sistema físico isolado era igual a zero. Nestes casos, sempre apareciam, em partes diferentes do sistema físico, movimentos simultâneos e em 
sentidos opostos. Aqui não é diferente (conceitualmente). Rigorosamente, diferença há, pois a quantidade de movimento agora é angular. Dessa forma, surgem rotações de mesma quantidade de movimento angular, porém em sentidos contrários. Se suspendêssemos esses equipamentos, perceberíamos isso. Faça uma comparação novamente com a conservação do momento linear: uma arma, que suspensa por um fio dispara um projétil, sofre um recuo no sentido oposto. Claro que a rapidez de recuo da arma é bem menor que a velocidade de avanço do projétil. Aqui também não é diferente! Se o liquidificador pudesse girar livremente, pergunte aos seus alunos o que eles poderiam afirmar ao comparar essa rapidez de rotação da carcaça em relação à frequência de giro das lâminas que trituram os alimentos. Peça para que os alunos reconheçam outras situações similares a essas. Em suma, o que é preciso entender é que se algo gira para um lado, alguma outra coisa tende a girar no sentido contrário.

Há outro exemplo bem-humorado (e exagerado) em um dos episódios do desenho Os Simpsons no YouTube com o título "Science in Simpsons (Conservation of Momentum)" acessível através do link: <https://www.youtube.com/watch?v=6DiY5J2$\underline{\mathrm{RKg}}$ >. Acesso em: $1^{\mathrm{o}}$ de outubro de 2015.

Caso o professor não disponha de TV ou projetor digital no espaço da sala de aula, peça para que seus alunos visualizem o vídeo em seus celulares. Hoje em dia, quase todo mundo tem celular...

Por fim, peça para algum aluno sentar na cadeira giratória novamente e, sem que ele apoie os seus pés no chão, tente girar o corpo em qualquer sentido. Incentive os demais alunos a tentarem responder por que ele tem dificuldades em fazê-lo.

\section{MOMENTOS DE INÉRCIA}

Abaixo, figura 3.11, encontra-se uma tabela que identifica os momentos de inércia de vários corpos que possuem certa simetria em relação a determinados eixos. Compare os valores de I para os diversos corpos, observando como a distribuição de massa em torno do eixo determina o momento de inércia de cada um. 
Figura 3.11. Momentos de inércia de alguns sólidos homogêneos.

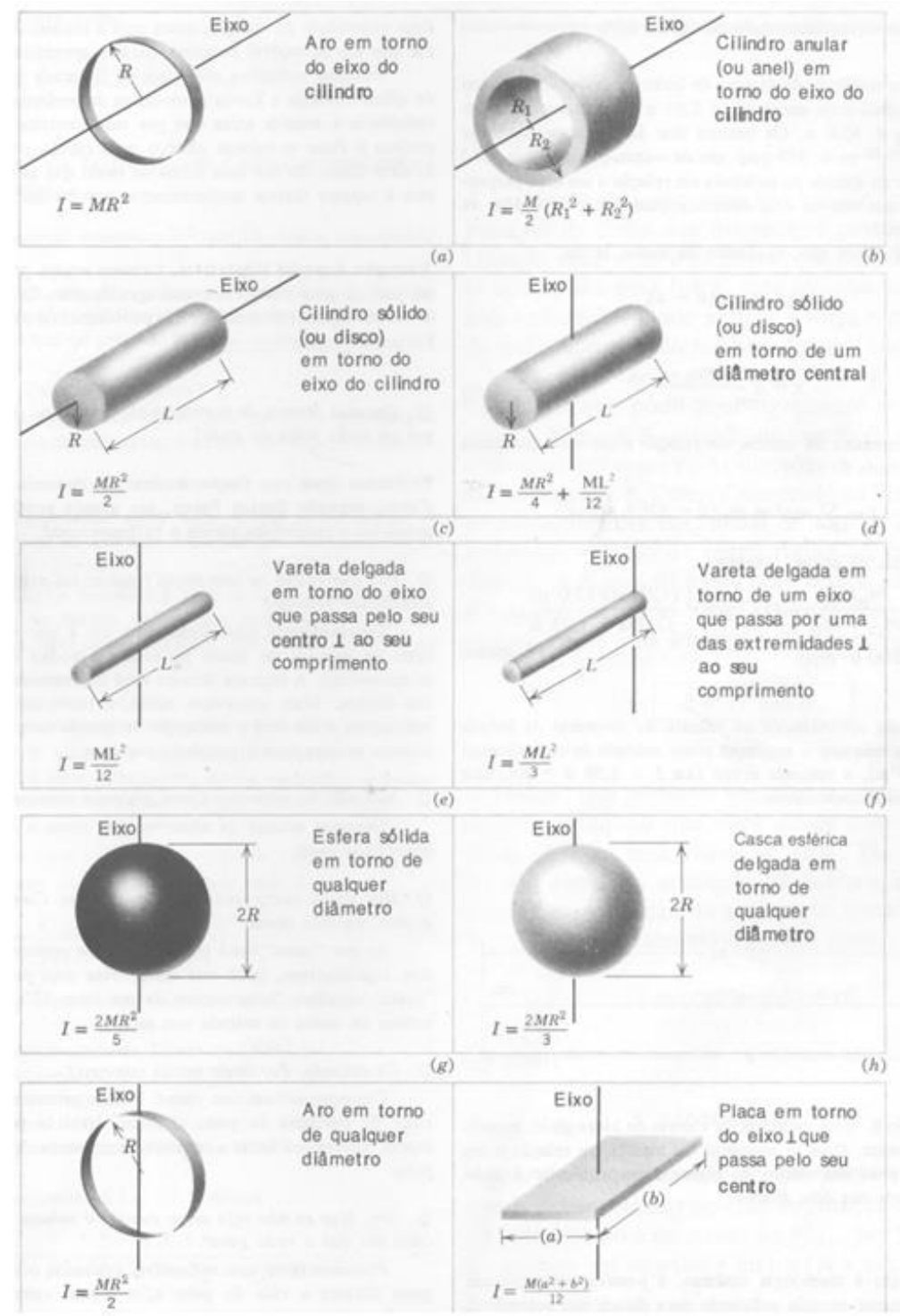

Fonte: HALLIDAY e RESNICK, Fundamentos da Física 1, v.1, 1ª ed., p. 223.

Observe que os momentos de inércia dos vários corpos acima são todos iguais a uma fração do momento de inércia do aro em torno de um eixo cilíndrico (figura 3.11 (a)). Por quê? Repare que cada momento de inércia é proporcionalmente menor quanto maior forem as porções de massa próximas ao eixo de rotação. Se todas as partículas que constituíssem um corpo qualquer estivessem à mesma distância do eixo de rotação, o momento de inércia desse corpo seria exatamente igual àquele de uma partícula de mesma massa $M$ do corpo e distância $R$ ao eixo de rotação, portanto: $M \cdot R^{2}$. Este resultado é compatível à simetria na distribuição de massa em torno do eixo de referência. A outra conclusão que tiramos dessas observações - e agora pelo resultado matemático - é que a mesma massa, dependendo de sua distribuição, acarreta diferentes 
momentos de inércia. Recorde seus alunos: lembram-se de que a quantidade de massa de um corpo media a quantidade de inércia do mesmo? E que tal quantidade de inércia estava relacionada a uma espécie de resistência à mudança no estado de repouso e movimento? Pois bem, o momento de inércia também mede uma resistência, mas em relação a um movimento de rotação. Quanto maior for o momento de inércia de um corpo em relação a um determinado eixo, maior será o torque necessário para fazê-lo girar em torno desse eixo e, de forma equivalente, tanto menor será a velocidade angular com a qual ele conseguirá girar. É fácil perceber e concordar com isso: tente girar uma vareta segurando-a próxima de uma de suas extremidades e compare com o esforço de girá-la com a sua mão próxima do centro. Dançar na chuva com o guarda-chuva aberto não é o mesmo que dançar sem chuva com o guarda-chuva fechado. E não estamos falando de resistências passivas!

Por fim, caso o professor disponha de mais tempo e/ou haja maior interesse dos alunos pelo tema em voga, há um roteiro de atividades utilizando material de baixo custo e de fácil confecção, no compêndio 'Leituras de Física', Mecânica, capítulo 10, pág. 37, desenvolvido pelo GREF e disponível em PDF para download pelo link: $\left\langle\right.$ http://www.if.usp.br/gref/mec/mec1.pdf $>$. Acesso em: $1^{\circ}$ de outubro de 2015.

Podem-se utilizar latas de alumínio ao invés dos potinhos de filme fotográfico, que são muito incomuns em nossos tempos modernos.

\section{EXISTE TAMBÉM ENERGIA DE ROTAÇÃO?}

De posse dos conceitos de momento angular e momento de inércia, podemos agora fazer um estudo mais fidedigno dos movimentos. Quando se estudou lançamentos (vertical, horizontal, oblíquo) sempre fomos levados a considerar os objetos como pontos materiais. E sob esse modelo, os objetos executavam exclusivamente movimentos de translação: todos os pontos do corpo descreviam trajetórias paralelas. Não considerávamos as possíveis rotações que poderiam ocorrer nos corpos enquanto se movimentavam. Não é à toa que os professores de física desenham os objetos em problemas de diagramas de corpo livre como blocos, não como esferas - com exceção para os casos de esferas penduradas por fios. Pode ser que seu aluno ainda não tenha pensado nisso: uma bola só pode descer um plano inclinado deslizando se não houver atrito entre esta bola e o plano! Em grande parte dos exercícios resolvidos ao longo do ano letivo, o atrito era desprezado. Se houvesse atrito, parte da energia cinética da bola ao descer a rampa estaria relacionada ao seu movimento de rotação. Ou seja, na 
realidade existem dois tipos de energia cinética. É sobre isso que começaremos a debater agora.

\section{ENERGIA CINÉTICA DE TRANSLAÇÃO E ROTAÇÃO}

Falar da velocidade (linear) de um disco (um CD ou um DVD, por exemplo) que gira com o seu centro fixo sobre uma plataforma parece não fazer sentido ao menos por dois motivos: primeiro, o disco não apresenta movimento de translação; segundo, cada ponto do disco apresenta velocidade (linear) diferente. Por esse motivo, não há como caracterizar o movimento de rotação do disco pela velocidade linear. Essa argumentação justifica a criação de uma velocidade para caracterizar o movimento do disco. Poder-seia usar esse contexto para justificar o conceito de velocidade angular, por exemplo. Nos livros de ensino médio, de forma geral, com exceção do capítulo e dos exercícios que tratavam do equilíbrio de corpos extensos, todos os demais consideravam os corpos como partículas. Suas posições e velocidades sempre eram referentes aos seus centros de massa. Ora, o centro de massa do disco mencionado não gira. Não tem velocidade. Nem angular, nem linear. Dessa forma, se fosse tratado como partícula, tal objeto não deveria ter energia cinética.

Vamos nos lembrar da equação para o cálculo da energia cinética:

$$
E_{C}=\frac{1}{2} m v^{2}
$$

Mas o disco tem movimento! Se a energia cinética é a energia relacionada ao movimento, como podemos dizer que ele não tem energia cinética se ele gira? De fato, o disco não é uma partícula, mas constituído por uma infinidade delas. Com exceção daquela posicionada exatamente no seu centro, todas as demais têm velocidade, portanto, têm energia cinética. Vamos somar todas essas energias cinéticas. 
Figura 3.12. Objeto rígido em rotação em torno de um eixo que passa pelo ponto $O$.

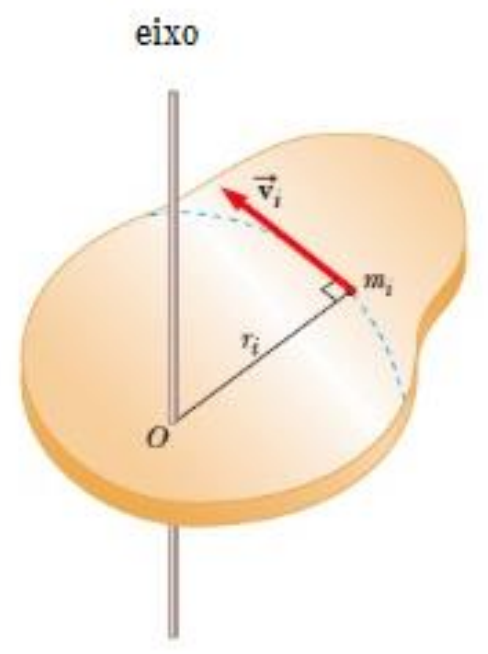

Fonte: <http://slideplayer.com.br/slide/328427/>. Acesso em: $1^{\circ}$ de outubro de 2015.

Tomemos como base de compreensão a figura 3.12. Cada partícula do corpo de massa $m_{i}$ em rotação movimenta-se com velocidade $\vec{v}_{i}$. A velocidade de cada uma depende da distância ao centro de rotação do disco. Todas as partículas, no entanto, compartilham da mesma velocidade angular $\omega$, pois consideramos o disco como um corpo rígido. Como $v=\omega r$, então, para cada partícula temos que $v_{i}=\omega r_{i}$. A energia cinética de cada partícula é dada por:

$$
E_{C_{P A R T I ́ C U L A}}=E_{C_{i}}=\frac{1}{2} m_{i} v_{i}^{2}=\frac{1}{2} m_{i} \omega^{2} r_{i}^{2}
$$

Somando a energia cinética de todas as partículas que constituem o disco, temos:

$$
E_{C_{D I S C O}}=\sum E_{P A R T I ́ C U L A}=\sum E_{C_{i}}=\sum \frac{1}{2} m_{i} \omega^{2} r_{i}^{2}=\frac{1}{2} \omega^{2} \sum m_{i} r_{i}^{2}
$$

Pergunte ao seu aluno se ele reconhece o termo $\sum m_{i} r_{i}^{2}$ da equação acima. Trata-se da expressão para o cálculo do momento de inércia de um corpo!

No caso do disco, o seu momento de inércia é dado por

$$
I_{D I S C O}=\sum m_{i} r_{i}^{2}
$$

Reescrevendo a expressão da energia cinética do disco: 


$$
E_{C_{D I S C O}}=\frac{1}{2} \omega^{2} I_{D I S C O}
$$

De forma geral, a energia cinética de rotação de um corpo que gira é dada por:

$$
E_{C}=\frac{1}{2} I \omega^{2}
$$

Peça para que seus alunos comparem a expressão acima com a conhecida equação da energia cinética dos capítulos de conservação da energia mecânica dos livros. Novamente, as equações são parecidas porque são conceitualmente idênticas. Embora sejam parecidas, não são iguais, pois representam energias de movimento relacionadas a tipos de movimentos diferentes. Não são espécies diferentes de energia. Ambas são energias cinéticas expressas em formas convenientes a cada contexto. Em resumo, se um corpo tem movimento de translação, ele tem energia cinética de translação; se um corpo tem movimento de rotação, ele tem energia cinética de rotação; se um corpo tem movimento de translação e movimento de rotação, ele tem as duas!

Esse é um momento importante para que o professor possa revisar e comparar a resolução de problemas que envolviam a conservação da energia mecânica quando objetos eram lançados de uma altura à outra sob a ação exclusiva do campo gravitacional. Pode ser que eles se lembrem de objetos que eram lançados pelo impulso causado por molas previamente comprimidas. Nesse último caso, comente e revise com seus alunos que a energia potencial elástica armazenada na mola era convertida em energia cinética e, em sequência, em energia potencial gravitacional após o corpo ser lançado. Na época, a energia cinética era exclusivamente energia de translação. A partir de agora, entende-se que enquanto viaja, o objeto pode fazê-lo girando em torno do seu centro de massa. Dessa forma, o objeto em questão possuirá tanto energia cinética de translação quanto energia cinética de rotação.

Pergunte a eles quem atingiria primeiro a base de uma rampa, caso partissem de uma mesma altura: uma bola que desliza numa rampa sem atrito ou uma bola que rola rampa abaixo com atrito? É provável que eles respondam que é a bola da primeira situação. Mas pergunte por que eles afirmaram isso. É igualmente provável que eles respondam que a segunda bola demora mais porque há atrito. Isso não está errado de forma alguma! Mas tente fazê-los entenderem o motivo que, relacionado ao tema debatido, está levando você, professor, a fazer tal pergunta. A resposta esperada está 
relacionada à conversão de energia potencial gravitacional inicial em energia cinética de translação no primeiro caso, e energia cinética de translação e rotação no segundo caso. Peça para que seus alunos pensem a respeito da seguinte questão. A altura atingida por uma bola de futebol é sempre a mesma, independente se ela subir girando ou não? De outra forma, se a bola for lançada do solo em duas situações dispondo da mesma energia cinética de translação, ela alcançara a mesma altura se subir girando ou não? Deixe que eles elaborem as suas respostas.

Para finalizar, coloque em debate o seguinte trecho retirado do site da internet: <http://polifutebol.blogspot.com.br/2012/11/a-arte-do-futebol-cobranca-de-falta.html >. Acesso em: $1^{\circ}$ de outubro de 2015.

"O inglês Ken Bray, físico da Universidade de Bath, publicou em 2009 um livro chamado How to Score: Science and Beautiful Game, que tenta explicar o futebol através da ciência. O trecho do livro que fala sobre as cobranças de faltas afirma que o brasileiro Juninho 'Pernambucano' é o melhor batedor de faltas da história do futebol.”

O físico afirma que Juninho é o melhor cobrador de faltas de todos os tempos porque ele consegue executar com maestria todas as três diferentes técnicas utilizadas nas cobranças de faltas do futebol moderno. Em uma das técnicas, a bola é chutada quase sem curva, mas é capaz de atingir velocidades impressionantes! Para isso, Juninho afirmava treinar chutes para que a bola se deslocasse sem girar. Você saberia dizer que justificativas científicas (físicas) confirmam a afirmação de Juninho?

E caso os seus alunos queiram aprender uma técnica de como equilibrar a bola de basquete no dedo...

Texto retirado do site eHow Brasil

Disponível em: 〈http://www.ehow.com.br/girar-bola-basquete-dedos-como 160864/>. Acesso em: $1^{\circ}$ de outubro de 2015.

\section{Como girar uma bola de basquete na ponta dos dedos}


Figura 3.13. "Gire uma bola manipulando a gravidade e a velocidade."

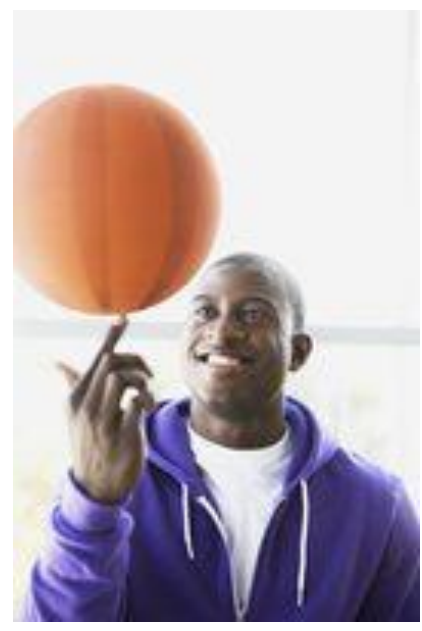

Foto: Jupiterimages/Brand X Pictures/Getty Images. Acesso em: $1^{\circ}$ de outubro de 2015.

Um público fica geralmente admirado com quem consegue girar uma bola de basquete na ponta dos dedos (figura 3.13). O truque parece desafiar a gravidade. Entretanto, depois de entender o básico, você pode executá-lo. Tudo que ele exige é o uso correto de equilíbrio e velocidade, assim como andar de bicicleta. Depois de aprender, pratique até conseguir manusear a bola e mantê-la na ponta dos seus dedos.

Instruções:

1. Segure a bola com sua mão dominante contra o seu peito. A palma deve ficar virada para você com o polegar apontando para cima.

2. Agarre a bola com a outra mão de modo que ela não repouse mais sobre o seu peito. A mão é posicionada entre a bola e o peito, em frente à mão oposta, com o polegar para baixo e a palma para fora.

3. Puxe os braços em direções opostas rapidamente. Mantenha-os nivelados em vez de puxar os cotovelos para baixo. Isso faz com que a bola gire paralela ao chão. Se a bola girar em ângulo, você não conseguirá equilibrá-la em seu dedo.

4. Lance a bola para cima conforme você a gira. Ela deve atingir a linha um pouco acima dos seus olhos.

5. Coloque o dedo médio da sua mão dominante sob a bola de basquete, posicionando-o no meio, assim que ela atingir a altura correta. Dobre um pouco o dedo e traga a bola para baixo, próximo ao seu peito.

6. Gire a bola com a mão oposta. Quanto mais rápido ela girar, melhor você pode mantê-la sob controle. 


\section{QUESTÕES DE VESTIBULARES}

1. (UFRN 99) Com a mão, Jorge está girando sobre sua cabeça, em um plano horizontal, um barbante que tem uma pedra amarrada na outra extremidade, conforme se vê na figura ao lado. Num dado momento, ele para de impulsionar o barbante e, ao mesmo tempo, estica o braço da mão que segura o barbante, não mexendo mais na posição da mão, até o fio enrolar-se todo no carretel de linha. Jorge observa que a pedra gira cada vez mais rapidamente, à medida que o barbante se enrola em seu dedo. Isso pode ser explicado pelo princípio de conservação do(a)

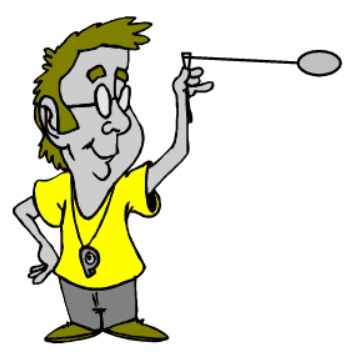
A) momento linear
B) energia mecânica
C) momento angular
D) energia total.

2. (UFRN - 98) Uma bailarina inicia uma série de rodopios com os braços bem abertos e afastados do corpo e realiza os últimos rodopios com os braços encolhidos e bem juntos do corpo. Admita que o atrito das sapatilhas da bailarina com o solo seja desprezível. Analise as afirmações abaixo e, em seguida, assinale a opção cujos números correspondem a afirmativas corretas sobre o movimento da bailarina:

I) A bailarina realiza os últimos rodopios girando mais rapidamente do que quando começou.

II) A bailarina realiza os últimos rodopios girando mais lentamente do que quando começou.

III) A mudança da velocidade de rotação é explicada pelo princípio da conservação do momento angular.

IV) A mudança da velocidade de rotação é explicada pelo princípio da conservação do momento linear.
A) I e IV
B) II e III 

C) I e III
D) II e IV

3. (UFRN 2002) Em revista de circulação nacional, uma reportagem destacou a reação da natureza às agressões realizadas pelo homem ao meio ambiente. Uma das possíveis consequências citadas na reportagem seria o derretimento das geleiras dos polos, o que provocaria uma elevação no nível do mar. Devido ao movimento de rotação da Terra, esse efeito seria especialmente sentido na região do equador, causando inundações nas cidades litorâneas que hoje estão ao nível do mar. Levando-se em conta apenas esse efeito de redistribuição da água devido ao degelo, podemos afirmar que
A) o momento de inércia da Terra, em relação ao seu eixo de rotação, aumentará.
B) a velocidade angular da Terra, em relação ao seu eixo de rotação, aumentará.
C) o período de rotação da Terra, duração do dia e da noite, diminuirá.
D) o momento angular da Terra, em relação ao seu centro de massa, diminuirá.

4. Um atleta, com os braços esticados, está girando em cima de uma mesa giratória segurando dois halteres, ambos a $60 \mathrm{~cm}$ do eixo de rotação da mesa, conforme ilustrado na figura $\mathrm{A}$, abaixo. Em seguida, ele fecha os braços à altura do peito até que os halteres sejam trazidos a $10 \mathrm{~cm}$ do eixo, como esquematizado na figura B. Considerando essas informações e desprezando o momento angular do atleta em relação ao dos halteres e qualquer força dissipativa, julgue o item seguinte.

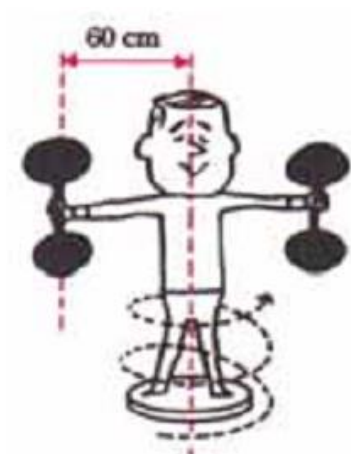

(A)

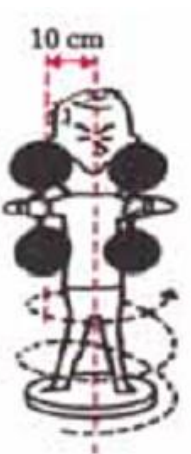

(B)

(C) (E) Na situação final, ilustrada na figura $\mathrm{B}$, a velocidade de rotação do atleta é inferior à que ele tinha na situação ilustrada na figura A.

5. (C) (E) Um ioiô que for solto por um indivíduo de uma altura qualquer, girando a partir do repouso, com a ponta de sua corda presa ao dedo do indivíduo, levará menos 
tempo para atingir o solo do que se cair em queda livre dessa mesma altura, com a ponta de sua corda solta e sem girar, visto que o movimento de rotação aumenta sua velocidade de queda.

6. (C) (E) Em uma situação como a ilustrada na figura abaixo, em que se supõe que as roldanas A e B tenham a mesma massa e o movimento ocorra sem deslizamento, o módulo da velocidade angular dessas duas roldanas é o mesmo, assim como são iguais suas energias cinéticas.

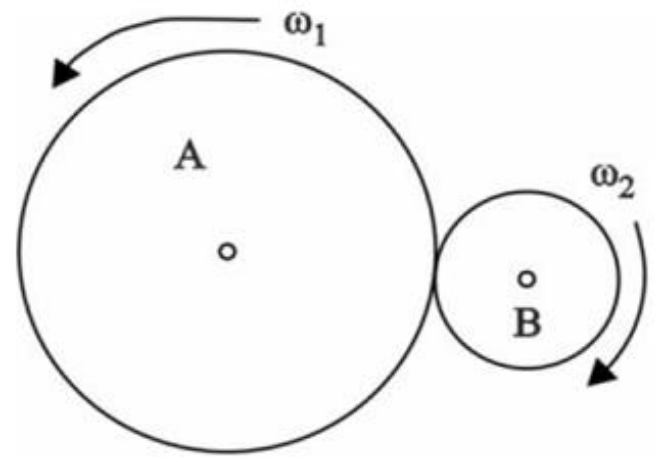

7. (C) (E) O momento angular de Marte, em seu movimento de rotação ao redor do Sol, tem o mesmo valor, em módulo, tanto no afélio quanto no periélio.

8. (C) (E) A estabilidade da trajetória de um ciclista é função da intensidade e da conservação do momento angular.

\section{GABARITO}

1. $\mathrm{C}$

2. $\mathrm{C}$

3. $\mathrm{A}$

4. $\mathrm{E}$

5. $\mathrm{E}$

6. $\mathrm{E}$

7. $\mathrm{C}$

8. $\mathrm{C}$ 


\section{Capítulo 4}

\section{Refletindo sobre o ensino de Conservação do Momento Angular: críticas e sugestões à proposta}

\subsection{Introdução}

As discussões apresentadas neste capítulo foram desenvolvidas mediante as críticas, opiniões e respostas fornecidas pelos professores-sujeitos desta pesquisa, que passo a apresentar em sua totalidade e nos termos que eles se posicionaram. Algumas passagens foram extraídas das falas e outras de escritos produzidos pelos próprios professores. As entrevistas semiestruturadas foram guiadas por quatro apontamentos, a saber, a) sobre o potencial pedagógico do produto educacional analisado e avaliado; b) sobre o rigor técnico matemático e conceitual e as possibilidades de inovação pedagógica a partir da proposta; c) sobre a natureza de a proposta ter características de roteiro fechado e com pouco espaço de intervenção do professor; d) sobre as motivações do professor com relação ao uso da proposta em face às possíveis dificuldades em aplicá-lo em sala de aula ou equivalente.

\subsection{Sobre o potencial pedagógico do produto educacional analisado e avaliado}

A intenção aqui foi obter as opiniões e críticas dos professores acerca da real possibilidade do produto educacional produzido ser aplicado em uma turma de ensino médio da escola pública, considerando, principalmente, a frequente heterogeneidade dos alunos que compõem as turmas. Em caso de incoerências, inadequações e fragilidades da proposta, quais modificações seriam exigidas para sua implementação na sala de aula?

Todos os sujeitos concordaram que não havia necessidade de mudanças significativas textuais quanto à apresentação e desenvolvimento das ideias originais da proposta didática.

“O material pode ser utilizado da forma em que foi apresentado. Destaco como pontos positivos do material as possibilidades de analogias entre variadas situações físicas, o potencial efetivo para explorar situações do dia a dia e boa correspondência entre as questões ao final e o texto didático." (Sujeito A). 
“É possivel de ser aplicado como está. Acredito que é aplicável ao ensino médio de maneira precisa e eficiente. O texto ficou claro, os exemplos são de fácil entendimento e completam de maneira coesa com a teoria proposta. (...) os exemplos são simples e muito diretos." (Sujeito B).

"O material proposto é rico em informações que subsidiam o trabalho do professor interessado em ministrar o assunto em suas turmas de $1^{\circ}$ ano." (Sujeito C).

Embora o sujeito C tenha elogiado de forma genérica o conteúdo da proposta, ele também aponta ressalvas e cuidados quanto às condições de sua aplicabilidade em quaisquer turmas, indistintamente, como se verifica na passagem abaixo:

"Sobre ser abordado na forma em que está, dependerá do público alvo e das condições que a escola dará ao professor, pois não é um assunto costumeiramente apresentado nos conteúdos e currículos escolares. Penso que dispondo de tempo adicional e uma turma com pré-requisitos matemáticos e conceituais o material se adéqua. A crítica que posso tecer é no sentido de ser um material que aborda um tema interessante, mas que, na forma que é proposto, não se faz possível de ser ensinado em turmas menos "preparadas". Ou seja, acaba sendo um material destinado a professores muito competentes e turmas (de ensino médio) muito avançadas." (Sujeito C).

Entendem-se como turmas "menos preparadas" aquelas que carecem dos prérequisitos necessários (matemáticos e relacionados à física) para o bom desenvolvimento das ideias produzidas no desenrolar da argumentação. Não obstante o material abordar um tema que seja interessante observa o sujeito $C$, a sua aplicação direta não se faz possível sem tais pré-requisitos. É evidente em sua fala o olhar teórico de Ausubel, segundo o qual, um conhecimento prévio subjaz uma aprendizagem significativa. De fato, e ainda numa perspectiva ausubeliana, estamos interessados em uma aprendizagem que permita ao aluno "adquirir e armazenar a vasta quantidade de ideias e informações representadas em qualquer campo de conhecimento" (AUSUBEL apud MOREIRA, 2009). Repare o leitor que o discurso do sujeito C não é só direcionado ao aluno, como também ao professor que se utiliza do material. Caso este último também não disponha dos conhecimentos prévios e perícia em suas atribuições, a compreensão, e menos ainda a aplicação do material em sala de aula tende a não ter 
êxito. De acordo com os dados da pesquisa de Silva (2012), um terço dos professores entrevistados não tinha formação em Licenciatura em Física. Esta informação parece ainda antagonizar com Moreira apud Silva (2012, p. 18), presente no mesmo trabalho.

Como os alunos de hoje serão os docentes de amanhã, tem-se tentado reformular o ensino nas graduações de modo que os profissionais formados, independentemente de sua área de atuação, sejam capazes de abordar e tratar os problemas novos e tradicionais e que estejam sempre em busca de novas formas do saber científico ou tecnológico.

Contudo, apenas sob este aspecto - imperícia do professor - concordo haver relação entre a implementação ou não do material e a verificação pouco comum do assunto no currículo da educação básica. A meu ver, não há relação entre a aplicabilidade do material e a pertinência do assunto nos currículos preexistentes. Com efeito, o fato de o professor estar ou não familiarizado com o assunto a ser lecionado incide diretamente sobre sua capacidade de discursar com maestria sobre o mesmo. Se o professor dispuser de tais habilidades, o estudo da lei de Conservação do Momento Angular (CMA), nos termos que foi apresentado na proposta didática, será como o estudo de qualquer outro assunto já trabalhado há anos em nossos currículos escolares tradicionais.

A teoria ausubeliana também foi notada nos trabalho de Carvalho e Villani (1996), porquanto as concepções prévias dos estudantes entrevistados serviram como ponto de partida para explicar as regularidades dos fenômenos observados. Subjacentes aos comentários do sujeito $\mathrm{C}$, o caminho que precisaria ser percorrido cognitivamente pelos alunos a partir de seus conhecimentos prévios rumo a novos conhecimentos relacionados aos primeiros, são distintos daqueles vistos no trabalho de Carvalho e Villani (1996). Curiosamente tais conhecimentos prévios foram utilizados na ressignificação de certos conceitos anteriores que não se coadunavam com a visão científica. Verifica-se então uma intrigante dupla prerrogativa dos subsunçores já existentes no educando: são igualmente profícuos na apreensão de novos conhecimentos, quer esses novos conhecimentos sejam eles semelhantes, quer esses novos conhecimentos estejam apenas relacionados às preconcepções já existentes. Tais constatações parecem dar ainda mais sustentação à teoria cognitivista de Ausubel.

O sujeito A destaca uma importante observação sobre a valorização da troca de ideias entre os atores do processo educacional promovida pela participação ativa dos alunos quando da realização das experiências. 
“Como pontos positivos, destaco a preocupação do autor em inserir o estudante como polo ativo do processo educacional fazendo com que haja o intercâmbio de ideias e o debate dos conceitos físicos do experimento em questão, além de correlacionar o fenômeno com situações do dia a dia." (Sujeito A).

A argumentação acima corrobora a visão de Heckler (2004, p. 9):

Com este material conseguimos desenvolver os conteúdos de uma forma mais atrativa, com maior envolvimento dos alunos e maior motivação por parte dos mesmos, fazendo com que se sentissem participantes ativos na aquisição de informações e construção do conhecimento.

Heckler $(2004$, p. 11) enfatiza “[...] a necessidade de mudança da postura e da organização da escola, frente a um modelo tradicional de ensino e um novo modelo construtivista colaborativo". Por certo, acredito que a participação do aluno em diversos momentos durante as experiências auxilia não apenas no seu envolvimento com relação às propostas de ensino na escola, como também contribui na produção do interesse decorrente de sua interação com o objeto em estudo. Acredito que atividades lúdicas experimentais sempre são bem vindas quando bem direcionadas.

De mesma opinião, a ludicidade atrelada às experiências é ponto positivo no comentário do sujeito D. Segundo ele, a problematização gerada a partir das observações rendem frutos na conexão entre matemática e experimentação.

“Achei os experimentos propostos bem lúdicos, que geram bastante problematização, sendo que mais tarde são respondidos de forma matemática, o que facilita a compreensão de fenômenos de rotação, pois há uma junção da parte experimental e matemática." (Sujeito D).

A questão da ludicidade e a experimentação prática, aspectos presentes e enlevados pelos sujeitos da pesquisa ao longo de suas apreciações frente à proposta didática, também aparecem em destaque nos trabalhos de Carvalho e Villani (1996) e Würs (2012). Demonstrações experimentais aquinhoadas de ações lúdicas e interativas, como são aquelas evidenciadas no produto em análise, são promotoras de um ensino contextualizado e instigante, que incentiva à participação dos alunos e assevera uma aprendizagem mais significativa. 
Contudo, o material carece ainda de uma quantidade maior de ilustrações que, sem dúvida, auxiliariam bastante não só na visualização, mas também no entendimento da argumentação textual. Esse foi um dos apontamentos do sujeito A:

"Como sugestão, proponho maior número de ilustrações acompanhando o texto a fim de que os raciocínios fiquem mais esclarecedores." (Sujeito A).

Além dessa sugestão, o sujeito A também recomenda a confecção um quadro comparativo entre as grandezas e equações do movimento de translação e do movimento de rotação, a exemplo de Kantor et. al. (2013). Considerações como estas certamente serão contempladas na revisão final do produto educacional, reelaborado para além do escopo desse trabalho.

\subsection{Sobre o rigor técnico matemático e conceitual e as possibilidades de inovação pedagógica a partir da proposta}

Aqui, o propósito foi de apontar primeiro se de fato existe um rigor técnico matemático e conceitual exagerados no material em análise. Diante desse aspecto, e caso o professor tenha conhecimento de outras propostas similares, em que pontos o produto educacional gerado se aproxima ou se afasta das outras já existentes? Finalmente, em função das percepções e experiências de magistério do sujeito entrevistado, qual a viabilidade do assunto abordado fazer parte ou não do currículo da educação básica.

Acerca do pressuposto rigor matemático, segue abaixo o que dois dos sujeitos da pesquisa têm a dizer.

“O conteúdo apresenta-se complexo em suas ideias, embora sua descrição matemática contenha variáveis comumente enfatizadas da mecânica: velocidade, distância, torque, força, momento linear. Contudo, outras grandezas, como momento de inércia, momento angular e sua conservação podem parecer complexas tendo em vista as distintas metodologias de cálculo envolvendo o conceito de momento de inércia para corpos de diversas geometrias." (Sujeito A). 
"O rigor matemático se mantém preciso, dentro dos limites impostos pelo currículo de matemática do ensino médio." (Sujeito C).

Ao concordar com o sujeito $\mathrm{C}$, destaco que o material foi inteiramente elaborado pressupondo apenas conhecimentos da matemática comumente ensinada nas escolas de nível médio do país. No interior desse currículo escolar, os assuntos mais explorados em minha proposta pedagógica são relações de direta e inversa proporcionalidade e resolução de equações polinomiais de $1^{\circ}$ grau, sem os quais corre-se o risco do não entendimento das novas equações físicas, que por sua vez, só se estabelecem a partir destes elementos matemáticos. Resgatando o que já foi dito na seção 3.5, é preciso assegurar que os alunos possuam mínima desenvoltura nestes pré-requisitos básicos.

Recuperando os comentários do sujeito A, sobre o cálculo do momento inércia para diversas geometrias, o material traz apenas os resultados, sem efetuar as operações que conduzem a obtenção daqueles. O que há de interessante, e aqui defendo a proposta, é a discussão impulsionada a partir da comparação dos valores diversos de momento de inércia. Congruente aos requisitos matemáticos mencionados acima, a compreensão do que seja uma proporcionalidade permitirá ao aluno relacionar os valores de cada momento de inércia com as características físicas de cada corpo, em especial, à forma com a qual a massa se distribui nos limites desse corpo. Na realidade, a compreensão de que o resultado obtido pela multiplicação de um número qualquer por uma fração é, necessariamente, um produto menor que o primeiro número, já seria suficiente para o aluno compreender a comparação entre os diversos momentos de inércia apresentados na figura 3.11.

Ainda com relação ao rigor matemático, sobretudo ao tratamento vetorial que é evitado pela proposta pedagógica, os sujeitos alegam o seguinte:

“Acho adequado a nível de ensino médio não efetuar esse tipo de viés vetorial, pois nos livros secundaristas isso não é comum. Sem falar que esse tipo de abordagem faz com que os rigores matemáticos sejam assaz sofisticados. Ademais, seria uma forma de evitar definições do tipo produto escalar e vetorial." (Sujeito A).

"Vejo que o material pode ser uma boa transposição didática para o ensino médio. As grandezas angulares não precisam ser tratadas de forma vetorial, pois para 
compreensão de um aluno de ensino médio se tornaria muito complicado por não ter um bom embasamento matemático." (Sujeito D).

"Nos moldes que a proposta foi elaborada, penso que não foi necessário, pois o nível de abordagem adequou-se ao dos alunos, sem prejuízo da compreensão do tema ensinado." (Sujeito C).

Em consonância a minha escolha e à proposta de Kantor et. al. (2013), o tratamento vetorial das grandezas angulares pode ser dispensado, não comprometendo a compreensão física dos fenômenos investigados e outros análogos a eles. Acrescente-se a estas opiniões a obra de Gaspar (2010), que embora não tenha sido alvo de análise deste trabalho, serviu de auxílio na elaboração do produto educacional. Na contramão destas preferências ou opções, destacam-se a obra de Torres et. al. (2013) e o material do GREF direcionado para o professor. Chamo atenção do leitor para que não confunda este último, publicado em papel pela Editora da Universidade de São Paulo (Edusp), daquele disponível para download através do site http://www.if.usp.br/gref/ direcionado, por sua vez, ao aluno e demais interessados. O primeiro fornece o devido tratamento vetorial a todas as grandezas angulares, o que possibilita dessa forma exemplificar e explicar uma quantidade muito maior de situações físicas. O segundo, destinado aos alunos, comenta brevemente a necessidade de representar o sentido de uma rotação pela regra da mão direita, contudo, sem usar o vocabulário das grandezas vetoriais $^{8}$.

Não diretamente em relação à matemática (embora incida sobre ela), mas com respeito ao aspecto de sequenciamento de raciocínios, uma característica bastante explorada em todo o texto didático merece ser ressaltada, segundo o sujeito A. Para ele, o raciocínio dedutivo é explorado no encadeamento das ideias na totalidade do texto didático. A possibilidade de derivar outras explicações e previsões além daquelas obtidas por via direta da observação é explorada textualmente, tanto do ponto de vista matemático como do ponto de vista conceitual e é ponto positivo e de destaque do produto educacional.

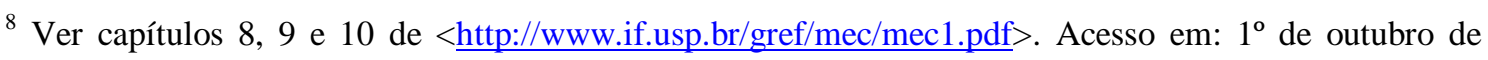
2015.
} 
Com relação à proximidade ou discrepância (inovação) com outras obras didáticas, os sujeitos dizem o seguinte:

“É possível comparar esta obra com outras, no sentido de esquematizar as vantagens $e$ as desvantagens de cada autor relativamente ao tema. Acredito que essa proposta de ensino encontra-se alinhada à visão educacional da aprendizagem por descoberta (inquiry) bem como ao construtivismo e as teorias cognitivistas, mostrando-se alternativa ao método tradicional de ensino onde o excesso de formalismo matemático e a centralização das informações no docente afasta dos alunos o interesse pela Física”. (Sujeito A).

“Acredito que a forma apresentada no roteiro é sim inovadora, pois articula o desenvolvimento matemático e sua interpretação com a contextualização do assunto. Cada passagem é comentada, interpretada e contextualizada. A conexão com outros assuntos do conteúdo de Física (tais como Gravitação Universal) demonstra o caráter de construção e evolução da Ciência. Conheço poucos materiais com tal capacidade." (Sujeito C).

De alguma forma, como já comentado no referencial teórico, a linha de desenvolvimento de ensino e aprendizagem subjacente à proposta didática de ensino da CMA elaborada junto a este trabalho, apoia-se na teoria da aprendizagem significativa de David Ausubel, como bem percebe o sujeito D em seu comentário.

“(...) mas, se os alunos não tiverem os conhecimentos prévios dos conteúdos citados acima, o material se torna inviável em termos da compreensão matemática, pois aos mesmos faltam subsunçores." (Sujeito D).

Porém, é interessante e oportuno - além de promissor - verificar o alinhamento de minha proposta de ensino à visão educacional das aprendizagens por descoberta, no ponto de vista do sujeito A. O inquiry recebe diferentes conceituações, tais como: ensino por descoberta, aprendizagem por projetos, atividades investigativas. Com toda a segurança, as atividades experimentais sugeridas pela proposta pedagógica exploram esse arquétipo educacional. 
A perspectiva do ensino com base na investigação possibilita o aprimoramento do raciocínio e das habilidades cognitivas dos alunos, e também a cooperação entre eles, além de possibilitar que compreendam a natureza do trabalho científico. (ZÔMPERO; LABURÚ, 2011, p. 68).

Quanto à viabilidade na utilização do material para o ensino médio, as opiniões dos sujeitos de pesquisa são bem diversificadas. Iniciando pela avaliação do sujeito B:

“O grande problema desse tópico é o fato de não ser cobrado na UnB. Além do enorme currículo de física que já existe, além do fato de não ser de grande utilidade prática para o cotidiano dos alunos." (Sujeito B).

Na realidade, o assunto Momento Angular é conteúdo frequentemente abordado pelo vestibular da Universidade de Brasília (UnB), visto que boa parte das questões (exercícios) propostas ao final do texto didático foi retirada desse concurso. Também discordo a respeito da afirmação do sujeito B ao asseverar que os conteúdos subjacentes à proposta didática não têm grande utilidade prática no cotidiano dos alunos. Atesto, e o texto didático ilustra ricamente minha assertividade, que a conservação do momento angular, que é uma das leis máximas da física e da natureza, sempre esteve presente diariamente, não só na vida de cada um, como em todo o universo conhecido. Em total acordo à opinião de Silva (2012), o conteúdo da CMA possui igual potencial de contextualização ou ainda maior que outros assuntos costumeiramente preferidos pelos livros didáticos, dada sua representatividade em diversos fenômenos físicos. Apesar disso, ainda parece não haver motivos aparentes a sua não inclusão no currículo médio. Especulo que seja apenas uma questão de tradição histórica. Boa parte dos conteúdos hoje presentes nos livros escolares são os mesmos das primeiras transposições didáticas para o meio escolar. Com poucas exceções, estes conteúdos permanecem estanques e acostumou-se a tratar sempre dos mesmos assuntos. A solução, portanto, subjaz à ousadia da escola e/ou do professor de aventurar-se a ensinar outros temas de igual relevância ou, até mesmo, de maior interesse no espaço destinado ao currículo diversificado da educação básica, por exemplo. Uso o termo "ousadia" ao procurar apoio na Lei de Diretrizes e Bases da Educação Nacional (Lei Nº 9394/96) que assevera a liberdade de organização das escolas na composição desta parte diversificada: 
Os currículos do ensino fundamental e médio devem ter uma base nacional comum, a ser complementada, em cada sistema de ensino e estabelecimento escolar, por uma parte diversificada, exigida pelas características regionais e locais da sociedade, da cultura, da economia e da clientela.

Por outro lado, e agora em acordo à apreciação do sujeito B, tenho igual convicção que o conteúdo de física, estudado no ensino médio, é demasiadamente extenso. Parecerá estranho ao leitor que, com minha proposta pedagógica, acrescentarse-á "mais um" conteúdo a ser estudado. Entretanto, acredito que essa excessiva carga de conteúdos - que não acontece com a física, mas em todos os outros componentes curriculares - dá-se em função dos exames vestibulares, como se estes tivessem de orientar o currículo das escolas de ensino médio do país. Sob outra perspectiva, "o aprimoramento do educando como pessoa humana, incluindo a formação ética e o desenvolvimento da autonomia intelectual e do pensamento crítico", de acordo com a Lei de Diretrizes e Bases da Educação Nacional (Lei N 9394/96), deveria ser a razão maior para seleção dos componentes curriculares de uma educação básica. De acordo com o volume 2 do documento Orientações Curriculares para o Ensino Médio: Ciências da Natureza, Matemática e suas Tecnologias:

E quem se pretende formar com o ensino da Física? Partimos da premissa de que no ensino médio não se pretende formar físicos. $\mathrm{O}$ ensino dessa disciplina destina-se principalmente àqueles que não serão físicos e terão na escola uma das poucas oportunidades de acesso formal a esse conhecimento. Há de se reconhecer, então, dois aspectos do ensino da Física na escola: a Física como cultura e como possibilidade de compreensão do mundo. (BRASIL, 2006, p. 53)

Assim, parto em defesa da autonomia do professor no que diz respeito à seleção dos conteúdos. Esta deve se sujeitar às diretrizes e orientações sobejamente discutidas entre os educadores, referenciadas por conselhos de educação e legitimadas por leis e normativas; ao contrário daquilo que se pratica quase que por uma tradição funcionalista, que é o de atender a uma formação voltada exclusivamente ao instrumentalismo dos alunos para lograr êxito numa prova de vestibular. Não seria o caso de debater isso aqui, já que foge as meus objetivos, mas seria interessante perguntar se os conteúdos aprendidos não deveriam atender a perspectiva de formar culturalmente os sujeitos ao invés de exclusivamente prepará-los para um exame. 
Considero extremamente interessante e pertinente o comentário do sujeito $\mathrm{C}$ a seguir a respeito da viabilidade e relevância ou não na utilização da proposta didática para o ensino médio.

“(...) penso que o assunto é relevante para o EM, porém não mais que outros que já não costumam ser ensinados por falta de tempo e condições. Assim, apesar da proposta ser excelente, ela apenas destaca as dificuldades presentes no ensino de Física no EM." (Sujeito C).

Entretanto, ao considerar tais dificuldades em função do pouco tempo e demais condições (de trabalho?), seria necessário entrar num debate de natureza política e organizacional da educação de nosso país. Tal debate foge ao escopo deste trabalho, embora reconheça que suas observações incidam de fato sobre a aplicação da proposta. E o fazem por incidir não só no ensino da física, como sobre quaisquer outros componentes curriculares (disciplinas ensinadas nas escolas) constitutivos do ensino médio do país. A meu ver, estes componentes estão dispersos, em demasia, e com igual exagero de conteúdos. Em suma, há "matérias" demais!

Já o sujeito A, considera que o material despertaria maior interesse por alunos que já se mostrassem inclinados aos temas da física.

“É possível o magistério do tema no Ensino Médio (EM), no entanto, devido ao nível de abstração eu trabalharia o assunto em turmas pequenas e com os estudantes mais apaixonados pela Física. Não é a matemática que é avançada, mas os raciocínios desenvolvidos são abstratos." (Sujeito A).

Confesso não ter ficado claro para mim, a que nível de abstração o sujeito A se refere. Sobre sua opção de aplicar o material em turmas pequenas "e" com estudantes apaixonados pela física, entendo que na opinião do sujeito $\mathrm{A}$, minha proposta educacional já tem endereço certo e não convém ser compartilhada com outros alunos que pouco interesse têm pelo componente curricular que "leciono(amos)". Não era essa a minha intenção inicial ao elaborar a proposta didática, mas é ponto importante a considerar. Imaginar a possibilidade de dar aulas de um determinado assunto apenas para alunos interessados é o sonho de todo professor. Mas, ao considerar tal 
possibilidade, não consigo encontrar diferenças entre o estudo desse assunto como de qualquer outro, como bem apontou o sujeito $\mathrm{C}$, anteriormente.

O sujeito D, considera a aplicação do material possível desde que garantidos os pré-requisitos exigidos pela proposta.

"Pela forma lúdica que foi apresentado o material, vejo que algumas coisas podem ser utilizadas com uma boa transposição didática para o ensino médio para que os alunos compreendam o conceito de momento angular e conservação do momento angular. Pois dependendo da escola, os alunos já sabem: conceito leis de Newton, movimento circular, resultante centrípeta, conservação de energia mecânica, torque, momento linear, sendo o material um bom recurso para facilitar a compreensão das analogias matemáticas proposta para o entendimento de momento angular e conservação do momento angular." (Sujeito D).

De fato estes são os cuidados a serem tomados pelo professor que teria interesse de aproveitar o material, como já foi mencionado na seção 3.5.

\subsection{Sobre a natureza de a proposta ter características de roteiro fechado e com pouco espaço de intervenção do professor.}

Todo o texto didático foi elaborado como um roteiro orientador narrado em prosa. Não foi construído nos mesmos moldes de um Manual do Professor, um compêndio que acompanha muitos livros didáticos e contém orientações e sugestões dos autores para a utilização do material. Minha preocupação residia na hipótese do professor sentir-se "preso" a um esquema pronto, não sujeito a adaptações, modificações ou intervenções. Logo, esse eixo temático objetivou verificar se o produto apresentado nesse formato incomodava. E quanto às adaptações e intervenções, quais e de que forma seriam realizadas?

$\mathrm{Na}$ opinião de dois dos sujeitos da pesquisa, a roteirização dos procedimentos e desenvolvimento das ideias não incomoda e ainda facilita a exequibilidade da proposta em suas características originais. 
"O roteiro facilita a aplicação do conteúdo, garantindo maior eficiência no mesmo. Além de dificultar ações que distorcem a proposta original." (Sujeito B).

"O fato de apresentar-se como roteiro não incomodou. Os roteiros são importantes no encadeamento de ideias de cada situação em destaque." (Sujeito A).

Reitero que minha preocupação quanto ao formato escolhido na elaboração da proposta não era tornar o seu uso algo inflexível. O que menos queria é que a sua leitura fosse seguida como uma "receita de bolo". Diferentemente dos sujeitos A e B, que entenderam útil esta característica, minha inquietação é observada e criticada pelo sujeito D e pelo sujeito $\mathrm{C}$, embora, neste último, o seja em contexto diferente.

"Sim, pois para se ensinar não existem regras. Vejo (...) um melhor nome: sequência didática, (...) que pode ser alterada de acordo com a realidade dos alunos que participam do processo de aprendizagem." (Sujeito D).

"Apresenta-se como um roteiro fechado instruindo o caminho do professor na construção do conhecimento "Conservação do Momento Angular". (...) o roteiro fechado se adéqua a uma realidade escolar que eu não possuo. Ele não se mostra adaptável/ajustável, pois não me indica como aplicá-lo em uma situação mais próxima da minha realidade." (Sujeito $C$ ).

De fato, parece pertinente e apropriado repensar acerca de outras possibilidades que não apenas às salas de aulas da $1^{\mathrm{a}}$ série do ensino médio para aplicação de minha proposta pedagógica.

Na mesma linha da aplicabilidade frisada pelo sujeito $\mathrm{C}$ acima, como os sujeitos de pesquisa poderiam intervir ou modificar as ideias originais do produto em análise? Vejamos o que diz o sujeito A.

"Os pontos de intervenção seriam aqueles onde a correspondência entre determinada situação e a variável contida numa equação, exigiriam a abstração que muitas vezes os estudantes têm de maneira limitada. Como exemplo, eu explicaria com o objeto na mão (no caso da experiência 1) cada passo a passo entre o que diz as equações e o que se vê no sistema em estudo, no caso, a massa girando amarrada no barbante." (Sujeito A). 
Também foi sugerido pelo sujeito A, a inserção de diagramas de corpo livre no material analisado. Segundo o mesmo, a "visualização" das forças atuantes na borracha auxiliaria na compreensão da correspondência que existe entre o modelo matemático representado via equações algébricas - variáveis como literais - e a percepção física do fenômeno associado à experiência realizada. Outra observação oportuna foi assinalar que a borracha não pode girar num plano horizontal - paralelo ao solo - nas condições em que foi proposta a realização da experiência. Trata-se de uma analogia com problemas que envolvem um objeto girando sobre uma mesa sem atrito, amarrado a outro que se encontra suspenso pela corda e que passa através de um orifício da mesa, como mostra a figura 4.1 .

Figura 4.1. Objeto suspenso por outro ao percorrer trajetória circular sobre uma mesa.

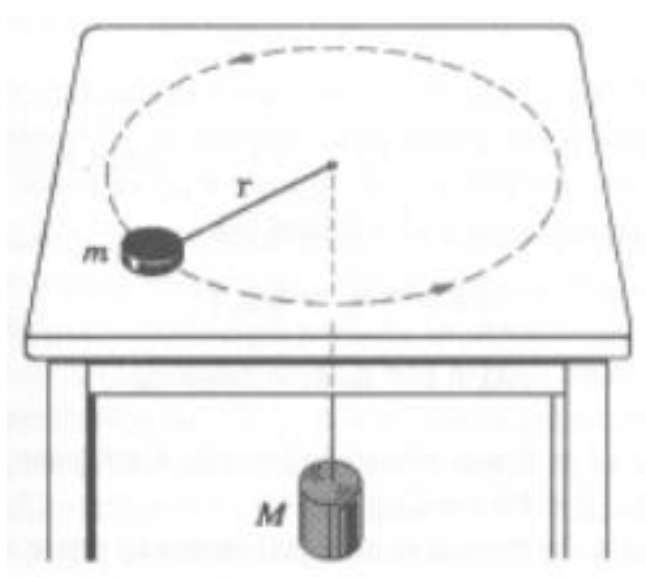

Fonte: RESNICK, HALLIDAY, KRANE, Física, v. 1, 4ª ed., p. 119.

Digo oportuna, pois a situação acima explora a conservação do momento angular de forma equivalente àquela sugerida pela terceira modificação de variável na primeira experiência com a borracha. Considerando o fio que liga os objetos de massa $m$ e $M$ como inextensível (sempre de mesmo comprimento), para cada altura em que se posiciona o corpo que está suspenso, haverá uma velocidade específica para o objeto que gira sobre a mesa, pois o raio $r$ da trajetória circular também irá se modificar.

Voltando ao sujeito C: 
"Eu faria, para minha realidade, uma abordagem puramente conceitual, buscando aproveitar mais as atividades experimentais propostas e os exemplos citados. Não apresentaria a estrutura matemática, apesar de simplificada, uma vez que não conseguiria encontrar justificativas (livro didático, vestibular, exames externos) para tal (...).” (Sujeito C).

De fato, o produto educacional seria útil como material de referência, não como um roteiro prescrito. Isso abre outras possibilidades para meu produto pedagógico ao fugir do estigma de ser encarado apenas com um roteiro de aula. Sob esse julgo, pareceme que, no mínimo, o material serviria para fomentar ideias e direcionamentos ao professor que tem acesso a ele. Dessa forma, o professor poderia enriquecer suas aulas valendo-se das experiências e os exemplos abordados pela proposta pedagógica. Vê-se que no caso do sujeito $\mathrm{C}$, ele abdica da estruturação matemática na qual se apoiam diversos dos argumentos desenvolvidos na proposta; em contrapartida, encontra utilidade tanto na parte experimental e exemplos quanto nos aspectos conceituais igualmente explorados ao longo da proposta pedagógica.

Estas observações engendradas pelas experiências geram questões problematizadoras segundo a visão do sujeito $D$, conquanto reconheça que a "matematização" da teoria auxilie na melhor compreensão dos movimentos de rotação.

“(...) esse material poderia ser utilizado como um material problematizador, como por exemplo, abordando as teorias de aprendizagem de Paulo Freire e Barchelard. (...) o aluno gera dúvidas, para que mais tarde possa buscar respostas de forma independente, sendo o professor, somente um mero mediador. (...) acredito que depois que a teoria fosse matematizada, o aluno teria uma melhor compreensão dos fenômenos de rotação." (Sujeito D).

Relativizando o discurso do sujeito D como já expus no capítulo 2, de nenhuma forma considero o professor um mero mediador do processo educacional. Isso me soa pejorativo e minimiza o que ainda resta de prestígio em nossa profissão. Se assim o fosse, que sentido há nessa minha qualificação? Tornar-me-ei um especialista para ser um mero mediador? O professor é peça fundamental no processo de ensinoaprendizagem, sem o qual a instituição escola não teria sentido existencial. Afirmo 
tacitamente que é ingênuo acreditar que um aluno "gerará dúvidas" sobre quaisquer assuntos apresentados em aula. Mais ainda, que ele será capaz de descobrir tudo por si próprio. Para se descobrir é preciso orientar o olhar para o que será descoberto. E tal orientação é de dever e responsabilidade do professor. Perdoe-me o leitor pela verbosidade desmedida e/ou divagação ainda que pertinente do ponto de vista pedagógico acerca dos comentários do sujeito D.

\subsection{Sobre as motivações do professor com relação ao uso da proposta educacional em face às possíveis dificuldades em aplicá- lo em sala de aula ou equivalente.}

Neste último ponto, o que "quero saber" é se de fato o sujeito arriscar-se-ia a implementar a proposta em sua realidade escolar. Uso o verbo "arriscar" porque me interessa identificar que dificuldades ele acredita existirem inerentes à proposta de ensino. Como minha motivação era produzir algo que enriquecesse o currículo da física nas escolas públicas, pergunto se, nesse contexto, o produto educacional faria sentido ou não. Se não, em que outros meios ou contextos meu produto melhor se ajusta?

Parece não haver motivações para o sujeito B.

"Na verdade não há motivação devido ao fato de que nosso aluno não se interessa por quase nenhum tópico do curso de física. (...) um tópico mais complexo evidenciaria isso. (...) talvez, caso o Brasil criasse cursos direcionados, um tópico como esse seria mais bem aproveitado, assim como boa parte dos conteúdos estudados hoje." (Sujeito $B)$.

Cabem, nessas ponderações finais do sujeito B, as mesmas advertências que teci na seção anterior sobre pretensas salas de aula compostas apenas de alunos interessados em aprender física. $\mathrm{O}$ argumento acima, se considerado a sério, destroi não só a minha tentativa de sugerir ensinar a lei de conservação do momento angular no ensino médio como inclusive boa parte dos demais conteúdos que jazem presentes nos currículos atuais. Conquanto, convém apontar, que o motivo "desmotivador" apresentado acima pelo sujeito $\mathrm{B}$ coaduna-se à terceira causa que depunha contra a eficácia do ensino da CMA na pesquisa de Silva (2012), qual seja o crescente desinteresse dos estudantes em aprender conteúdos de Física na escola. Igualmente, convém chamar a atenção, que tal 
desinteresse por parte do alunado não é específico ao conteúdo de minha proposta pedagógica senão aos conteúdos da Física de forma geral. Mas não convém, neste momento específico, refletir sobre as razões que desmotivam nossos educandos.

Em conjunto, as opiniões dos demais sujeitos da pesquisa.

"O material em análise seria ideal para grupos de pequenos estudantes a fim de criar discussões acerca do assunto e logo em seguida abrir debate sobre a matéria em questão para toda a turma. A dificuldade que observo seria em dotar de significado aos estudantes as informações de cada passo a passo dos experimentos com as relações entre variáveis nas equações de descrição do fenômeno. Acredito que o material em estudo pode ser um aliado no ensino do tema nas escolas públicas no ensino regular e nas escolas particulares. Já na sua utilização em turmas de Educação de Jovens e Adultos (EJA), acredito que o elevado nível de abstração e o apelo matemático na análise de variáveis nas equações poderia ser algo enfadonho para maioria." (Sujeito A).

"Se o material fizesse parte de um compêndio maior, escrito nessa perspectiva, e adotado por minha escola, sentiria motivado a usá-lo. Caso houvesse um momento extra para aplicá-lo, com alunos mais interessados, também o utilizaria. Não conheço a realidade da SEEDF, mas creio que seja próxima da minha no que tange a baixa quantidade de aulas destinadas para Física, os calendários apertados, a falta de embasamento matemático dos educandos e a cobrança de melhora nos indicadores educacionais (ENEM, Prova Brasil etc). Nesse contexto, e como já exposto, não me sentiria capaz de aplicar o material com o enfoque fornecido pelo autor. Talvez numa situação de cursinho pré-vestibular, não sei. Ainda assim a noosfera iria afetar demais a escolha da minha ação profissional e a seleção desse conteúdo.” (Sujeito C).

"Sim, numa escola que tem, por exemplo, quatro aulas de física por semana. (...) o professor pode usar como um material de apoio, ou seja, como sequência didática, mas numa escola com poucas aulas seria muito complicado como é o caso na SEEDF. (...) destaco os seguintes fatores relevantes para o uso do material: o número de aulas, a falta de conhecimento prévio dos alunos para abordar tal assunto por ser bastante 
complexo, mesmo tendo a parte experimental de forma lúdica, como sugere o material." (Sujeito D).

Há dois pontos em especial a considerar nesses comentários finais dos sujeitos A, C e D. O primeiro se refere às desconfianças, incertezas e resignações dos sujeitos frente às políticas educacionais aplicadas à escola pública. Reaparecem, uma vez mais, os dois primeiros motivos relativos à ineficiência do ensino da CMA apontados pelos professores das escolas públicas estaduais do município de Maringá - PR por intermédio dos questionários aplicados na pesquisa de Silva (2012): escassez de tempo, ausência de infraestrutura e condições de trabalho adequadas. Parece-me que não há como ignorar essa variável e comentarei mais a respeito - como já o fiz na seção 1.2 - e de forma muito pessoal, na conclusão deste trabalho. O segundo é de cunho pedagógico e se refere às necessidades de pré-requisitos conceituais, principalmente, de domínio matemático e que têm relação direta com os caminhos por mim escolhidos na configuração da proposta de ensino.

Neste sentido, um dos aspectos que acredito valer a pena ser comentado neste desfecho é a respeito da forma pela qual avançam os raciocínios físicos explorados ao longo do material. Tais raciocínios foram propositalmente elaborados e ancorados em desenvolvimentos matemáticos de maneira que as equações matemáticas relacionadas a eles sejam vistas também como equações físicas. Concordo em muito que a forma com a qual são tratadas as equações matemáticas em alguns livros didáticos e afins pode se constituir num grande obstáculo pedagógico no aprendizado da física. Porém, como já argumentei no capítulo anterior, afirmo resolutamente que sem a matemática, não há física no sentido integral do termo. Se um aluno me pergunta o que é a física, respondo que é a ciência que estuda a natureza fazendo-se valer de modelos matemáticos que buscam compreendê-la devido à existência de regularidades. No mínimo, a física tem o papel de descrever os fenômenos naturais, permitindo-nos falar de previsões científicas sobre o comportamento da natureza, sua conceituação e quantificação por grandezas físicas. As equações matemáticas são importantes para a física. Amplio: a matemática como um todo é de fundamental importância para a física, para o ensino da física e para o desenvolvimento intelectual de todo ser que se pretende mais inteligente. A meu ver, não deveriam ser necessários muitos argumentos para convencer as pessoas sobre a importância da matemática em nossas vidas. Foge do escopo deste trabalho expor motivos para defender a dimensão da matemática que, em meu ponto de vista, é 
decididamente da mais alta relevância para o indivíduo e a sociedade. Neste trabalho, cabe-me defender meu aporte pedagógico, e rogo às asserções de Anjos, Salehices e Moreira (2015), que asseveram que "as equações matemáticas são imprescindíveis, entretanto não podem ser priorizadas em detrimento à fenomenologia da matéria em estudo e suas implicações conceituais". Como bem observam os sujeitos de minha pesquisa, houve preocupação na integridade da proposta pedagógica de manter a matemática acessível ao nível de conhecimento e abstrações "comuns" dos alunos de ensino médio. Isso é bem observado ao longo de todo este capítulo nos comentários retirados das entrevistas realizadas com os sujeitos da pesquisa. Em especial, transcrevo mais uma vez o comentário do sujeito $\mathrm{C}$ a seguir:

“(...) a forma apresentada no roteiro é sim inovadora, pois articula o desenvolvimento matemático e sua interpretação com a contextualização do assunto. Cada passagem é comentada, interpretada e contextualizada. A conexão com outros assuntos do conteúdo de Física (tais como Gravitação Universal) demonstra o caráter de construção e evolução da Ciência. Conheço poucos materiais com tal capacidade." (Sujeito C).

Retomo a afirmação acima, pois trata-se do mesmo sujeito $\mathrm{C}$ que abdica do uso da matemática para adaptar o uso do material em sua realidade local:

"Eu faria, para minha realidade, uma abordagem puramente conceitual, buscando aproveitar mais as atividades experimentais propostas e os exemplos citados. Não apresentaria a estrutura matemática, apesar de simplificada, uma vez que não conseguiria encontrar justificativas (livro didático, vestibular, exames externos) para tal (...)." (Sujeito C).

Perceba o leitor, que não há desmerecimento do uso da matemática e, ao mesmo tempo, a valorização dos conceitos associadas a ela - embora de forma velada - ao se optar por uma abordagem puramente qualitativa. O material produzido a partir desta pesquisa parece atender ambos os aspectos - conceitual e operacional-matemática para o sujeito $\mathrm{C}$.

Nas palavras de Anjos, Salehices e Moreira (2015, p. 312):

Em geral, o ensino das Ciências Naturais é pautado no conhecimento de leis e princípios, conceitos e significados, fórmulas e equações, 
descontextualizado e desconectado da realidade do aprendiz que, por sua vez, é agente passivo no processo. Particularmente em Física, onde o ensino é desenvolvido com base no uso de fórmulas e equações, além de leis, princípios e conceitos isolados, a aprendizagem, por consequência, ocorre de forma mecânica, estéril e desvinculada do mundo vivenciado pelo estudante, proporcionandolhe condições que, na maioria das vezes, apenas lhe permite repetir os enunciados das leis sem entender os significados dos conceitos e resolver mecanicamente, com o uso das expressões matemáticas, os problemas propostos no livro texto.

Foi igualmente pensando minimizar os descompassos evidenciados acima que minha proposta pedagógica foi elaborada.

\section{Considerações finais e perspectivas futuras}

O trabalho ora apresentado teve como objetivo identificar como o conteúdo da conservação do momento angular (CMA) tem sido ofertado em livros didático de física para o ensino médio de escolas públicas brasileiras, tomando como recorte de análise os livros que constam no Plano Nacional do Livro Didático (PNLD) de 2015. Na esteira desse objetivo, acompanhou-me a produção de uma proposta didática referente a este conteúdo e cuja idealização já se dera há muito. Como recurso metodológico de investigação, submeti o mesmo à análise e avaliação de professores de física com experiência no magistério da educação básica em escolas públicas e privadas.

As pesquisas em torno de análise dos livros didáticos evidenciaram severa ausência ou pouca difusão do conteúdo de CMA. Entretanto, os poucos livros que abordam de forma mais aguda o conteúdo o fazem segundo perspectivas pedagógicas interessantes no que diz respeito à contextualização e inferências com o cotidiano dos alunos. Tais abordagens somadas aos estudos em torno de pesquisas educacionais que envolvia o ensino de CMA bem como as experiências pedagógicas ao longo de minha trajetória no magistério foram determinantes para a elaboração de uma proposta pedagógica em CMA, materializada em produto educacional incorporado ao trabalho e razão maior da pesquisa.

A proposta educacional procurou manter uma narrativa fluida, de fácil compreensão, orientando o professor de forma pormenorizada o ensino de CMA no âmbito do ensino médio por meio de várias situações do cotidiano exemplificadas por meio de experimentos e explorando o instrumental matemático associado. Coadunou-se à proposta a teoria da aprendizagem significativa de David Ausubel, cujas ideias pedagógicas foram tomadas como referencial teórico. 
De forma geral, a análise e avaliação crítica dos professores que participaram do estudo resultaram em debate que possibilitou a retomada de estudos realizados ao longo do processo de investigação. Segundo eles, existe adequação da proposta ao referencial teórico pedagógico da aprendizagem significativa, sobretudo no que corresponde a necessidade de pré-requisitos conceituais de natureza matemática como condicionantes do êxito do material. O conteúdo e a forma foram bastante elogiados, quando se enfatizou características de contextualização de fenômenos físicos e a realidade do cotidiano dos alunos, ponto forte da proposta. A maior parte dos comentários desses professores enalteceu o produto e a crítica recaiu, quase que consensualmente, sobre a viabilidade de operacionalização dela em face ao contexto da escola pública do Distrito Federal.

Com efeito, salvo estar sendo um tanto quanto pessimista, a conclusão final a que cheguei é que meu produto, nos termos que se apresenta, dificilmente pode ser aplicado, friso, atualmente. Convém destacar, que a negativa ao seu potencial de aplicação, deve observar o contexto da escola pública do DF, lugar da experiência da maioria dos professores entrevistados. Não porque tenha sido mal escrito ou contenha incorreções, mas porque a situação real das escolas não apresenta condições de incentivo à prática e valorização dos conteúdos. Número reduzido de aulas e desorganização na distribuição das cargas horárias entre as disciplinas são outros dois reveses.

Em consequência das entrevistas com os professores que participaram de minha pesquisa, pude ter muita clareza sobre as dificuldades da utilização do texto didático em sala de aula na forma atual em que se apresenta. Revisitando meu memorial entregue na fase de seleção, vejo que cumpri minimamente o que fora prometido, elaborando um material que, sustentado por assuntos e instrumentais matemáticos socializados na educação básica, permitisse que os alunos tivessem condições de apropriar-se de um campo da física abrangente, prático e perceptível na vida comum do dia a dia. Sua aplicação, no entanto, esbarra na falta de infraestrutura escolar seja do ponto de vista organizacional, político ou pedagógico. Concluo que para ser bem aproveitado, em face às condições presentes, o material precisa chegar às mãos do professor interessado em aplicá-lo logo ao início do ano letivo, de modo que ele possa planejar-se para utilizá-lo ao fim do curso como uma grande síntese de muitos dos conteúdos estudados ao longo do ano. Isso não soa mal, mas parece-me preocupante. Se algum dos conteúdos permeados pela minha proposta didática não for contemplado, comprometerá, ao menos 
em parte, a integridade e objetivos almejados de sua aplicação. Não bastasse, como foi observado não só por mim como pelos sujeitos da presente pesquisa, sem o mínimo de desenvoltura em matemática básica, a proposta é ininteligível se seguida em sua total essência metodológica. Repare o leitor como as estruturas cognitivas nomeadas por Ausubel de subsunçores subjazem recorrentes no processo de ensino e aprendizagem e tornam-se fatores críticos quanto ao sucesso ou fracasso desta minha empreitada.

Penso diante de tais circunstâncias, que perspectivas futuras possam ser almejadas via modificações e adaptações das ideias e do texto original. Por exemplo, retirando alguns conteúdos ou desvinculando-os de temas tomados como pré-requisitos, ou mesmo encontrando outra forma de avançar nos raciocínios físicos sem a necessidade de um correspondente matemático. Como o leitor pode se recordar, pessoalmente não estou inclinado a ensinar física no âmbito escolar sem o aporte matemático conjugado a ela. Talvez o material possa ser aplicado da forma como está em alguma escola particular, onde professores são pressionados a cumprirem conteúdos empurrando-os "goela abaixo" de seus alunos. Infelizmente, todas as possibilidades levantadas descaracterizam minha proposta de ensino da CMA em sua forma original.

Alguém diria que pareço reviver pensamentos corriqueiros experimentados por muitos colegas de profissão e em contextos que nada têm a ver com o ensino da lei de conservação do momento angular. Mas, professor como eles, ainda acredito que condições melhores virão e nos sentiremos satisfeitos pelo simples fato de termos compartilhado algo que nos era interessante.

Posto isso, torcerei e esforçar-me-ei para que condições mais adequadas coroem meu desejo de socializar uma forma de ensinar um conteúdo de física que entendo pertinente e que não pode (ou não deveria) ser negligenciado aos alunos da educação básica. 


\section{Referências}

ANJOS, A. J. S.; SAHELICES, C. C.; MOREIRA, M. A. As equações matemáticas no ensino de física: uma análise de conteúdos em livros didáticos de física. Revista Electrónica de Enseñanza de las Ciencias, v. 14, n.3, p.312-325, 2015.

ARRUDA, S. M.; VILLANI, A. Mudança conceitual no ensino de ciências. Caderno Catarinense de Ensino de Física, Santa Catarina, v.11, n2: p.88-99, agosto, 1994.

BRASIL. Ciências da natureza, matemática e suas tecnologias / Secretaria de Educação Básica. - Brasília: Ministério da Educação, Secretaria de Educação Básica, 2006.

Guia de livros didáticos: PNLD 2015: física: ensino médio. Brasília: Ministério da Educação, Secretaria de Educação Básica, 2014.

BROCKINGTON, G; PIETROCOLA, M. Serão as regras da transposição didática aplicáveis aos conceitos de física moderna? Investigações em Ensino de Ciências, v.10, n.3, p.387-404, 2005.

CARVALHO, O.; VILLANI, A. Aprendizagem dos princípios de conservação em entrevistas didáticas. Investigações em Ensino de Ciências, Porto Alegre, v.1, n.1, p.76-94, março, 1996.

FREITAG, B. et al. O livro didático em questão. $2^{\text {a }}$ ed. São Paulo: Cortez, 1993.

GASPAR, A. Física 1: mecânica. 2a edição. São Paulo: Editora Ática, 2010. v. 1.

GIL, A, C. Como elaborar projetos de pesquisa. São Paulo: Atlas, 2002.

GREF (Grupo de Reelaboração do Ensino de Física). Física 1: mecânica. $7^{\mathrm{a}}$ edição. São Paulo: Edusp, 2001.

HALLIDAY, D; RESNICK, R. Fundamentos da Física 1. $1^{\text {a }}$ edição. Rio de Janeiro: LTC - Livros Técnicos e Científicos Ed., 1991. v. 1.

HECKLER, V. Uso de simuladores e imagens como ferramentas auxiliares no ensino/aprendizagem de ótica. 228f. Dissertação. (Mestrado Profissional em Ensino de Física) - Universidade Federal do Rio Grande do Sul, UFRGS, Porto Alegre, 2004.

KANTOR, C. A.; PAOLIELlO JÚNIOR, L. A.; MENEZES, L. C.; BONETTI, M. C.; CANATA JÚNIOR, O.; ALVES, V. M. Quanta Física. 2a edição. São Paulo: Pearson, 2013. v. 1.

MORALES, C. A. C. Enseñanza de la conservación del momento angular por medio de la construcción de prototipos y la aprendizaje basado em proyectos. Latin-American Journal of Physics Education, v.3, n.2, p.427-432, 2009a. 
Prototipo para la Enseñanza de la Dinámica Rotacional (Conservación del Momento Angular). Latin-American Journal of Physics Education, v.3, n.2, p.446448, $2009 b$.

MOREIRA, M. A. Teorias de Aprendizagem. São Paulo: EPU - Editora Pedagógica e Universitária Ltda, 1999.

A teoria da aprendizagem significativa. Porto Alegre: Instituto de Física, UFRGS, 2009.

Aprendizagem significativa: um conceito subjacente. Aprendizagem

Significativa em Revista. v.1, n.3, p.25-46, 2011

MINAYO, M. C. S. O desafio do conhecimento: pesquisa qualitativa em saúde. São Paulo: Hucitec, 2007.

RESNICK, R.; HALLIDAY, D.; KRANE, K. S. Física. 4a edição. Rio de Janeiro: LTC - Livros Técnicos e Científicos Ed., 1996. v. 1.

SILVA, L.C.B. O discurso dos professores de Física de Maringá e região sobre a abordagem do momento angular e do torque no Ensino Médio. 94f. Dissertação (Mestrado em Ensino de Ciências e Matemática) - Universidade Estadual de Maringá, UEM, Maringá, 2012.

TORRES, C. M. A.; FERRARO N. G.; SOARES P. A. T.; PENTEADO, P. C. M. Física Ciência e Tecnologia. $3^{\mathrm{a}}$ edição. São Paulo: Moderna, 2013. v. 1.

WÜRZ, G. Momento angular: uma proposta para o ensino de física, utilizando experimentos lúdicos. Cadernos de Publicações Acadêmicas, Florianópolis, v.1, n.1, p.71-79, 2012.

ZÔMPERO, A.F.; LABURÚ, C. E. Atividades investigativas no ensino de ciências: aspectos históricos e diferentes abordagens. Revista Ensaio. Belo Horizonte, v.13, n.3, p.67-80, set/dez, 2011. 